ORP-54002

Revision 0

\title{
Melter Throughput Enhancements for High-Iron HLW
}

Prepared for the U.S. Department of Energy

Assistant Secretary for Environmental Management

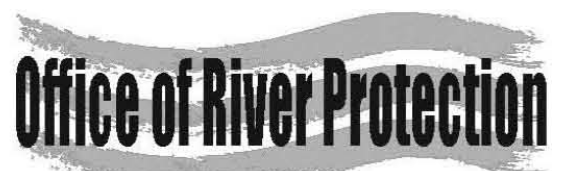

P.O. Box 450

Richland, Washington 99352 
ORP-54002

Revision 0

\section{Melter Throughput Enhancements for High-Iron HLW}

A. A. Kruger

Department of Energy - Office of River Protection

I. Joseph

The Catholic University of America

K. S. Matlack

The Catholic University of America

W. Kot

The Catholic University of America
H. Gan

The Catholic University of America

I. L. Pegg

The Catholic University of America

M. Chaudhuri

The Catholic University of America

Date Published

November 2012

Prepared for the U.S. Department of Energy Assistant Secretary for Environmental Management

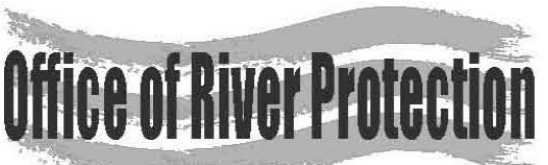

\section{P.O. Box 450}

Richland, Washington 99352

\section{APPROVED}

By Julia Raymer at 12:51 pm, Dec 26, 2012 
TRADEMARK DISCLAIMER

Reference herein to any specific commercial product, process, or service by tradename, trademark, manufacturer, or otherwise, does not necessarily constitute or imply its endorsement, recommendation, or favoring by the United States Government or any agency thereof or its contractors or subcontractors.

This report has been reproduced from the best available copy.

Printed in the United States of America 
VSL-12R2490-1

\title{
Final Report
}

\section{Melter Throughput Enhancements for High-Iron HLW}

\author{
prepared by
}

Keith S. Matlack, Hao Gan, Malabika Chaudhuri, Wing Kot, and Ian L. Pegg

Vitreous State Laboratory

The Catholic University of America

Washington, DC 20064

and

Innocent Joseph

EnergySolutions Federal EPC, Inc.

Columbia, MD 21046

for

Department of Energy

Office of River Protection

April 30, 2012

Rev. $0,5 / 31 / 12$ 
Document Title: $\quad$ Melter Throughput Enhancements for High-Iron HLW

Document Number

and Revision:

VSL-12R2490-1, Rev. A

Issue Date:

$5 / 31 / 12$

Performing Organization: Vitreous State Laboratory, The Catholic University of America

Test Plan: $\quad$ Melter Throughput Enhancements for High-Iron HLW, VSL-11T2490-1, Rev. 0

This report describes the results of testing specified by the above Test Plan. The work was performed in compliance with the quality assurance requirements specified in the Test Plan. Results required by the Test Plan are reported. The test results and this report have been reviewed for correctness, technical adequacy, completeness, and accuracy.

L. Pegg:
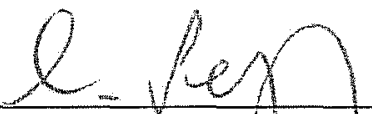

Date: $5 / 3 / 12$

VSL Program Director/Principal Iyvestigator

I. Joseph: Gmocrot taschb

Date: $-5 / 31 / 12$ 


\section{TABLE OF CONTENTS}

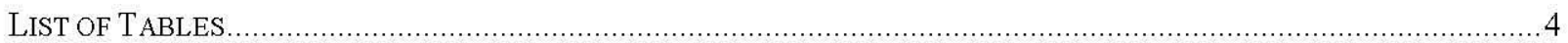

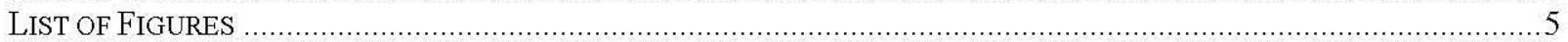

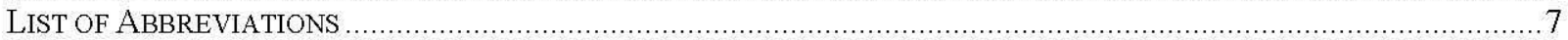

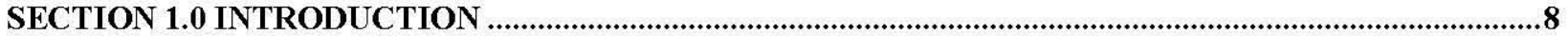

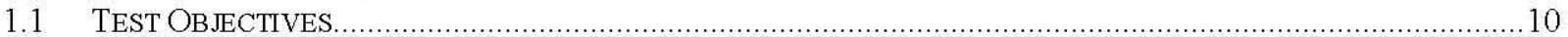

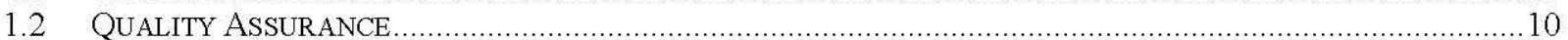

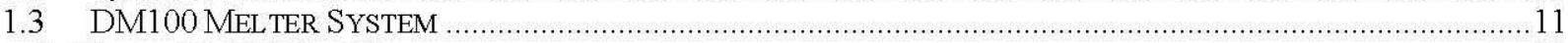

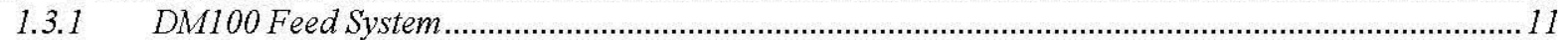

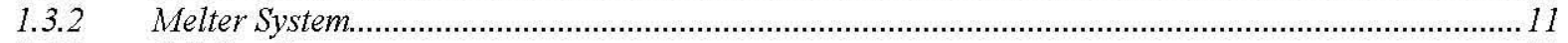

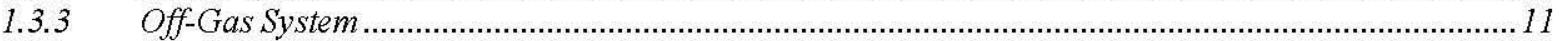

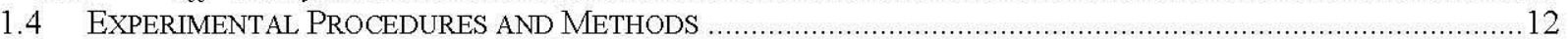

1.4.1 Feed Conversion by Vertical Gradient Furnace (VGF) Testing........................................................12

1.4.2 Feed Samples from Melter Tests........................................................................................... 12

1.4.3 Glass Product .................................................................................................................. 12

SECTION 2.0 DEVELOPMENT OF HIGH-IRON GLASS FOR C-106/AY-102 HLW.....................................15

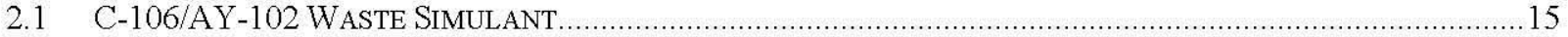

2.2 C-106/AY-102 BASELINE GLASS HLW04-09 AND FORMULATION CONSTRAINTS ......................................16

2.3 DEVELOPMENT OF HIGH-IRON HLW GLASS FOR C-106/AY-102 …..................................................16

2.3.1 Formulation at 37.1 wt\% Waste Loading ..................................................................................... 17

2.3.2 Formulation at 42 wt\% Waste Loading ……………....................................................................... 17

2.3.3 Formulation at $44 \mathrm{wt} \%$ Waste Loading ......................................................................................... 18

2.3.4 Formulations at 47 wt\% Waste Loading ....................................................................................18

2.3.5 Selection and Characterization of Candidate Formulation...........................................................19

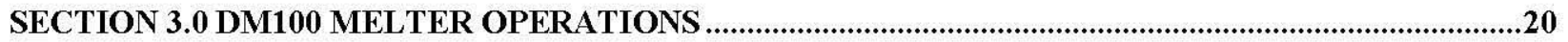

SECTION 4.0 FEED SAMPLE AND GLASS PRODUCT ANALYSIS.............................................................23

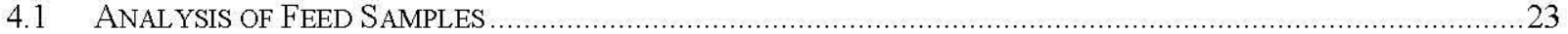

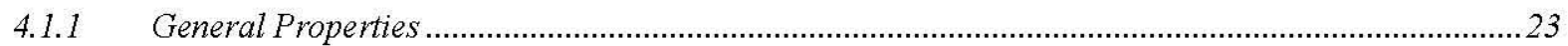

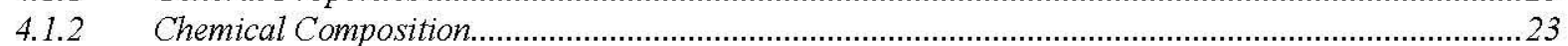

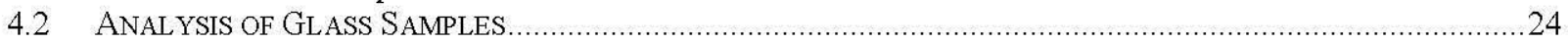

4.2.1 Compositional Analysis of Discharge and Dip Sample Glasses ......................................................24

4.2.2 Chemical Durability of Discharge Glasses ...................................................................................25

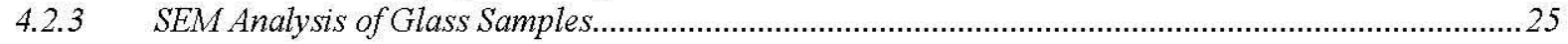

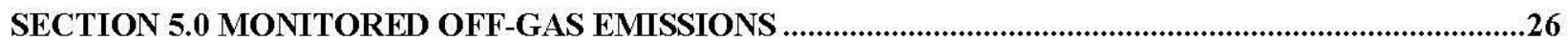

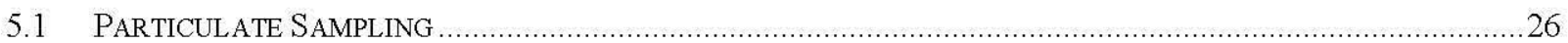

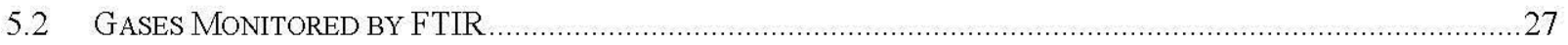

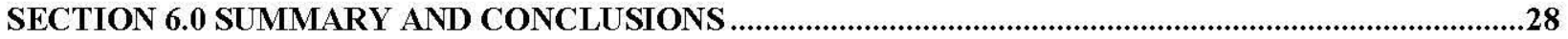

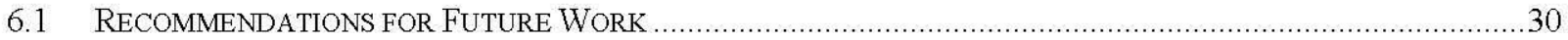

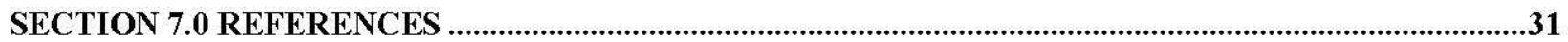




\section{List of Tables}

Actual Waste, AW-101 Cesium-Eluate, Blended Waste, and the

High-Iron HLW Simulant.

Table 2.2 Compositional Summary of the High-Iron HLW Simulant, Reference T-2

Glass HLW04-09, and Target Glass for Previous Melter Tests.

$\begin{array}{lll}\text { Table } 2.3 & \text { Blending Recipes for High Iron HLW Formulations. } & \text { T-3 }\end{array}$

Table 2.4 Target and XRF Analyzed Compositions of High Iron HLW Glasses $\quad$ T-4 for C-106/AY-102.

Table 2.5 Target and XRF Analyzed Compositions of Fused Slurry Feeds of High $\quad$ T-6

Table 2.6 Summary of Key Properties of High Iron HLW Formulations for $\quad$ T-8

Table 2.7 Ranking Definition for Feed Conversion after 30 Minutes in VGF. T-10

Table 2.8 Viscosity and Electrical Conductivity of Selected High Iron HLW Glasses T-10

$\begin{array}{lll}\text { Table } 2.9 & \text { 7-Day PCT Leaching Results. } & \text { T-11 }\end{array}$

Table 2.10 TCLP Results for the High Iron C-106/AY-102 Glasses and the Associated T-12 UTS and Delisting Limits.

Table 3.1 Summary of Results from DM100 Tests with High Iron, C-106/AY-102 T-13

Waste and Optimized Glass Composition.

Table 3.2 Steady-State Production Rates Achieved on the DM100 Melter with High T-14 Iron, C-106/AY-102 Waste with New (HLW-NG-Fe2) and Baseline (HLW04-09) Glass Compositions at $1150^{\circ} \mathrm{C}$.

Table 3.3 Summary of Measured DM100 Parameters.

Table 4.1 Characteristics of Melter Feed Samples with High Iron, C-106/AY-102 Waste and Optimized Glass Composition.

Table 4.2 XRF Analyzed Compositions of Vitrified Melter Feed Samples (wt \%).

Table 4.3 Comparison of XRF and DCP Analyzed Compositions of Vitrified Melter Feed Samples (wt $\%$ ).

Table 4.4 Listing of Glass Discharged, Masses, and Analysis Performed. $\quad$ T-19

Table 4.5 XRF Analyzed Composition for Glass Discharged During DM100 Melter $\quad$ T-21 Tests $(w t \%)$.

Table 4.6 XRF Analyzed Composition for Dip Samples Taken Before and After $\quad$ T-25

Table 4.7 Results from PCT (ASTM C1285, 7-days at $90^{\circ} \mathrm{C}$, Stainless Steel Vessel; $\quad$ T-26

$\begin{array}{lll}\text { Table } 4.8 & \text { TCLP Results for Discharged Glass Samples (mg/L). } & \text { T-27 }\end{array}$

$\begin{array}{lll}\text { Table } 4.9 & \text { Results of SEM Analysis of Discharged Glasses. } & \text { T-28 }\end{array}$

$\begin{array}{lll}\text { Table 5.1 Results from DM100 Off-Gas Emission Samples. } & \text { T-29 }\end{array}$

Table 5.2 Concentrations (ppmv) of Selected Species in DM100 Exhaust Measured T-30 by FTIR Spectroscopy. 


\section{List of Figures}

Figure 1.1 Schematic diagram of DuraMelter 100 vitrification system.

Figure 1.2.a

Figure 1.2.b

Figure 1.2.c

Figure 1.3

Figure 1.4

Figure 2.1

Figure 2.1

Figure 2.1

Figure 2.1

Figure 2.1

Figure 2.1

Figure 2.2

Figure 2.3

Figure 3.1.a

Figure 3.1.b

Figure 3.2.a

Figure 3.2.b

Figure 3.3.a

Figure 3.3.b

Figure 3.4.a

Figure 3.4.b

Figure 3.5.a

Figure 3.5.b

Figure 3.6.a

Figure 3.6.b

Figure 4.1.a

Figure 4.1.b

Figure 4.1.c

Figure 4.1.d

Figure 4.1.e

Figure 4.1.f

Plan view showing locations of lid ports. conversion test. Gradient Furnace (VGF). c) HLW-NG-Fe2; d) HLW-NG-Fe3. e) HLW-NG-Fe4; f) HLW-NG-Fe5. g) HLW-NG-Fe6; h) HLW-NG-Fe7.

i) HLW-NG-Fe9; j) HLW-NG-Fe10.

k) HLW-NG-Fe 11 . test with optimized bubbling. test with 9 lpm bubbling.

bubbling. bubbling. bubbling. bubbling. with optimized bubbling. with 9 lpm bubbling. optimized bubbling. 9 lpm bubbling.
Schematic diagram showing cross-section through the DM100-BL-melter.

Schematic diagram showing cross-section through the DM100-BL melter.

Schematic diagram showing cross-section through the DM100-BL melter.

Schematic drawing of vertical gradient furnace (VGF) for feed

Temperature gradient (inside the loaded ceramic crucible) of the Vertical

Top and cross section views of high iron feed samples after VGF experiments:

a) HLW-NG-Fe0 (non-radioactive version of HLW04-09); b) HLW-NG-Fe1.

Top and cross section views of high iron feed samples after VGF experiments:

Top and cross section views of high iron feed samples after VGF experiments:

Top and cross section views of high iron feed samples after VGF experiments:

Top and cross section views of high iron feed samples after VGF experiments:

Top and cross section views of high iron feed samples after VGF experiments:

Crystallinity of high iron HLW glasses HLW-NG-Fe1, -Fe2 and -Fe11.

Evaluation of melt rate ranking by VGF as compared to the glass production

rate determined by DM100 melter testing using the same melter feed.

Glass production rates (hourly moving averages and cumulative) for DM100

Glass production rates (hourly moving averages and cumulative) for DM100

Glass temperatures (hourly averages) during DM100 test with optimized

Glass temperatures (hourly averages) during DM100 Test with 9 lpm

Plenum temperatures (hourly averages) during DM100 test with optimized

Plenum temperatures (hourly averages) during DM100 test with 9 lpm

Electrode temperatures and power (hourly averages) during DM100 test

Electrode temperatures and power (hourly averages) during DM100 test

Melt pool resistance and total electrode power during DM100 test with

Melt pool resistance and total electrode power during DM100 test with

Melt pool bubbling during DM100 test with optimized bubbling.

Melt pool bubbling during DM100 test with $9 \mathrm{lpm}$ bubbling.

DM100 product and target glass compositions determined by XRF.

DM100 product and target glass compositions determined by XRF.

DM100 product and target glass compositions determined by XRF.

DM100 product and target glass compositions determined by XRF.

DM100 product and target glass compositions determined by XRF.

DM100 product and target glass compositions determined by XRF. $\underline{\text { Page \# }}$

F-1

F-2

F-3

F-4

F-5

F-6

F-7

F-8

F-9

F-10

F-11

F-12

F-13

F-14

F-15

F-16

F-17

F-18

F-19

F-20

F-21

F-22

F-23

F-24

F-25

F-26

F-27

F-28

F-29

F-30

F-31

F-32 
Figure 4.2

Figure 4.3

Figure 4.4.a

Figure 4.4.b

Figure 5.1

Figure 5.2
DM100 product and target glass compositions determined by DCP-AES.

SEM micrograph of Cr-Ni-Mn iron spinels in glass from test with optimized bubbling.

fixed bubbling.

SEM micrograph of smaller Ni-Mn iron spinels in glass from test with fixed bubbling.

FTIR monitored NO emissions during tests with fixed bubbling.

FTIR monitored water content of exhaust during tests with fixed bubbling.
F-33

F-34

F-35

F-36

F-37

F-38 


\section{List of Abbreviations}

$\begin{array}{ll}\text { ASME } & \text { American Society of Mechanical Engineers } \\ \text { ANL-LRM } & \text { Argonne National Laboratory - Low Activity Waste Reference Material } \\ \text { CCC } & \text { Canister Center Line Cooling } \\ \text { DCP-AES } & \text { Direct Current Plasma Atomic Emission Spectroscopy } \\ \text { DF } & \text { Decontamination Factor } \\ \text { DM } & \text { DuraMelter } \\ \text { DOE } & \text { Department of Energy } \\ \text { DWPF } & \text { Defense Waste Processing Facility } \\ \text { EA } & \text { Environmental Assessment } \\ \text { EDS } & \text { Energy Dispersive X-Ray Spectroscopy } \\ \text { FTIR } & \text { Fourier Transform Infrared Spectroscopy } \\ \text { IC } & \text { Ion Chromatography } \\ \text { HEPA } & \text { High-Efficiency Particulate Air Filter } \\ \text { HLW } & \text { High Level Waste } \\ \text { LAW } & \text { Low Activity Waste } \\ \text { NIST } & \text { National Institute of Standards and Technology } \\ \text { ORP } & \text { Office of River Protection } \\ \text { PCT } & \text { Product Consistency Test } \\ \text { NQA } & \text { Nuclear Quality Assurance } \\ \text { QAPP } & \text { Quality Assurance Project Plan } \\ \text { SEM } & \text { Scanning Electron Microscopy } \\ \text { SOP } & \text { Standard Operating Procedure } \\ \text { SRS } & \text { Savannah River Site } \\ \text { TCLP } & \text { Toxicity Characteristic Leaching Procedure } \\ \text { VGF } & \text { Vertical Gradient Furnace } \\ \text { VSL } & \text { Vitreous State Laboratory } \\ \text { WTP } & \text { Hanford Tank Waste Treatment and Immobilization Plant } \\ \text { WVDP } & \text { West Valley Demonstration Project } \\ \text { XRF } & \text { X-Ray Fluorescence Spectroscopy } \\ \end{array}$




\section{SECTION 1.0 INTRODUCTION}

Projections of the number of High level waste (HLW) canisters to be produced in the Hanford Tank Waste Treatment and Immobilization Plant (WTP) [1] are based upon the inventory of the tank wastes, the anticipated performance of the sludge treatment processes, and current understanding of the capability of the borosilicate glass waste form. The WTP HLW melter design, unlike earlier Department of Energy (DOE) melter designs, incorporates a glass bubbler system. The bubblers create active glass pool convection and thereby improve heat transfer and glass melting rate. The WTP HLW melters each have a glass surface area of $3.75 \mathrm{~m}^{2}$ and depth of $\sim 1.1 \mathrm{~m}$. The two melters in the HLW facility together are designed to produce up to 7.5 MT of glass per day at $100 \%$ availability. Further increases in HLW waste processing rates can potentially be achieved by optimization of the feed and glass formulations for faster melting, increasing the melter operating temperature above $1150^{\circ} \mathrm{C}$, and by increasing the waste loading in the glass product. Increasing the waste loading also has the added benefit of decreasing the number of canisters for storage. This report describes work performed to develop and test new glass and feed formulations in order to increase glass melting rates in high waste loading glass formulations for HLW with high concentrations of iron.

The current estimates and glass formulation efforts have been conservative in terms of achievable waste loadings. These baseline formulations have been specified to ensure that the glasses are homogenous, contain essentially no crystalline phases, are processable in joule-heated, ceramic-lined melters and meet WTP Contract terms. The WTP's overall mission will require the immobilization of tank waste compositions that are dominated by mixtures that include aluminum, chromium, bismuth, iron, phosphorous, zirconium, and sulfur compounds as waste-limiting components. Glass compositions for these waste mixtures have been developed based upon previous experience and current glass property models. In order to improve waste loadings, DOE has initiated a testing program to develop and characterize HLW glasses for wastes that are limited by $\mathrm{Al}, \mathrm{Al}$ plus $\mathrm{Na}, \mathrm{Bi}$, and $\mathrm{Cr}[2,3]$. Results of this work at the Vitreous State Laboratory (VSL) of the Catholic University of America (CUA) have demonstrated the feasibility of increases in waste loading from about $25 \mathrm{wt} \%$ to $33-50 \mathrm{wt} \%$ (based on oxide loading) in the glass, depending on the waste stream. It is expected that these higher waste loading glasses will reduce the HLW canister production requirement by about $25 \%$ or more [3]. Furthermore, it has been shown that a key technological risk area relates to the strong dependence of glass production rate on waste composition [3]. The extent of this variation across the full spectrum of HLW waste types needs to be quantified in order to accurately project waste treatment rates.

DOE HLW treatment programs have featured joule heated ceramic melter (JHCM) technology for the vitrification of high level tank waste. The melter technology used at the West Valley Demonstration Project (WVDP) in New York and at the Defense Waste Processing Facility (DWPF) at the Savannah River Site (SRS) process(ed) HLW in ceramic melters at an operating temperature of $1150^{\circ} \mathrm{C}$. Historically, HLW melters are operated at temperatures of 
$1150^{\circ} \mathrm{C}$ to allow for sufficient temperature control for normal as well as upset conditions in an operating melter, while still protecting the electrodes from potential damage due to unanticipated high temperature swings. Since the HLW melters deployed in the United States at West Valley and originally at DWPF did not actively mix the glass pool, temperature variations within the glass pool were relatively large $\left(\sim \pm 75^{\circ} \mathrm{C}\right)$ with respect to the nominal operating temperature since natural convection within the glass pool is limited in the viscous molten glass. In advancing the technology, EnergySolutions/VSL have demonstrated on very large scale melters (EnergySolutions M-Area facility, WTP HLW Pilot Melter, and the WTP LAW Pilot Melter) that active mixing of the glass pool using our patented bubbler technology not only increases glass production rates but also significantly reduces the temperature gradient within the glass pool, which allows the melter to be controlled in a tighter operating band. Recently, bubblers have been installed in the DWPF melter also, leading to significantly increased processing rates and a reduced temperature gradient in the melt pool.

As a result of the reduced temperature gradient that occurs with bubblers, the melter operating temperature can be modestly increased to about $1175^{\circ} \mathrm{C}$ with the current materials of construction, (and up to about $1225^{\circ} \mathrm{C}$ with changes of electrode and bubbler materials) while maintaining the operating integrity of the melter at the higher temperature. Tests conducted with various HLW waste streams on the DuraMelter (DM)100 and DM1200 melters have demonstrated increases in glass production rates from 0 to 225 percent while increasing the processing temperature from $1150^{\circ} \mathrm{C}$ to $1175^{\circ} \mathrm{C}[3,4]$. Further increases in operating temperature to higher temperatures $\left(1200^{\circ} \mathrm{C}\right)$ have the potential to further increase processing rate as well as increase waste loading, both of which translate into significant cost savings.

Under a separate contract with BNI to support the WTP, VSL has developed and tested glass formulations for WTP HLW waste compositions to provide data to meet the WTP contract requirements and to support system design activities [5-10]. That work was based upon small-scale batch melts ("crucible melts") using waste simulants. Selected formulations were also tested in small-scale, continuously fed, joule-heated melters (DM100 and DM1200) [11-14]. That testing was directed towards waste streams from the then-planned early feed tanks for the WTP (i.e., AZ-101, AZ-102, C-106/AY-102, and C-104/AY-101). These wastes are high in iron (AZ-101, AZ-102 and C-106/AY-102) or thorium (C-104/AY-101) and are significantly different than those used in previous enhancement tests (i.e., wastes limited by $\mathrm{Al}, \mathrm{Al} / \mathrm{Na}, \mathrm{Bi}$, and $\mathrm{Cr}$ ) performed for the Office of River Protection (ORP). Baseline glass formulations to treat these high-Fe wastes were developed under the BNI contract. During that time, the throughput requirement for the HLW melter was initially $400 \mathrm{~kg} / \mathrm{m}^{2} /$ day, which was subsequently increased to $800 \mathrm{~kg} / \mathrm{m}^{2} /$ day. As a result, the baseline high-Fe HLW glass formulations for WTP perform only slightly better than the $800 \mathrm{~kg} / \mathrm{m}^{2} /$ day processing rate requirement. Furthermore, the baseline waste loadings for the Fe-limited HLW compositions are only slightly higher than the BNI contract minimum. Since that time, in work performed for ORP on other HLW compositions, VSL has developed small-scale test methods to assess processing rates of melter feeds and included them as an integral part of glass formulation development. This methodology was used successfully to develop glass formulations for high-Al Hanford HLW that showed processing rates in excess of $2000 \mathrm{~kg} / \mathrm{m}^{2} /$ day while achieving high waste loadings. The same methodology can be applied to the development of improved glass formulations to treat high-Fe 
Hanford HLW in order to provide ORP with a significantly more robust operating envelope with reduced risk of throughput shortfalls.

This report describes work performed to develop and test new glass and feed formulations in order to increase glass melting rates in high waste loading glass formulations for HLW with high concentrations of iron. Testing was designed to identify glass and melter feed formulations that optimize waste loading and waste processing rate while meeting all processing and product quality requirements. The work included preparation and characterization of crucible melts to assess melt rate using a vertical gradient furnace system and to develop new formulations with enhanced melt rate. Testing evaluated the effects of waste loading on glass properties and the maximum waste loading that can be achieved. The results from crucible-scale testing supported subsequent DuraMelter 100 (DM100) tests designed to examine the effects of enhanced glass and feed formulations on waste processing rate and product quality. The DM100 was selected as the platform for these tests due to its extensive previous use in processing rate determination for various HLW streams and glass compositions [3, 11-22]. This work builds on previous work performed at VSL for the DOE to increase waste loadings in HLW glass formulations and processing rates [3, 20-23]. The testing was performed according to the Test Plan that was developed for this work [24].

\subsection{Test Objectives}

The primary objective of the work described herein was to develop and identify HLW glass compositions and glass forming additive blends to maximize waste processing rates for a high-iron HLW stream while maintaining high waste loadings and acceptable glass properties. This was accomplished through a combination of crucible-scale tests, vertical gradient furnace tests, and confirmation tests on the DM100 melter system.

\subsection{Quality Assurance}

This work was conducted under a quality assurance program that is based on Nuclear Quality Assurance (NQA)-1 2004 and NQA-2a (1990) Part 2.7 that is in place at the VSL. The program is compliant with applicable criteria of 10 CFR 830.120; Office of Civilian Waste Management DOE/RW-0333P, Quality Assurance Requirements and Description (QARD) Revision 20; the American Society of Mechanical Engineers (ASME) NQA-1, 2004; and DOE Order 414.1 C, Quality Assurance. This program is supplemented by a Quality Assurance Project Plan (QAPP) for RPP-WTP work [25] that is conducted at VSL. Test and procedure requirements by which the testing activities are planned and controlled are also defined in this plan. The program is supported by VSL standard operating procedures that were used for this work [26]. 


\subsection{DM100 Melter System}

\subsubsection{DM100 Feed System}

A schematic diagram of the DM100 vitrification system is shown in Figure 1.1. The melter feed is introduced in batches into a feed container that is mounted on a load cell for weight monitoring. The feed is stirred with a variable speed mixer and constantly recirculated except for periodic, momentary interruptions during which the weight is recorded. A peristaltic pump is used in order to provide a uniform delivery of feed to the melt surface. Feed is directed from the recirculation loop that extends to the top of the melter and then diverted to the peristaltic pump, which regulates the flow of feed through a Teflon-lined feed line and water-cooled feed tube into the melter.

\subsubsection{Melter System}

Cross-sectional diagrams of the DM100-BL melter are shown in Figures 1.2.a-c. The DM100-BL unit is a ceramic refractory-lined melter fitted with five electrodes: two pairs of opposing Inconel 690 plate electrodes and a bottom electrode. Power can be supplied in either three-phase or single-phase configurations. All of the tests in the present work were performed with the upper and lower electrodes on each side connected together and powered by a single-phase supply; the bottom electrode was not powered. Melt pool agitation is achieved by either a removable lance entering from the top of the melter or a permanent bubbler installed through the bottom electrode. In these tests, the lance bubbler was used. The glass product is removed from the melter by means of an airlift discharge system. The melter has a melt surface area of $0.108 \mathrm{~m}^{2}$ and a variable glass inventory of between $110 \mathrm{~kg}$, when only the bottom pair of electrodes is used, and about $170 \mathrm{~kg}$ when both pairs of electrodes are used, which was the case in the present tests.

\subsubsection{Off-Gas System}

For operational simplicity, the DM100-BL is equipped with a dry off-gas treatment system involving gas filtration operations only. Exhaust gases leave the melter plenum through a film cooler device that minimizes the formation of solid deposits. The film-cooler air has constant flow rate and its temperature is thermostatically controlled. Consequently, under steady-state operating conditions, the exhaust gases passing through the transition line (between the melter and the first filtration device) can be sampled at constant temperature and airflow rate. The geometry of the transition line conforms to the requirements of the 40-CFR-60 air sampling techniques. Immediately downstream of the transition line are cyclonic filters followed by conventional pre-filters and high efficiency particulate air (HEPA) filters. The temperature of the cyclonic filters is maintained above $150^{\circ} \mathrm{C}$ while the temperatures in the HEPAs are kept sufficiently high to prevent moisture condensation. The entire train of gas filtration operations is duplicated and each train is used alternately. An induced draft fan completes the system. 


\subsection{Experimental Procedures and Methods}

\subsubsection{Feed Conversion by Vertical Gradient Furnace (VGF) Testing}

Figure 1.3 shows a schematic diagram of the VGF setup. The temperature gradient inside the VGF is maintained by two separate sets of heating elements, both of which are arranged in cylindrical form and aligned along their axes. The inner heater is set at $1150^{\circ} \mathrm{C}$, which is the nominal temperature of the glass pool, and the ambient heater is set at $600^{\circ} \mathrm{C}$, which is similar to the melter plenum temperature. A ceramic crucible (4 inches tall) is used to contain the reacting melter feed. The temperature gradient in the furnace is shown in Figure 1.4. For a typical feed conversion test, 10 grams of glass of identical chemical composition to the test feed (expressed on an oxide basis) is preheated in the ceramic crucible positioned in the inner heater before the dried melter feed (to yield 20 grams of glass) is introduced. Feed reactions under the controlled temperature gradient are allowed to continue for the designated test duration (typically, from 5 to 60 minutes) and then stopped by rapid cooling in room temperature air. The top surface of the reacted feed material is then inspected and photographed. The crucibles with their feed contents are then cross-sectioned to reveal the conversion progress of feed blends. The saw cuts of the crucibles are performed dry (without lubricant) to avoid loss of any soluble material.

To characterize the reacted feed material, visual inspection and digital imaging of the top (by photography) and cross section (using an optical scanner) of the reacted sample are performed. The results are assessed by comparison to results obtained previously from a wide range of other feeds that have known processing rates from continuous melter testing.

\subsubsection{Feed Samples from Melter Tests}

Feed samples were taken directly from as received drums and the melter feed recirculation line during each test. Feed samples were poured into a platinum/gold crucible and placed into a programmed furnace for drying and fusion to form a glass. The glass produced from this fusion is ground to less than $200 \mathrm{mesh}$ and sealed in 20-ml vials for subsequent analysis by X-ray fluorescence spectroscopy (XRF), or by acid digestion followed by direct-current plasma atomic emission spectroscopy (DCP-AES) on the resulting solution. The feed samples are also characterized for their density, $\mathrm{pH}$, water content, and glass yield.

\subsubsection{Glass Product}

The glass product is discharged from the melter into 5-gallon steel pails periodically using an air-lift system. The discharged product glass is sampled at the end of each test by removing sufficient glass from the top of the cans for compositional analysis and secondary phase determination. In addition, the Product Consistency Test (PCT, 7 days at $90^{\circ} \mathrm{C}$ ) and Toxicity Characteristic Leaching Procedure (TCLP) were performed on samples of the glass product from the DM100 melter tests. Prior to those tests, the PCT and TCLP were also performed on the crucible melt compositions that were selected for the melter tests to ensure 
their compliance with the present WTP contract requirements. All of these procedures are routinely conducted at VSL and, therefore, standard operating procedures (SOPs) are in place.

Sample preparation for chemical analysis typically involves size reduction and sieving. All samples are subjected to $\mathrm{x}$-ray fluorescence spectroscopy (XRF) to determine the concentration of all elements except boron and lithium. A series of National Institute of Standards and Technology (NIST) reference materials are used for confirmation of the XRF data. Boron and lithium are determined by total acid dissolution of ground glass samples in $\mathrm{HF} / \mathrm{HNO}_{3}$ and subjecting the resulting solutions to DCP-AES analysis.

\subsubsection{Viscosity}

The melt viscosity, $\eta$, is measured using a Brookfield viscometer. Measurements are performed in the temperature range of $950-1250^{\circ} \mathrm{C}$ and the data are interpolated to standard temperatures using the Vogel-Fulcher equation: $\ln \eta=[\mathrm{A} /(\mathrm{T}-\mathrm{To})]+\mathrm{B}$, where $\mathrm{A}, \mathrm{B}$, and To are fitting parameters. The equipment is calibrated at room temperature using standard oils of known viscosity and then checked at $950-1250^{\circ} \mathrm{C}$ using a NIST standard reference glass (SRM 711). Both precision and accuracy of the viscosity measurements are estimated to be within \pm 15 relative $\%$.

\subsubsection{Electrical Conductivity}

The electrical conductivity, $\sigma$, of each glass is determined by measuring the resistance of the glass melts as a function of frequency using a calibrated platinum/rhodium electrode probe attached to a Hewlett-Packard model 4194A impedance analyzer. Measurements are performed over similar temperature ranges to those employed for the melt viscosity measurements. The results are analyzed to obtain the DC electrical conductivity. The electrical conductivity data are then interpolated to standard temperatures using the Vogel-Fulcher equation: $\ln \sigma=[\mathrm{A} /(\mathrm{T}-\mathrm{To})]$ $+\mathrm{B}$, where A, B and To are fitting parameters. Estimated uncertainties in the electrical conductivity measurements are \pm 20 relative $\%$.

\subsubsection{Product Consistency Test (PCT)}

The product consistency test (PCT, ASTM C 1285) is used to evaluate the relative chemical durability of glasses by measuring the concentrations of the chemical species released from 100-200 mesh crushed glass $(75-149 \mu \mathrm{m})$ to the test solution (de-ionized water in this case). PCT tests on the HLW glasses are performed at $90^{\circ} \mathrm{C}$, in accordance with the current WTP contract requirement. The ratio of the glass surface area to the solution volume for this test is about $2000 \mathrm{~m}^{-1}$ (typically, $4 \mathrm{~g}$ of 100-200 mesh glass is immersed in $40 \mathrm{ml}$ of deionized water). All tests are conducted in triplicate, in 304L stainless steel vessels, and in parallel with a standard glass included in each test set. The internal standard is the Argonne National Laboratory Low Activity Waste Reference Material (ANL-LRM) glass [27] and/or the DWPF-Environmental Assessmetn (EA) glass, both of which have undergone round-robin testing. The leachates are 
sampled at predetermined times, the first of which is seven days. One milliliter of sampled leachate is mixed with $20 \mathrm{ml}$ of $1 \mathrm{M} \mathrm{HNO}_{3}$ and the resulting solution is analyzed by DCP-AES; another $3 \mathrm{ml}$ of sampled leachate is used for $\mathrm{pH}$ measurement.

\subsubsection{Toxicity Characteristic Leaching Procedure (TCLP)}

The TCLP is performed at VSL using SW-846 Method 1311, which employs leaching of crushed glass $\left(<3 / 8^{\prime \prime}\right)$ in a sodium acetate buffer solution for 18 hours at $22^{\circ} \mathrm{C}$ with constant end-over-end agitation. A mass of about 100 grams of glass is leached in 2 liters of TCLP extract, according to the extraction method for non-volatiles. The surface area to volume ratio for this test is about $20 \mathrm{~m}^{-1}$, which is about two orders of magnitude lower than that in the PCT. The leachates are analyzed by DCP-AES according to VSL standard operating procedures.

\subsubsection{Secondary Phases}

Secondary phases in the glass samples are determined by optical microscopy and scanning electron microscopy coupled with energy dispersive x-ray spectroscopy (SEM-EDS). Secondary phases due to crystallization and phase separation can be identified using these methods. Quantitative determination of the amount of crystals in glass samples are made by SEM in conjunction with image analysis. 


\section{SECTION 2.0 \\ DEVELOPMENT OF HIGH-IRON GLASS FOR C-106/AY-102 HLW}

The WTP baseline glass formulation for C-106/AY-102 that was developed by VSL for BNI several years ago is HLW04-09 [7]. The objective of the present work was to develop new glass formulations for the same waste stream but with increased processing rate and higher waste loadings. Crucible scale tests were used to collect data on a set of new glass formulations and the results were used to down-select a formulation for subsequent melter testing.

Analytical data for actual C-106/AY-102 waste samples were previously provided by the WTP Project for developing HLW glass formulations to support vitrification testing of actual C-106/AY-012 waste [7]. This waste also provided the compositional basis for previous tests on the DM100 [12, 15] and DM1200 [15] melter systems; therefore, extensive baseline melt rate data are available for comparison.

This section summarizes the composition of the C-106/AY-102 simulant, the baseline glass composition previously processed, and the results of new glass formulation development work from which an enhanced high-iron HLW formulation was selected for subsequent melter tests.

\subsection{C-106/AY-102 Waste Simulant}

As part of the BNI WTP research and testing program, samples of Hanford C-106/AY-102 actual waste solids were shipped to Savannah River National Laboratory (SRNL) where they were combined and the composite sample analyzed. Washing and caustic leaching were the HLW pretreatments performed before analysis. Table 2.1 lists the analyzed composition of C-106/AY-102 in terms of non-volatile oxides, as provided by the WTP Project [28]. Table 2.1 also lists the cesium eluate from low activity waste (LAW) pretreatment of AW-101 waste [29], which was blended with the C-106/AY-102 solids to give the HLW simulant for earlier tests $[12,15]$. The blending of LAW pretreatment products is retained in the current HLW simulant so that test data to be obtained can be compared directly with the baseline data. The blending ratio was determined from the WTP dynamic process flowsheet model (G2), with the mass ratio of $\mathrm{AW}-101$ waste oxides to $\mathrm{C}-106 / \mathrm{AY}-102$ oxides equal to about $5.9 \times 10^{-4}$. The blended composition is given in Table 2.1. As can be seen, the AW-101 cesium ion-exchange eluate is essentially composed of a solution of sodium (nitrate) and boron, together with minor amounts of other alkalis and select metal ions, including barium, cerium, copper, nickel, and tin. The blended waste composition is very similar to that of the C-106/AY-102 waste, primarily because of the low blending ratio. It should also be noted that the impact of blending on the iron concentration is negligible.

The blended waste in Table 2.1 contains 32 non-volatile components and was modified to give the HLW simulant for the previous and currents tests. The modifications are made to keep 
the number of components at a manageable level and they include: i) omitting the minor components (i.e., components that make up $<0.05 \mathrm{wt} \%$ in glass, which corresponds to about $0.12 \mathrm{wt} \%$ in waste, on an oxide basis); ii) omitting silver, which was not included in earlier C-106/AY-102 melter tests; and iii) substituting sodium for potassium, lanthanum for gadolinium, and zirconium for uranium (to eliminate the use of radioactive materials). Renormalization after these modifications results in the HLW waste simulant, the composition of which is shown in Table 2.1. It can be seen that iron is by far the most abundant component in the simulant ( $38.12 \mathrm{wt} \% \mathrm{Fe}_{2} \mathrm{O}_{3}$ ), followed by aluminum and manganese (sodium and silicon are present in higher concentrations but both are glass forming additives).

To complete the formulation of the HLW waste simulant, the volatile components need to be defined. For this purpose, the concentrations of carbonate, nitrate, nitrite, and total organic carbon (TOC) from previous C-106/AY-102 melter tests were adopted $[12,15]$. The complete HLW waste simulant is given in Table 2.2.

\subsection{C-106/AY-102 Baseline Glass HLW04-09 and Formulation Constraints}

The baseline glass HLW04-09 developed previously [7] has a nominal waste loading of $37.10 \mathrm{wt} \%$, incorporating $14.01 \mathrm{wt} \%$ of $\mathrm{Fe}_{2} \mathrm{O}_{3}$. This can be compared to the earlier HLW glasses formulated for high-iron wastes for the WTP Project, which are generally designed to demonstrate the capability to comply with the Contract Minimum Component Limits [30] and are limited to about $12.50 \mathrm{wt} \%$ of $\mathrm{Fe}_{2} \mathrm{O}_{3}$ [6]. Waste loadings in high-iron HLW glass formulations are found to be limited typically by the formation of spinel phases. Glass formulation efforts, however, were successful in increasing the waste loadings $\left(>14 \mathrm{wt} \% \mathrm{Fe}_{2} \mathrm{O}_{3}\right)$ by suppressing spinel formation through the addition of various additives [7]. The new formulations developed in this work were required to accommodate at least $14 \mathrm{wt} \% \mathrm{Fe}_{2} \mathrm{O}_{3}$ and comply with all the processing constraints and product quality requirements, while also exhibiting faster melt rates. The reference processing constraints include an operating temperature of $1150^{\circ} \mathrm{C}$ and $<1 \mathrm{vol} \%$ of crystalline phase at the reference temperature of $950^{\circ} \mathrm{C}$. Crucible melts of the HLW glass formulations were prepared and characterized with respect to properties that affect processability and product quality (crystallization, melt viscosity, melt electrical conductivity, PCT, and TCLP). Since spinel crystallization and melt rate are the two most constraining properties, all prepared glasses were characterized with respect to crystallinity (after heat treatment) and melt rate (by VGF). Glasses that did not meet these conditions were not characterized further with respect to the other properties.

\subsection{Development of High-Iron HLW Glass for C-106/AY-102}

As noted above, spinel crystallization was the waste loading limiting constraint in previous glass formulation development work for C-106/AY-102 [7]. As shown in Table 2.2, at $37.1 \mathrm{wt} \%$ waste loading, the baseline formulation HLW04-09 contains, in addition to $14 \mathrm{wt} \%$ $\mathrm{Fe}_{2} \mathrm{O}_{3}$, considerable amounts of $\mathrm{Cr}_{2} \mathrm{O}_{3}(0.22 \%), \mathrm{NiO}(0.41 \%), \mathrm{ZnO}(0.73 \%)$ and $\mathrm{MnO}(2.82 \%)$. As is well-known, these components tend to increase the tendency for spinel formation (see for examples, the review in [31]). 
The new high-iron HLW glass formulations were designed to achieve high waste loadings while accelerating the waste processing rate since the melt rate of the baseline glass, HLW04-09, was only slightly above the required glass production rate of $800 \mathrm{~kg} / \mathrm{m}^{2} /$ day. Therefore the new glass formulation work was bounded by both waste loading $(>37.1 \mathrm{wt} \%)$ and melter processing rate $\left(>800 \mathrm{~kg} / \mathrm{m}^{2} /\right.$ day) constraints. The development work thus relied heavily on the test results from isothermal heat treatments (for crystallinity, which was the waste loading limiting constraint) and the VGF (for melt rate screening). These data were used to down-select prospective candidate formulations which were then subjected to characterization with respect to other properties.

A total of eleven new glasses were formulated and tested in this work. In parallel, melter feeds were also formulated and tested for ten new formulations and the non-radioactive version of the baseline HLW04-09 glass [7] for screening of their relative melt rates in the VGF. Therefore, a total of 22 formulations (glass and melter feeds) were prepared and characterized. The blending recipes of waste and glass forming chemicals for the non-radioactive version of HLW04-09 and the 11 new high-iron formulations are listed in Table 2.3. The target and XRF analyzed compositions of the glasses and fused slurry feed samples are listed in Tables 2.4 and 2.5 , respectively. The general formulation approach used to improve melt rate was similar to that developed previously and demonstrated with great success for other waste types, including WTP and DWPF high aluminum wastes $[21,22,32,33]$. The glass formulations and test results are described below.

\subsubsection{Formulation at $37.1 \mathrm{wt} \%$ Waste Loading}

HLW-NG-Fe1 was formulated at the same waste loading (37.1 wt $\%$ ) as the baseline glass HLW04-09 with the intent of improving the melt rate. As listed in Table 2.3, other than omitting $\mathrm{ZnO}$ as an additive, $3 \mathrm{wt} \%$ additional $\mathrm{B}_{2} \mathrm{O}_{3}$ was used in place of $\mathrm{SiO}_{2}$ and $\mathrm{ZnO}$ ( $2.3 \mathrm{wt} \%$ and $0.7 \mathrm{wt} \%$, respectively) in this glass. Isothermal heat treatment indicated that the $\mathrm{T}_{1 \%}$ of HLW-NG-Fe1 is below $950^{\circ} \mathrm{C}$ (Table 2.6). In order to establish a baseline for melt rate comparison, the slurry sample, HLW-NG-Fe0 which is a non-radioactive version of HLW04-09 was prepared for the vertical gradient furnace experiment (Tables 2.3 and 2.5). As documented previously [22], on the basis of visual inspection of the top and cross sectional views of the VGF test samples, the melt rate of a test formulation can be ranked on a relative scale by the degree of feed conversion (Table 2.7). As shown in Figure 2.1a, the slurry sample HLW-NG-Fe0 was slow to react: a dome structure, which separated the partially reacted feed materials from the heat source and consequently reducing the melt rate, developed and remained stable after 30 minutes. In contrast, the slurry sample of the new formulation, HLW-NG-Fe1, at the same waste loading, melted considerably faster (Figure $2.1 \mathrm{~b}$ ), as intended.

\subsubsection{Formulation at $42 \mathrm{wt} \%$ Waste Loading}

HLW-NG-Fe2 was formulated at a higher waste loading of $42 \mathrm{wt} \%$ (Tables 2.3 and 2.4). Besides 4.9 wt \% more $\mathrm{HLW}, \mathrm{B}_{2} \mathrm{O}_{3}$ and $\mathrm{Na}_{2} \mathrm{O}$ were also added at the expense of $\mathrm{Li}_{2} \mathrm{O}$ and $\mathrm{SiO}_{2}$ in 
comparison to $\mathrm{HLW}-\mathrm{NG}-\mathrm{Fe} 1$. With $16.01 \mathrm{wt} \% \mathrm{Fe}_{2} \mathrm{O}_{3}$ in the glass formulation, more spinel formed after 70 hours heat treatment at all four test temperatures (Table 2.6). HLW-NG-Fe2 showed somewhat slower melt rate than HLW-NG-Fe1 (Figure 2.1c).

\subsubsection{Formulation at $44 \mathrm{wt} \%$ Waste Loading}

At 44 wt $\%$ waste loading, HLW-NG-Fe11 contains 16.8 wt $\% \mathrm{Fe}_{2} \mathrm{O}_{3}$ plus increased levels of other waste components. Consequently, $\mathrm{SiO}_{2}$ in the glass was decreased to $38.3 \mathrm{wt} \%$ at similar sodium and slightly lower lithium concentrations as compared to the baseline formulation HLW-NG-Fe0 (Table 2.4). More $\mathrm{B}_{2} \mathrm{O}_{3}$ was used in HLW-NG-Fe11 than in HLW-NG-Fe2 to control crystallization and enhance melt rate (Table 2.3). The top view and cross section of 30 and 60 minute VGF samples showed that HLW-NG-Fe11 reacted considerably faster than HLW-NG-Fe2 in spite of the $2 \mathrm{wt} \%$ higher waste loading (Figure 2.1k). Overall, the feed conversion progressed in a similar way as in HLW-NG-Fel (37.1 wt\% loading). On the other hand, the crystallization of spinel increased from 0.65 vol. \% (at $42 \mathrm{wt} \%$ loading for HLW-NG-Fe1) to 1.29 vol. \% (at $44 \mathrm{wt} \%$ loading for HLW-NG-Fe11). Figure 2.2 compares the crystallization characteristics of the new formulations at various heat treatment temperatures.

\subsubsection{Formulations at 47 wt \% Waste Loading}

Eight new formulations for C-106/AY-102 HLW were tested at a waste loading of $47 \mathrm{wt} \%$. As listed in Tables 2.3 and 2.4, four new formulations (HLW-NG-Fe3, HLW-NG-Fe4, HLW-NG-Fe5 and HLW-NG-Fe6), which were higher in boron and lower in lithium than the baseline formulation HLW-NG-Fe0, developed dome-like structures after 30 and 60 minute VGF experiments (Figures 2.1d-2.1g). Moreover, 2.5 - 4.5 vol. \% of spinel was present in these glass samples after heat treatment at $950^{\circ} \mathrm{C}$ (Table 2-6). Considerably higher concentrations of sodium and boron in HLW-NG-Fe5, and -Fe6 had no significant impact on the feed conversion process. Following a different route, four other high iron formulations (HLW-NG-Fe7, -Fe8, -Fe9, and Fe10) were developed with considerably lower sodium addition (Table 2.3). Nevertheless, similar dome-like structures remained after 30 minute VGF tests for formulations higher in boron (HLW-NG-NG7) or higher in boron and potassium (HLW-NG-Fe9) (Figures 2.1h, 2,1i), along with considerable amounts of spinel crystals on heat treatment at $950^{\circ} \mathrm{C}$ (Table 2.6). VGF testing was not conducted on formulation HLW-NG-Fe8 because of excessive crystallization after isothermal heat treatment (Table 2.6).

With no added $\mathrm{Na}_{2} \mathrm{O}$ and much higher concentrations of boron, calcium, and lithium (Table 2.3), the melt rate of formulation HLW-NG-Fe10 is comparable to that of HLW-NG-Fe1, even though it has $10 \mathrm{wt} \%$ greater waste loading (Figure $2.1 \mathrm{j}$ ). However, nearly $3 \mathrm{vol} \%$ of spinel crystals was present in HLW-NG-Fe10 after 70 hours heat treatment at $950^{\circ} \mathrm{C}$ (Table 2.6). 


\subsubsection{Selection and Characterization of Candidate Formulation}

\subsubsection{Selection of Candidate Formulation}

As outlined in the Test Plan [24], the primary objective of this work was to improve the melter processing rate and the waste loading of glass formulation for C-106/AY-102 HLW while meeting all processing and product quality requirements. Out of eleven new formulations, two glasses, HLW-NG-Fe1 and HLW-NG-Fe2, meet the screening criterion of $\mathrm{T}_{1 \%}<950^{\circ} \mathrm{C}$ and improved processing rate (Table 2.6). At the baseline waste loading of $37.1 \mathrm{wt} \%$, HLW-NG-Fe1 had less crystallization $\left(0.33\right.$ vol. $\%$ of spinel at $\left.950^{\circ} \mathrm{C}\right)$ and melted fast as judged by VGF test results. At a higher waste loading (42 wt \% vs. $37.1 \mathrm{wt} \%$ ), HLW-NG-Fe2 displayed acceptably low crystallization $\left(0.65 \mathrm{vol} \%\right.$ at $\left.950^{\circ} \mathrm{C}\right)$ and moderately fast melt rate (although somewhat slower than HLW-NG-Fe1).

In an effort to evaluate the processing rate of a candidate formulation, the ranking values of 30 minute VGF experiments were compared with available DM100 operations data. On the basis of VGF experiments of a wide variety of melter feed materials of known processing rates, a correlation has been developed to roughly estimate the melter processing rate from the VGF test results [22]. Using the ranking description from the previous work (Table 2.7), HLW-NG-Fe2 can be ranked around 3 on a scale from 1 (the fastest) to 6 (the slowest), which corresponds to a glass production rate of around $900-1000 \mathrm{~kg} / \mathrm{m}^{2} /$ day (Figure 2.3). For comparison, HLW-NG-Fe0, the non-radioactive version of the baseline glass HLW04-09, is ranked between 5 and 6 , which corresponds to a glass production rate around or below $800 \mathrm{~kg} / \mathrm{m}^{2} / \mathrm{day}$. Considering the increasing extent of spinel crystallization at waste loadings above $42 \mathrm{wt} \%$ (Figure 2.2) and the significantly improved processing rate in comparison to the baseline formulation, high-iron formulation $\mathrm{HLW}-\mathrm{NG}-\mathrm{Fe} 2$ at $42 \mathrm{wt} \%$ waste loading was selected as the melter test candidate for further characterization. Nevertheless, it should be noted that these initial results indicate that an acceptable formulation at $>42 \mathrm{wt} \%$ waste loading would appear to be possible with further development and testing. It is also worth noting that higher waste loading formulations could have been selected if the $\mathrm{T}_{1 \%}$ constraint were to be relaxed from the present WTP baseline value.

\subsubsection{Characterization of HLW-NG-Fe2 Glass}

The key processing and performance parameters for HLW-NG-Fe2 are listed in Table 2.6 and Table 2.8 (for viscosity and electrical conductivity), Table 2.9 (for 7-day PCT), and Table 2.10 (for TCLP). Glass HLW-NG-Fe2 has improved processing rate, acceptable crystallinity, and the melt viscosity and electrical conductivity (around 30 poise and $0.33 \mathrm{~S} / \mathrm{cm}$, respectively, at $1150^{\circ} \mathrm{C}$, Table 2.8 ) are within the limits for melt processing at the WTP. The 7-day PCT leach rates for HLW-NG-Fe2 are low and comparable to those of the baseline glass HLW04-09 (Table 2.9), and an order of magnitude below the leach rates of the DWPF-EA US HLW reference glass. The TCLP leachate concentrations (Table 2.10) are very low and all are acceptable. Glass HLW-NG-Fe2 after heat treatment simulating canister centerline cooling (CCC) showed approximately 4.93 vol. \% spinels by SEM/EDS (Table 2.6). 


\section{SECTION 3.0 DM100 MELTER OPERATIONS}

Two melter tests were conducted on the DM100-BL vitrification system between 12/7/11 and 1/5/12 with high iron C-106/AY-102 waste simulant and the selected optimized glass composition; one test employed optimized bubbling while the other test employed a constant bubbling rate of $91 \mathrm{pm}$. These tests produced over $750 \mathrm{~kg}$ of glass from over $2000 \mathrm{~kg}$ of feed. Prior to the two melter tests, the glass inventory was reduced from about $170 \mathrm{~kg}$ to about $110 \mathrm{~kg}$ in order to decrease the feeding time required to change over the composition of the melt pool; the melter was then fed sufficient target feed to re-fill the melter and discharge over $100 \mathrm{~kg}$ of glass.

In both tests, the glass temperature was held constant at $1150^{\circ} \mathrm{C}$ while feeding to determine the effect of the test variables on production rate and processing properties as well as to facilitate comparison with previously conducted tests. Both tests were also conducted with the same high iron C-106/AY-102 waste simulant, glass composition, feed solids content targeted at $500 \mathrm{~g}$ glass per liter of feed, and a nominal duration of fifty hours. The two tests were distinguished by optimizing bubbling during the first test in order to maximize production rate and fixing the bubbling rate at $9 \mathrm{lpm}$ per minute in the second test in order to provide a direct comparison to the results from previous tests. Summaries of the tests are provided in Table 3.1. Attempts were made to replicate the melter configuration and operating conditions used for previous tests with HLW simulants [3, 11-23]. These conditions include a near-complete cold cap, which is between $80-95 \%$ melt surface coverage for the DM100 since a $100 \%$ cold cap tends to lead to "bridging" in smaller melters. The bubbling rate was either fixed at $9 \mathrm{lpm}$ or optimized and the feed rate was adjusted to maintain a complete cold cap. This use of fixed bubbling is in contrast to some previous tests where the production rate was fixed between 1000 and $1050 \mathrm{~kg} / \mathrm{m}^{2} /$ day and the bubbling rate was adjusted to maintain the complete cold cap $[13-15,18]$.

The feed and glass were processed without significant difficulties throughout the majority of the tests. Cold cap conditions were similar to the range of conditions observed in previous tests with HLW feeds [3, 10-23]. The feed formed some shelves and bridges, although not to the rate limiting extent observed while processing some high aluminum formulations $[3,21]$ or some high iron formulations [19]. On average, manual methods were used every four hours to dislodge these deposits without any interruptions in feeding. On several occasions during the first test, "stalactites" were also removed from the bottom of the feed tube to prevent feed tube clogging. Between 24 and 33 hours run time during the first test, clogs in the feed lines resulted in feeding interruptions totaling about a hundred minutes to clear feed lines, replace tubes, and repair pinch valves. Shorter, routine interruptions were required during testing to transfer feed to the feed tank, adjust the feed line in the peristaltic pump as a result of wear from the pump rollers, and perform other maintenance activities. Another complication during the first test occurred due to inadvertent over feeding of the melter shortly after the initiation of feeding; time was required to consume excess feed on the melt surface before establishing a steady state feed rate over the 
latter portion of the test. No foamy glass was observed in the glass discharge and no foam was observed on the melt pool surface or cold cap.

Figures 3.1.a and 3.1.b illustrate the glass production rates as moving hourly and cumulative averages during testing. The cumulative average rate for both tests was about $1600 \mathrm{~kg} / \mathrm{m}^{2} /$ day. The instantaneous rate throughout the test at fixed bubbling varied around $1650 \mathrm{~kg} / \mathrm{m}^{2} /$ day while the instantaneous rate for the test with optimized bubbling varied between 1000 and $2300 \mathrm{~kg} / \mathrm{m}^{2} /$ day. The lower production rates during the test with optimized bubbling correspond to a recovery period following over feeding of the melter and during the clearing of clogs in the feed line. The steady state rate of $1900 \mathrm{~kg} / \mathrm{m}^{2} /$ day was estimated from the last 20 hours of the test with optimized bubbling after all clogs were removed from feed lines. Steady state production rates for current and previous tests $[12,15]$ conducted at $9 \mathrm{lpm}$ fixed bubbling or optimized bubbling with the same waste composition are tabulated in Table 3.2. Taken together, the past and present test results show significant increases in production rate with the new glass formulation as compared to the previous baseline formulation:

- Glass production rates increased by $41 \%$ (1900 vs. $1350 \mathrm{~kg} / \mathrm{m}^{2} /$ day) with the new glass formulation when using optimized bubbling.

- Glass production rates increased by $38 \%$ (1650 vs. $1200 \mathrm{~kg} / \mathrm{m}^{2} /$ day) with the new glass formulation when using fixed bubbling.

The increase in waste processing rate is even greater as a result of the combined effects of the higher waste loading (42 vs. $37.1 \mathrm{wt} \%$ oxide) and the higher melt rate for the new formulation developed for the current tests as compared to the previous baseline formulation. Compared with previous tests conducted with the same waste but using the previous baseline glass formulation:

- Waste processing rates increased by $59 \%$ (798 vs. $501 \mathrm{~kg} / \mathrm{m}^{2} /$ day) with the new glass formulation when using optimized bubbling.

- Waste processing rates increased by $56 \%$ (693 vs. $445 \mathrm{~kg} / \mathrm{m}^{2} /$ day) with the new glass formulation when using fixed bubbling.

The results of various operational measurements that were made during these tests are given in Table 3.3. Glass temperatures are shown in Figures 3.2.a and 3.2.b, plenum temperatures in Figures 3.3.a and 3.3.b, electrode temperatures in Figures 3.4.a and 3.4.b, glass resistance in Figures 3.5.a and 3.5.b, melt pool bubbling in Figures 3.6.a and 3.6.b; electrode power is included in the figures with electrode temperatures and glass resistance. Bulk glass temperatures (measured at 5 and 10 inches from the bottom of the melt pool) were largely within $10^{\circ} \mathrm{C}$ of the target glass temperatures of $1150^{\circ} \mathrm{C}$ throughout the vast majority of the tests. Glass temperatures closer to the top of the melt pool (measured at 16 and 27 inches from the bottom) are not reliable indicators of bulk glass temperatures as a result of their sensitivity to variations in the level of glass in the melter and gradients near the melt surface. The temperature of the air lift increases from the discharge chamber temperature of about $1000^{\circ} \mathrm{C}$ to about $1120^{\circ} \mathrm{C}$ during glass 
discharge events. The two electrode pairs were typically 50 to $100^{\circ} \mathrm{C}$ colder than the glass pool, depending on the measured points in the glass pool and electrodes, the amount of bubbling used, and the time within the test. The bottom electrode, which was not powered, was 300 to $350^{\circ} \mathrm{C}$ colder than the powered side electrodes.

Plenum temperatures ranged from $450^{\circ} \mathrm{C}$ to $550^{\circ} \mathrm{C}$ and from $400^{\circ} \mathrm{C}$ to $500^{\circ} \mathrm{C}$ during steady processing for tests with optimized and fixed bubbling, respectively. Higher plenum temperatures were measured at the beginning of both tests during the development of the cold cap. Lower plenum temperatures were observed between five and ten hours run time during the first test as a result of over feeding the melter. Plenum temperatures measured in the thermowell were on average about $30-50^{\circ} \mathrm{C}$ lower than those measured by the exposed thermocouple during the test with optimized bubbling, while the opposite trend was observed in the test with fixed bubbling. This is likely due to variations in cold cap coverage with differing exposure of the exposed thermocouple and thermowell to openings in the cold cap between the two tests.

Bubbling rates ranged mostly between 10 and $15 \mathrm{lpm}$ while being optimized during the first test. The target bubbling rate of $9 \mathrm{lpm}$ was maintained throughout the second test. Power supplied to the electrodes averaged $26 \mathrm{~kW}$ during both tests; during steady state processing the power was about 30 and $25 \mathrm{~kW}$ for tests conducted with optimized and fixed bubbling, respectively. More power was required during these tests than for previous tests with the same waste composition $[12,15]$ as a result of the higher glass production rates. The average power usage normalized to glass production was relatively low, $3.5-3.6 \mathrm{kWhr} / \mathrm{kg}$, due to much of the supplied energy being used to maintain the glass pool at the target melt temperature (i.e., the essentially constant idling power); thus higher production rates result in relatively lower normalized power usage. During the steady state portion of the first test and the majority of the second test, the melt pool resistance was relatively constant between 0.07 and 0.085 ohms as a result of the lack of compositional change and constant glass pool temperature of $1150^{\circ} \mathrm{C}$.

The gas temperature at the film cooler averaged about $284^{\circ} \mathrm{C}$ and depended on the plenum temperature, the amount of added film cooler air, and the temperature of the added film cooler air. Drops of less than fifteen degrees in gas temperature were observed across the (insulated) transition line; the high temperature is maintained in order to prevent condensation in the downstream filtration units. 


\section{SECTION 4.0 \\ FEED SAMPLE AND GLASS PRODUCT ANALYSIS}

\subsection{Analysis of Feed Samples \\ 4.1.1 General Properties}

Feed samples from each test were analyzed to confirm physical properties and chemical composition. Samples were taken during melter testing from either an inline sampling port or directly from the feed drum. Sample names and measured properties are given in Table 4.1. Density, $\mathrm{pH}$, water content, glass conversion ratio, and oxide composition by XRF and DCP were measured on all samples. The measured glass conversion ratios for all feed samples were within six percent of the target on a weight per weight basis, validating the use of the target conversion ratio for calculating glass production rates. The water content, density, glass yield, and $\mathrm{pH}$ varied within a narrow range for the feed samples.

\subsubsection{Chemical Composition}

The methods used for analysis of feed sample chemical compositions are described in Section 1.4. The boron and lithium oxide concentrations from the DCP-AES analysis were used for normalizing the XRF data since their concentrations were not determined by XRF. These results, compared to the target composition in Table 4.2 , generally show agreement with the target composition and corroborate the consistency of the feed for the major elements. The average analysis shows that oxides with target concentrations greater than one weight percent deviated by less than $10 \%$ from target for all but manganese and zirconium. The absolute deviation for zirconium is small and is not observed in the product glass. Conversely, all feed and product glasses are about twenty three percent ( 0.75 weight percent absolute) deficient in manganese oxide. Variations in oxide concentrations of boron, iron, silicon, and sodium are observed among the three samples; however, the magnitude of the variability would not be expected to significantly affect the processing properties of the feed. Low concentrations of cadmium, potassium, and titanium were found, even though they are not included in the target composition. Also, common elements such as magnesium, zinc, sulfur, and barium, targeted at low concentrations, were typically above these targets. These positive deviations are often observed in melter feeds due to their ubiquity in the raw materials used to make up the simulants and in the glass forming additives. Corroborative analysis using DCP on solutions of acid-dissolved glass was performed on select glasses produced from each test; the results are compared to the XRF analysis in Table 4.3. Values for most oxides compare favorably with the $\mathrm{XRF}$ analysis and target composition except for sodium, which often exhibits a low bias using this procedure [34]. The manganese concentrations determined using the DCP method were higher than the XRF method although not sufficiently high to account for all of the deficiency. 


\subsection{Analysis of Glass Samples}

Over $750 \mathrm{~kg}$ of glass was produced in these tests. The glass was discharged from the DM100 periodically into 5-gallon carbon steel pails using an air lift system. The discharged product glass was sampled by removing sufficient glass from the top of each pail for total inorganic analysis. Product glass masses, discharge date, and analysis performed are given in Table 4.4. Glass samples were also taken by inserting a threaded metal rod directly into the glass pool. These "dip" samples serve to document the composition of the glass pool before and after each test.

\subsubsection{Compositional Analysis of Discharge and Dip Sample Glasses}

All discharge glass samples were crushed and analyzed directly by XRF. Select glasses were subjected to DCP analysis to determine boron and lithium concentrations since these are not determined by XRF; boron and lithium concentrations were interpolated from the analyzed samples for the remainder of the glasses. The XRF analyzed compositions of discharged and dip glass samples are provided in Tables 4.5 and 4.6, respectively. The majority of the XRF analysis results compare favorably to their corresponding target values and feed sample analyses (see Section 4.1.2). Oxides with a target concentration greater than one weight percent showed less than $10 \%$ deviation from the target values for the test average composition except for manganese and aluminum. The manganese deficit of about three quarters of an absolute percent was also observed in feed samples. The aluminum surplus was not observed in feed samples and resulted from incomplete turnover of the glass pool from the previous test, which contained glass with greater than $24 \mathrm{wt} \%$ alumina [22]. Similar to the feed sample analyses, common elements such as magnesium, zinc, sulfur, and barium targeted at low concentrations were above their respective targets. The amount of sulfur in the product glass is higher than analyzed in the feed samples indicating greater loss of sulfur during crucible melting of feed than vitrification while processing through the melter with a cold cap on the melt surface. Small amounts of bismuth, cadmium, cesium, neodymium, potassium, titanium, and vanadium were measured in the glasses despite not being included in the current target composition as a result of being present in the melt pool prior to these tests or being present in the feed as a contaminant.

Compositional trends for selected constituents shown in Figures 4.1.a-4.2 illustrate the closeness to targets over the majority of the tests. Exceptions include manganese, which remains significantly below target concentration after an initial increase in concentration, and potassium, which is present in the feed as a contaminant. At the onset of testing, iron, boron, and manganese increase in concentration at the expense of aluminum, silicon, iron, zinc, and zirconium. Also bismuth, cadmium, vanadium, cesium, and neodymium present in the melt pool at the beginning of testing but not present in the target glass composition decrease in concentration to below measurable levels or to the trace contamination levels measured in feed samples. Concentrations of sodium, lithium, magnesium, nickel, and chromium change little over the course of testing due to similarities between the initial glass composition and the target composition and the consistency of the feed used throughout these tests. 


\subsubsection{Chemical Durability of Discharge Glasses}

Glass discharge samples from the end of each DM100 test were evaluated for chemical durability using the PCT and TCLP methods. The PCT results are compared to those for the benchmark DWPF-EA glass in Table 4.7 and the TCLP results are compared to the WTP delisting limits $[35,36]$ and Universal Treatment Standard (UTS) limits in Table 4.8. The chemical durability determined for the melter glasses by both of these methods is excellent. All measured PCT concentrations and normalized leach rates on discharge glass samples are at least seventy times lower than the corresponding values for the DWPF-EA glass. All regulated TCLP leachate concentrations are less than $1 \mathrm{mg} / 1$ and more than a factor of hundred less than WTP delisting limits. All measured concentrations are also well below the UTS limits. The chemical durability of these glasses is similar to those of glasses produced from wastes limited by bismuth, chromium, aluminum, and aluminum plus sodium [3] and iron [19, 23]. These results confirm that glasses can be formulated with higher iron contents and with faster processing rates without compromising the quality of the vitrified product.

\subsubsection{SEM Analysis of Glass Samples}

The glass from the last discharge of each of the two tests was subjected to SEM analysis to determine the extent of crystal formation. The results are summarized in Table 4.9 and illustrated in Figures 4.3 and 4.4. The observed crystalline phases were spinels containing iron, chromium, manganese, and nickel, ranging from 0.1 to 1.1 volume percent in the samples. Both samples contain about 0.1 volume percent euhedral equant spinel crystals of 5-10 micron size. The sample from the end of the test with fixed bubbling also contained spinels of $0.2-1$ micron size, clustered in string patterns of sub-euhedral equant grains composing about 0.95 volume percent of the sample. Given the glass composition, spinel chemical composition, and thermal history of the two glass samples is virtually the same, these minor differences are likely just a result of sample to sample variations with the product glasses. 


\section{SECTION 5.0 \\ MONITORED OFF-GAS EMISSIONS}

\subsection{Particulate Sampling}

The melter exhaust was sampled for metals/particles according to 40-CFR-60 Methods 3, 5, and 29 at steady-state operating conditions during each test segment. The concentrations of off-gas species that are present as particulates and gaseous species that are collected in impinger solutions were derived from laboratory data on solutions extracted from air samples (filters and various solutions) together with measurements of the volume of air sampled. Particulate collection required isokinetic sampling, which entails removing gas from the exhaust at the same velocity that the air is flowing in the duct (40-CFR-60, Methods 1-5). Typically, a sample size of $30 \mathrm{dscf}$ was taken at a rate of between 0.5 and $0.75 \mathrm{dscfm}$. Total particulate loading was determined by combining gravimetric analysis of the standard particle filter and chemical analysis of probe rinse solutions. An additional impinger containing $2 \mathrm{~N} \mathrm{NaOH}$ was added to the sampling train to ensure complete scrubbing of all acid gases and, particularly, iodine. The collected materials were analyzed using direct current plasma atomic emission spectroscopy for the majority of the constituents and ion chromatography (IC) for anions. Melter emission fluxes are compared to feed fluxes and emission samples taken while processing the same glass composition in Table 5.1. Notice the distinction that is made between constituents sampled as particles and as "gas". The "gaseous" constituents are operationally defined as those species that are scrubbed in the impinger solutions after the air stream has passed through a $0.3 \mu \mathrm{m}$ heated filter. Both samples were slightly above, $113 \%$, the $90-110 \%$ limits for isokinetic sampling.

Particulate emissions constituted 0.66 and 0.71 percent of feed solids. This level of carryover is well within the range measured while processing various feeds containing high iron $\mathrm{HLW}$ simulants processed on the same melter at a temperature of $1150^{\circ} \mathrm{C}$ : AZ-102 $(0.57-1.47$ percent) [18]; C-106/AY-102 SIPP (0.61 to 0.81 percent) [12]; waste compositions limited by the formation of iron and chromium mineral phases $(0.47-1.81$ percent $)$ [19]; and the former C-106/AY-102 baseline (0.3 - 0.74 percent) [16]. However, the emissions from the current tests exceed measured carryover for previous tests with chromium, bismuth, aluminum, and aluminum plus sodium limited HLW wastes $(0.04-0.57)$ [3, 21, 22] and HLW AZ-101 (0.46 percent) [20] processed under the same melter conditions. Carryover is a function of the amount of volatile constituents in the feed and the conditions in the melter, particularly the completeness and uniformity of the cold cap. The data from the current tests confirm the observations of the cold cap during testing, which was partly irregular but mostly complete, similar to that observed for many previously tested HLW feed streams. Higher levels of carryover were observed in tests with high volatile contents (rhenium, cesium, and halogens) [18] and very poor cold cap development [19]. In tests with the high aluminum waste, which contains very little volatiles, solids carryover was considerably lower at $0.04-0.48[21,22]$. As expected, emissions were slightly higher during the test with higher bubbling than for the test with bubbling fixed at $91 \mathrm{pm}$. 
As expected, the feed element emitted at the lowest melter decontamination factor (DF) was clearly sulfur. Other elements exhibiting some volatile behavior were boron and chromium. The relative carryover of barium, tin, and zinc are difficult to evaluate due to the low target concentrations and trace contamination in the feed. The percent carryover of calcium, magnesium, sulfur, and zinc shown in Table 5.1 are biased high due to higher actual concentrations in the feed than the target concentrations. Although the actual feed concentrations are difficult to determine due to low feed concentrations and variable trace contamination the feed concentrations of magnesium and zinc are estimated at approximately twice the target value and therefore the carryover percent would be approximately half that reported on the basis of the nominal target composition. Likewise, based on feed analysis results, sulfur concentrations in the feed were $23 \%$ percent above target; therefore the percent sulfur carryover would be correspondingly lower (total sulfur emitted for the two samples of 63 and 68 percent of measured feed). Analytical results showed more sulfur in the product glass than in the feed samples indicating that the actual amount of sulfur in the feed was considerably higher; therefore the amount of carryover would be less than that reported based on the target or feed concentrations. Boron and sulfur were the only elements detected in the impinger solutions collected downstream of the heated particle filter in the sampling train, which constitutes the "gas" fraction of the melter emissions.

\subsection{Gases Monitored by FTIR}

Melter emissions were monitored in each test for a variety of gaseous components, most notably $\mathrm{CO}$ and nitrogen species, by Fourier Transform Infra Red Spectroscopy (FTIR). The off-gas system temperature is maintained well above $100^{\circ} \mathrm{C}$ beyond the sampling port downstream of the DM100 HEPA filter to prevent analyte loss due to condensation prior to monitoring. The data, therefore, represent the relative concentrations of volatile gaseous species in the melter exhaust. The internal heater within the FTIR malfunctioned during the test with optimized bubbling and therefore no reliable data on these gaseous species were collected for this test. A summary of the range and average concentrations of gaseous species monitored during the test with fixed bubbling is provided in Table 5.2. The analytes listed in Table 5.2 are those that were thought likely to be observed during the tests based on previous work; no other species were detected in the off-gas stream by FTIR. The concentrations of two monitored species, nitrogen monoxide and water, are plotted in Figures 5.1 and 5.2. Generally, emissions from the DM100 were relatively low as a result of the low concentrations of nitrogen, organic carbon, ammonia, and halogens in the feed. The most abundant nitrogen species monitored was NO, which is in keeping with previous melter tests with both HLW and LAW feeds. Little or no nitrogen was detected as other species. The concentrations of water and NO in the melter exhaust were relatively constant in response to relatively constant feed rate. The scatter in the emissions data over the course of the tests is due in part to changes in the cold cap. Also consistent with the Method 5-type results, low sulfur dioxide concentrations were monitored in each test; however, gaseous sulfur emissions can also be present in forms other than sulfur dioxide that are not monitored by the FTIR, such as sulfuric acid. 


\section{SECTION 6.0 SUMMARY AND CONCLUSIONS}

The WTP baseline glass formulation for C-106/AY-102 that was developed by VSL for BNI several years ago is HLW04-09 [7]. That work showed that the waste loading for this high iron waste stream was limited by spinel formation. Furthermore, melter tests showed that the glass production rate was only marginally greater than the WTP requirement. The objective of the present work was to develop new glass formulations for the same waste stream but with increased processing rate and higher waste loadings. Crucible scale tests were used to collect data on a set of new glass formulations and the results were used to down-select a formulation for subsequent melter testing on the DM100 vitrification system.

The baseline glass HLW04-09 developed previously [7] has a nominal waste loading of $37.10 \mathrm{wt} \%$, incorporating $14.01 \mathrm{wt} \%$ of $\mathrm{Fe}_{2} \mathrm{O}_{3}$. The new formulations developed in this work were required to accommodate at least $14 \mathrm{wt} \% \mathrm{Fe}_{2} \mathrm{O}_{3}$ and comply with all the processing constraints and product quality requirements, while also exhibiting faster melt rates. The reference processing constraints include an operating temperature of $1150^{\circ} \mathrm{C}$ and $<1 \mathrm{vol} \%$ of crystalline phase at the reference temperature of $950^{\circ} \mathrm{C}$. Crucible melts of the HLW glass formulations were prepared and characterized with respect to properties that affect processability and product quality (crystallization, melt viscosity, melt electrical conductivity, PCT, and TCLP). Since spinel crystallization and melt rate are the two most constraining properties, all prepared glasses were characterized with respect to crystallinity (after heat treatment) and melt rate (by VGF screening tests). Glasses that did not meet these conditions were not characterized further with respect to the other properties. A total of eleven new glasses were formulated and tested in this work. In parallel, melter feeds were also formulated and tested for ten new formulations and the non-radioactive version of the baseline HLW04-09 glass for screening of their relative melt rates in the VGF. Therefore, a total of 22 formulations (glass and melter feeds) were prepared and characterized. As expected, spinel formation was found to be the waste loading limiting constraint and increased with increasing waste loading. Based on the test results, the new high-iron formulation HLW-NG-Fe2 was selected as the melter test candidate for further characterization. This formulation has a waste loading of $42 \mathrm{wt} \%$ (vs. $37.1 \mathrm{wt} \%$ for the baseline glass) and showed significantly improved melt rate on VGF screening tests as compared to the baseline formulation.

A series of melter tests were conducted on the DM100 using the same C-106/AY-102 HLW simulant but with the newly developed glass formulation, HLW-NG-Fe2. Tests on the DM100 were conducted at $1150^{\circ} \mathrm{C}$ at the nominal bubbling rate of $9 \mathrm{lpm}$ and also with optimized bubbling to achieve maximum production rates; these conditions were selected to allow comparison to results obtained previously with high iron C-106/AY-102 HLW simulants [12, 15]. The feed rate was adjusted to provide the desired complete cold cap. The principal results of these tests can be summarized as follows: 
- Waste loading increased from 37.1 to $42 \mathrm{wt} \%$ while meeting all WTP process and product quality requirements and maintaining acceptable glass and feed processing properties.

- Glass production rates increased by $41 \%$ (1900 vs. $1350 \mathrm{~kg} / \mathrm{m}^{2} /$ day) with the new glass formulation when using optimized bubbling.

- Glass production rates increased by $38 \%$ (1650 vs. $1200 \mathrm{~kg} / \mathrm{m}^{2} /$ day) with the new glass formulation when using fixed bubbling.

The increase in waste processing rate is even greater as a result of the combined effects of the higher waste loading and the higher melt rate of the new formulation developed for the current tests as compared to the previous baseline formulation. Compared with previous tests conducted with the same waste but using the previous baseline glass formulation:

- Waste processing rates increased by $59 \%$ (798 vs. $501 \mathrm{~kg} / \mathrm{m}^{2} / \mathrm{day}$ ) with the new glass formulation when using optimized bubbling.

- Waste processing rates increased by $56 \%$ (693 vs. $445 \mathrm{~kg} / \mathrm{m}^{2} /$ day) with the new glass formulation when using fixed bubbling.

The results from the melter tests confirmed those from the crucible scale glass formulation work, demonstrating an increase in glass production rate of about forty percent despite the higher waste loading. Coupled with higher waste loadings for the optimized formulation, waste processing rates were increased by greater than fifty percent. The results also demonstrate that processing rates can be increased by a factor of about two over the WTP HLW baseline requirement using these new formulations in combination with optimization of melt pool bubbling.

Melter exhaust was sampled during each processing rate test for particulate and gaseous species to determine the effect of changing feed composition and bubbling rate on emissions. Particulate emissions from the melter constituted 0.66 and 0.71 percent of feed solids, consistent with previous tests with this waste stream and many other HLW streams. Melter DFs were determined for most elements in the feed. The most volatile species was sulfur, which is typical. Other elements exhibiting volatile behavior in some of the tests include boron and chromium. Gaseous emissions of nitrogen oxides and byproducts of incomplete combustion, such as carbon monoxide and ammonia, were very low due to the lack of nitrates and organic carbon in the feed.

Glass samples from the crucible and melter tests were subjected to leach testing using the PCT and TCLP methods in order to evaluate product quality. Despite the higher waste loadings and re-formulation for increased melt rate, the glass products significantly out-performed the DWPF-EA benchmark glass on the PCT leaching procedure by at least one or two orders of magnitude and exhibited TCLP leachate concentrations that were well below the WTP delisting limits. 


\subsection{Recommendations for Future Work}

The results of the testing presented herein further demonstrate the viability of the enhancement and optimization strategies that have been developed in previous work for ORP [3, 19-24, 32, 33]. Furthermore, the results have the potential for enormous savings in cost and schedule. As a result, it is recommended that testing and evaluation of these strategies be continued in order to provide a solid basis for their broad implementation in order to maximize the cost and schedule benefits while minimizing technical risk. Further work that is recommended for optimization of processing of WTP high iron HLW feed is outlined below.

- Glass Formulation: Despite the limited nature of the present study, very significant enhancements of waste processing rates (through increases in both waste loading and melt rate) have been demonstrated. The results from the glass formulation work indicate that further improvements may be possible through a second phase of glass formulation optimization using the results of the present work as a basis.

- Scale-Up Testing: As in the previous enhancement work for ORP, testing should be extended to larger-scale melter systems in order to address potential risks associated with scale-up, particularly with respect to processing rates. Testing should be conducted at the DM1200 WTP HLW Pilot Melter scale (1.2 mP2P). Optimization of bubbling rate is a critical variable and therefore testing with bubblers in the prototypical orientation at larger scale is required to confirm these findings.

- Integrated System Testing: Testing on the DM1200 WTP HLW Pilot Melter system provides data from a one-third scale system with a prototypical feed delivery system and off-gas treatment train. Such testing is necessary to evaluate potential interactive effects on system operation arising from implementation of the enhancement strategies and to provide data on the performance of each unit operation, input for flow-sheet models and regulatory requirements, and information of recycle streams.

- Longer-Duration Testing: After validation at larger scale, the duration of testing should be extended in order to address and quantify any chronic issues, such as the slow accumulation of crystals in the melter cavity, any degradation in the ability to discharge glass, and effects on off-gas line plugging.

- Other WTP High Iron HLW Waste Types: The present testing was based on a single high iron HLW composition from the Hanford tanks. Subsequent work should extend these results to address the full range of high iron HLW feeds expected to be processed at the WTP.

- Throughput: A key risk area addressed in the present work relates to the strong dependence of glass production rates on waste composition and the extent to which shortfalls in processing rate can be mitigated through reformulation of the baseline glass compositions. The extent of this variation and potential shortfall across the full spectrum of HLW waste types needs to be quantified in order to accurately project waste treatment rates. 


\section{SECTION 7.0}

REFERENCES

[1] "HLW Glass Development Testing," Contract Number DE- RP27-07RV14884, US Department of Energy, Office of River Protection, Richland, WA, 2007.

[2] "Test and Evaluate High Level Waste (HLW) Vitrification System Improvements," Contract Number DE-AC27-06RV14790, US Department of Energy, Office of River Protection, Richland, WA, April, 2006.

[3] "High Level Waste Vitrification System Improvements," K.S. Matlack, H. Gan, W. Gong, I.L. Pegg, C.C. Chapman, and I. Joseph, Final Report, VSL-07R1010-1, Rev. 0, Vitreous State Laboratory, The Catholic University of America, Washington, DC, 04/16/07.

[4] "Integrated DM1200 Melter Testing of Bubbler Configurations Using HLW AZ-101 Simulants," K.S. Matlack, W. Gong, T. Bardakci, N. D’Angelo, W. Lutze, R. A. Callow, M. Brandys, W.K. Kot, and I.L. Pegg, Final Report, VSL-04R4800-4, Rev. 0, Vitreous State Laboratory, The Catholic University of America, Washington, DC, 10/05/04.

[5] "Glass Formulation and Testing with RPP-WTP HLW Simulants," W.K. Kot, and I.L. Pegg, Final Report, VSL-01R2540-2, Rev. 0, Vitreous State Laboratory, The Catholic University of America, Washington, DC, 2/16/01.

[6] "Glass Formulation to Support Melter Runs with HLW Simulants," W.K. Kot, K. Klatt, and I.L. Pegg, Final Report, VSL-03R3760-2, Rev. 0, Vitreous State Laboratory, The Catholic University of America, Washington, DC, 09/30/03.

[7] "HLW Glass Formulation to Support C-106/AY-102 Actual Waste Testing," W.K. Kot and I.L. Pegg, Final Report, VSL-04R4770-1, Rev. 0, Vitreous State Laboratory, The Catholic University of America, Washington, DC, 08/12/04.

[8] "Development of Phase 1 IHLW Models for PCT Response and One-Percent Crystal Fraction Temperature $\left(\mathrm{T}_{1 \%}\right)$," W.K. Kot, H. Gan, Z. Feng, F. Perez-Cardenas, I.L. Pegg, S.K. Cooley, and G.F. Piepel, Final Report, VSL-05R5780-1, Rev. 0, Vitreous State Laboratory, The Catholic University of America, Washington, DC, 04/12/05.

[9] "Preparation and Testing $\left(\mathrm{T}_{1 \%}\right.$ and PCT) of HLW Matrix Glasses to Support WTP Property-Composition Model Development," W.K. Kot, H. Gan, and I.L. Pegg, Final Report, VSL-05R5780-2, Rev. 0, Vitreous State Laboratory, The Catholic University of America, Washington, DC, 10/12/05. 
[10] "Summary and Recommendations on Viscosity and Conductivity Model Forms to Support HLW Vitrification," H. Gan, Z. Feng, and I.L. Pegg, Letter Report, VSL-04L4780-1, Rev. 0, Vitreous State Laboratory, The Catholic University of America, Washington, DC, 09/08/04.

[11] "Melter Tests with AZ-101 HLW Simulant Using a DuraMelter 100 Vitrification System," K.S. Matlack, W.K. Kot, and I.L. Pegg, Final Report, VSL-01R10N0-1, Rev. 1, Vitreous State Laboratory, The Catholic University of America, Washington, DC, $02 / 25 / 01$.

[12] "DuraMelter 100 HLW Simulant Validation Tests with C-106/AY-102 Feeds," K.S. Matlack, W. Gong and I.L. Pegg, Final Report, VSL-05R5710-1, Rev. 0, Vitreous State Laboratory, The Catholic University of America, Washington, DC, 6/2/05.

[13] "Integrated DM1200 Melter Testing of HLW C-106/AY-102 Composition Using Bubblers," K.S. Matlack, W. Gong, T. Bardakci, N. D’Angelo, W. Kot and I.L. Pegg, Final Report, VSL-03R3800-1, Rev. 0, Vitreous State Laboratory, The Catholic University of America, Washington, DC, 9/15/03.

[14] "Integrated DM1200 Melter Testing of HLW C-104/AY-101 Compositions Using Bubblers," K.S. Matlack, W. Gong, T. Bardakci, N. D'Angelo, W. Kot and I.L. Pegg, Final Report, VSL-03R3800-3, Rev. 0, Vitreous State Laboratory, The Catholic University of America, Washington, DC, 11/24/03.

[15] "Integrated DM1200 Melter Testing Using AZ-102 and C-106/AY-102 HLW Simulants: HLW Simulant Verification," K.S. Matlack, W. Gong, T. Bardakci, N. D'Angelo, M. Brandys, W.K. Kot, and I.L. Pegg, Final Report, VSL-05R5800-1, Rev. 0, Vitreous State Laboratory, The Catholic University of America, Washington, DC, 6/27/05.

[16] "Small Scale Melter Testing of HLW Algorithm Glasses: Matrix 1 Tests," K.S. Matlack, W.K. Kot, W. Gong and I.L. Pegg, Final Report, VSL-07R1220-1, Rev. 0, Vitreous State Laboratory, The Catholic University of America, Washington, DC, 11/12/07.

[17] "Small Scale Melter Testing of HLW Algorithm Glasses: Matrix 2 Tests," K.S. Matlack, W.K. Kot, W. Gong and I.L. Pegg, Final Report, VSL-08R1220-1, Rev. 0, Vitreous State Laboratory, The Catholic University of America, Washington, DC, 6/27/08.

[18] "Technetium/Cesium Volatility in DM100 Tests Using HLW AZ-102 and LAW Sub-Envelope A1 Simulants," K.S. Matlack, W.K. Kot, and I.L. Pegg, Final Report, VSL-04R4710-1, Rev. 0, Vitreous State Laboratory, The Catholic University of America, Washington, DC, 9/28/04.

[19] "Effects of High Spinel and Chromium Oxide Crystal Contents on Simulated HLW Vitrification in DM100 Melter Tests," K.S. Matlack, W.K. Kot, W. Gong, W. Lutze,, I Joseph, and I.L. Pegg, Final Report, VSL-09R1520-1, Rev. 0, Vitreous State Laboratory, The Catholic University of America, Washington, DC, 6/19/09. 
[20] "Next Generation Advanced Joule-Heated Melter Bench Scale Testing," K.S. Matlack, W.K. Kot, I.L. Pegg, and I. Joseph, Final Report, VSL-11R2320-1, Rev. 0, Vitreous State Laboratory, The Catholic University of America, Washington, DC, 10/13/11.

[21] "Melt Rate Enhancement for High Aluminum HLW Glass Formulations," K.S. Matlack, H. Gan, M. Chaudhuri, W.K. Kot, W. Gong, T. Bardakci, and I.L. Pegg, Final Report, VSL-08R1360-1, Rev. 0, Vitreous State Laboratory, The Catholic University of America, Washington, DC, 12/19/08.

[22] "DM100 and DM1200 Melter Testing with High Waste Loading Glass Formulations for Hanford High-Aluminum HLW Streams," K.S. Matlack, H. Gan, M. Chaudhuri, W.K Kot, W. Gong, T. Bardakci, I. Joseph, and I.L. Pegg, Final Report, VSL-10R1690-1, Rev. A, Vitreous State Laboratory, The Catholic University of America, Washington, DC, $5 / 17 / 10$.

[23] "HLW Enhancement Tests on the DuraMelter"M 10 with Hanford AZ-102 Tank Waste Simulants," K.S. Matlack, W.K. Kot, H. Gan, R.K. Mohr, W. Gong, and I.L. Pegg, Final Report, VSL-06R5260-1, Rev. 0, Vitreous State Laboratory, The Catholic University of America, Washington, DC, 02/28/06.

[24] "Melter Throughput Enhancements for High-Iron HLW," W.K. Kot, K.S. Matlack, and I.L. Pegg, Test Plan, VSL-11T2490-1, Rev. 0, Vitreous State Laboratory, The Catholic University of America, Washington, DC, 06/20/11.

[25] "Quality Assurance Project Plan for ORP/ RPP-WTP Support Activities Conducted by VSL," Vitreous State Laboratory, QAPP-ORP, Rev. 2, Vitreous State Laboratory, The Catholic University of America, Washington, DC, 2/2/10.

[26] "Master List of Controlled VSL Manuals and Standard Operating Procedures in Use," QA-MLCP, Rev. 61, Vitreous State Laboratory, The Catholic University of America, Washington, DC, 3/31/11.

[27] "Round Robin Testing of a Reference Glass for Low-Activity Waste Forms," W.L. Ebert and S.F. Wolf, Department of Energy report ANL-99/22, Argonne National Laboratory, Argonne, IL, 1999.

[28] "AY-102/C-106 Actual Waste Sample Glass Formulation Guidance," CCN 067620 , RPP-WTP Memorandum, C. Musick, to I.L. Pegg, March 23, 2004.

[29] "Multiple Ion Exchange Column runs for Cesium and Technetium Removal from AW-101 Waste Sample (U)," N.M. Hassan, K. Adu-Wusu, and C.A. Nash, WSRC-TR2003-00098, Rev. 0 (SRT-RPP-2003-00026, Rev. 0), Westinghouse Savannah River Company, Aiken, SC, July 2003. 
[30] Bechtel National, Inc., Design, Construction, and Commissioning of the Hanford Tank Waste Treatment and Immobilization Plant Contract Number: DE-AC27-01-RV14136, $8 / 31 / 20$.

[31] "Crystallization in High-Level Waste Glasses," P. Hrma, in Environmental Issues and Waste Management Technologies, VII, Ceramic Transactions Vol. 132, pp 243-256 (2006).

[32] "High Aluminum HLW Glasses for Hanford's WTP, I. Joseph, B.W. Bowan, H. Gan, W.K. Kot, K.S. Matlack, I.L. Pegg and A.A. Kruger, Paper 10241, Proc. Waste Management Symposium, Phoenix Arizona (2010).

[33] "Tests of Simultaneous Melt Rate and Waste Loading Enhancement for DWPF HLW Streams," B.W. Bowan, I. Joseph, K.S. Matlack, H. Gan, W.K. Kot, and I.L. Pegg, Paper 10254, Proc. Waste Management Symposium, Phoenix Arizona (2010).

[34] "Review of Properties of Simulated Feeds Used for Melter Testing," K.S. Matlack, W. Gong, and I.L. Pegg, Final Report, VSL-06R6410-1, Rev. 0, Vitreous State Laboratory, The Catholic University of America, Washington, DC, Washington, D.C., 8/16/06.

[35] "New Delisting Limits for Arsenic and Chrome," D. Blumenkranz, e-mail message to J. Westsik, CCN 069211, River Protection Project, Waste Treatment Plant, Richland, WA. 9/15/03.

[36] "Data Quality Objectives Process in Support of LDR/Delisting at the WTP," J. Cook and D. Blumenkranz, 24590-WTP-RPT-ENV-01-012, Rev. 2, River Protection Project, Waste Treatment Plant, Richland, WA, 3/26/03. 
Table 2.1. Compositional Summary (wt\% Oxide Basis) of the C-106/AY-102 Actual Waste, AW-101 Cesium-Eluate, Blended Waste, and the High-Iron HLW Simulant.

\begin{tabular}{|c|c|c|c|c|}
\hline Oxide & $\begin{array}{c}\text { Analyzed } \\
\text { C-106/AY-102 } \\
\text { Solid }\end{array}$ & $\begin{array}{c}\text { Analyzed } \\
\text { AW-101 } \\
\text { Cesium-Eluate }\end{array}$ & $\begin{array}{c}\text { Blended } \\
\text { C-106/AY-102 } \\
\text { Actual Waste }\end{array}$ & $\begin{array}{l}\text { High-Iron } \\
\text { HLW Simulant }\end{array}$ \\
\hline $\mathrm{Ag}_{2} \mathrm{O}$ & $0.50 \%$ & - & $0.50 \%$ & - \\
\hline $\mathrm{Al}_{2} \mathrm{O}_{3}$ & $13.17 \%$ & - & $13.16 \%$ & $13.29 \%$ \\
\hline $\mathrm{B}_{2} \mathrm{O}_{3}$ & $0.70 \%$ & $33.18 \%$ & $0.73 \%$ & $0.74 \%$ \\
\hline $\mathrm{BaO}$ & $0.20 \%$ & $1.68 \%$ & $0.20 \%$ & $0.20 \%$ \\
\hline $\mathrm{CaO}$ & $1.23 \%$ & - & $1.23 \%$ & $1.24 \%$ \\
\hline $\mathrm{CdO}$ & $0.03 \%$ & $0.38 \%$ & $0.03 \%$ & - \\
\hline $\mathrm{Ce}_{2} \mathrm{O}_{3}$ & $0.27 \%$ & $4.91 \%$ & $0.27 \%$ & $0.27 \%$ \\
\hline $\mathrm{Cr}_{2} \mathrm{O}_{3}$ & $0.60 \%$ & $0.69 \%$ & $0.60 \%$ & $0.61 \%$ \\
\hline $\mathrm{Cs}_{2} \mathrm{O}$ & - & $3.36 \%$ & $0.00 \%$ & $0.00 \%$ \\
\hline $\mathrm{CuO}$ & $0.09 \%$ & $2.57 \%$ & $0.09 \%$ & - \\
\hline $\mathrm{Fe}_{2} \mathrm{O}_{3}$ & $37.78 \%$ & $0.41 \%$ & $37.74 \%$ & $38.12 \%$ \\
\hline $\mathrm{Gd}_{2} \mathrm{O}_{3}$ & $0.02 \%$ & - & $0.02 \%$ & - \\
\hline $\mathrm{K}_{2} \mathrm{O}$ & $0.03 \%$ & - & $0.03 \%$ & - \\
\hline $\mathrm{La}_{2} \mathrm{O}_{3}$ & $0.20 \%$ & $0.85 \%$ & $0.20 \%$ & $0.22 \%$ \\
\hline $\mathrm{Li}_{2} \mathrm{O}$ & $0.11 \%$ & $7.34 \%$ & $0.12 \%$ & $0.12 \%$ \\
\hline $\mathrm{MgO}$ & $0.39 \%$ & - & $0.39 \%$ & $0.39 \%$ \\
\hline $\mathrm{MnO}$ & $7.61 \%$ & - & $7.60 \%$ & $7.68 \%$ \\
\hline $\mathrm{MoO}_{3}$ & $0.09 \%$ & - & $0.09 \%$ & - \\
\hline $\mathrm{Na}_{2} \mathrm{O}$ & $14.48 \%$ & $35.73 \%$ & $14.50 \%$ & $14.68 \%$ \\
\hline $\mathrm{NiO}$ & $1.11 \%$ & $1.36 \%$ & $1.11 \%$ & $1.12 \%$ \\
\hline $\mathrm{P}_{2} \mathrm{O}_{5}$ & $1.51 \%$ & - & $1.51 \%$ & $1.53 \%$ \\
\hline $\mathrm{PbO}$ & $1.46 \%$ & - & $1.46 \%$ & $1.47 \%$ \\
\hline $\mathrm{SO}_{3}$ & $0.51 \%$ & - & $0.51 \%$ & $0.52 \%$ \\
\hline $\mathrm{Sb}_{2} \mathrm{O}_{5}$ & $0.11 \%$ & - & $0.11 \%$ & - \\
\hline $\mathrm{SiO}_{2}$ & $14.28 \%$ & - & $14.27 \%$ & $14.41 \%$ \\
\hline $\mathrm{SnO}_{2}$ & $0.16 \%$ & $6.83 \%$ & $0.17 \%$ & $0.17 \%$ \\
\hline $\mathrm{SrO}$ & $0.46 \%$ & $0.71 \%$ & $0.46 \%$ & $0.46 \%$ \\
\hline $\mathrm{TiO}_{2}$ & $0.09 \%$ & - & $0.09 \%$ & - \\
\hline $\mathrm{U}_{3} \mathrm{O}_{8}$ & $1.40 \%$ & - & $1.40 \%$ & - \\
\hline $\mathrm{V}_{2} \mathrm{O}_{5}$ & $0.04 \%$ & - & $0.04 \%$ & - \\
\hline $\mathrm{ZnO}$ & $0.08 \%$ & - & $0.08 \%$ & $0.08 \%$ \\
\hline $\mathrm{ZrO}_{2}$ & $1.25 \%$ & - & $1.25 \%$ & $2.68 \%$ \\
\hline TOTAL & $100.0 \%$ & $100.0 \%$ & $100.0 \%$ & $100.0 \%$ \\
\hline
\end{tabular}

- Empty data field 
Table 2.2. Compositional Summary of the High-Iron HLW Simulant, Reference Glass HLW04-09, and Target Glass for Previous Melter Tests [12, 15].

\begin{tabular}{|c|c|c|c|}
\hline $\begin{array}{l}\text { Oxide } \\
(\text { wt\%) }\end{array}$ & $\begin{array}{c}\text { High-Iron } \\
\text { HLW Simulant }\end{array}$ & HLW04-09 & $\begin{array}{c}\text { Target Glass for } \\
\text { Previous Melter Tests }\end{array}$ \\
\hline $\mathrm{Ag}_{2} \mathrm{O}$ & - $^{(1)}$ & $0.19 \%$ & - \\
\hline $\mathrm{Al}_{2} \mathrm{O}_{3}$ & $13.29 \%$ & $4.88 \%$ & $4.89 \%$ \\
\hline $\mathrm{B}_{2} \mathrm{O}_{3}$ & $0.74 \%$ & $10.27 \%$ & $10.27 \%$ \\
\hline $\mathrm{BaO}$ & $0.20 \%$ & $0.07 \%$ & $0.07 \%$ \\
\hline $\mathrm{CaO}$ & $1.24 \%$ & $0.46 \%$ & $0.46 \%$ \\
\hline $\mathrm{CdO}$ & - & $0.01 \%$ & - \\
\hline $\mathrm{Ce}_{2} \mathrm{O}_{3}$ & $0.27 \%$ & $0.10 \%$ & $0.10 \%$ \\
\hline $\mathrm{Cr}_{2} \mathrm{O}_{3}$ & $0.61 \%$ & $0.22 \%$ & $0.22 \%$ \\
\hline $\mathrm{Cs}_{2} \mathrm{O}$ & $0.00 \%$ & $0.00 \%$ & $0.00 \%$ \\
\hline $\mathrm{CuO}$ & - & $0.03 \%$ & - \\
\hline $\mathrm{Fe}_{2} \mathrm{O}_{3}$ & $38.12 \%$ & $14.01 \%$ & $14.03 \%$ \\
\hline $\mathrm{Gd}_{2} \mathrm{O}_{3}$ & - & $0.01 \%$ & - \\
\hline $\mathrm{K}_{2} \mathrm{O}$ & - & $0.01 \%$ & - \\
\hline $\mathrm{La}_{2} \mathrm{O}_{3}$ & $0.22 \%$ & $0.07 \%$ & $0.08 \%$ \\
\hline $\mathrm{Li}_{2} \mathrm{O}$ & $0.12 \%$ & $2.64 \%$ & $2.64 \%$ \\
\hline $\mathrm{MgO}$ & $0.39 \%$ & $0.14 \%$ & $0.14 \%$ \\
\hline $\mathrm{MnO}$ & $7.68 \%$ & $2.82 \%$ & $2.82 \%$ \\
\hline $\mathrm{MoO}_{3}$ & - & $0.03 \%$ & - \\
\hline $\mathrm{Na}_{2} \mathrm{O}$ & $14.68 \%$ & $12.53 \%$ & $12.55 \%$ \\
\hline $\mathrm{NiO}$ & $1.12 \%$ & $0.41 \%$ & $0.41 \%$ \\
\hline $\mathrm{P}_{2} \mathrm{O}_{5}$ & $1.53 \%$ & $0.56 \%$ & $0.56 \%$ \\
\hline $\mathrm{PbO}$ & $1.47 \%$ & $0.54 \%$ & $0.54 \%$ \\
\hline $\mathrm{SO}_{3}$ & $0.52 \%$ & $0.19 \%$ & $0.19 \%$ \\
\hline $\mathrm{Sb}_{2} \mathrm{O}_{5}$ & - & $0.04 \%$ & - \\
\hline $\mathrm{SiO}_{2}$ & $14.41 \%$ & $47.75 \%$ & $47.75 \%$ \\
\hline $\mathrm{SnO}_{2}$ & $0.17 \%$ & $0.06 \%$ & $0.06 \%$ \\
\hline $\mathrm{SrO}$ & $0.46 \%$ & $0.17 \%$ & $0.17 \%$ \\
\hline $\mathrm{TiO}_{2}$ & - & $0.03 \%$ & - \\
\hline $\mathrm{U}_{3} \mathrm{O}_{8}$ & - & $0.52 \%$ & - \\
\hline $\mathrm{V}_{2} \mathrm{O}_{5}$ & - & $0.01 \%$ & - \\
\hline $\mathrm{ZnO}$ & $0.08 \%$ & $0.73 \%$ & $1.03 \%$ \\
\hline $\mathrm{ZrO}_{2}$ & $2.68 \%$ & $0.46 \%$ & $0.98 \%$ \\
\hline TOTAL & $100.0 \%$ & $100.0 \%$ & $100.0 \%$ \\
\hline Volatiles ( $\mathrm{g} / 100 \mathrm{~g}$ oxide) & - & - & - \\
\hline Carbonate & 4.650 & - & - \\
\hline Nitrite & 0.012 & - & - \\
\hline Nitrate & 0.784 & - & - \\
\hline TOC & 0.026 & - & - \\
\hline
\end{tabular}

-Empty data field 
Table 2.3. Blending Recipes for High Iron HLW Formulations.

\begin{tabular}{|c|c|c|c|c|c|c|c|c|c|c|c|}
\hline \multirow{2}{*}{ Formulation } & \multirow{2}{*}{$\begin{array}{c}\text { Waste (Oxide wt\%) } \\
\text { C-106/AY-102 }\end{array}$} & \multicolumn{9}{|c|}{ Glass Forming Chemicals (wt\%) } & \multirow{2}{*}{ Sum $(w t \%)$} \\
\hline & & $\mathrm{Al}_{2} \mathrm{O}_{3}$ & $\mathrm{~B}_{2} \mathbf{O}_{3}$ & $\mathrm{CaO}$ & $\mathbf{K}_{2} \mathbf{O}$ & $\mathbf{L i}_{2} \mathbf{O}$ & $\mathrm{Na}_{2} \mathrm{O}$ & $\mathrm{SiO}_{2}$ & $\mathrm{~V}_{2} \mathrm{O}_{5}$ & $\mathrm{ZnO}$ & \\
\hline HLW-NG-Fe0* & 37.10 & 0.00 & 10.00 & 0.00 & 0.00 & 2.60 & 7.15 & 42.45 & 0.00 & 0.70 & 100.00 \\
\hline HLW-NG-Fe1 & 37.10 & 0.00 & 13.00 & 0.00 & 0.00 & 2.60 & 7.15 & 40.15 & 0.00 & 0.00 & 100.00 \\
\hline HLW-NG-Fe2 & 42.00 & 0.00 & 13.50 & 0.00 & 0.00 & 1.50 & 8.00 & 35.00 & 0.00 & 0.00 & 100.00 \\
\hline HLW-NG-Fe3 & 47.00 & 0.00 & 13.50 & 0.00 & 0.00 & 2.00 & 6.50 & 31.00 & 0.00 & 0.00 & 100.00 \\
\hline HLW-NG-Fe4 & 47.00 & 0.00 & 13.50 & 0.00 & 0.00 & 0.00 & 7.50 & 31.00 & 1.00 & 0.00 & 100.00 \\
\hline HLW-NG-Fe5 & 47.00 & 0.00 & 15.00 & 0.00 & 0.00 & 0.00 & 9.00 & 29.00 & 0.00 & 0.00 & 100.00 \\
\hline HLW-NG-Fe6 & 47.00 & 3.00 & 15.00 & 0.00 & 0.00 & 0.00 & 9.00 & 26.00 & 0.00 & 0.00 & 100.00 \\
\hline HLW-NG-Fe7 & 47.00 & 0.00 & 16.00 & 0.00 & 0.00 & 2.00 & 5.00 & 30.00 & 0.00 & 0.00 & 100.00 \\
\hline HLW-NG-Fe8 & 47.00 & 0.00 & 18.00 & 0.00 & 0.00 & 3.00 & 3.00 & 29.00 & 0.00 & 0.00 & 100.00 \\
\hline HLW-NG-Fe9 & 47.00 & 0.00 & 16.00 & 0.00 & 4.00 & 2.00 & 1.00 & 30.00 & 0.00 & 0.00 & 100.00 \\
\hline HLW-NG-Fe10 & 47.00 & 0.00 & 18.00 & 8.00 & 0.00 & 5.00 & 0.00 & 22.00 & 0.00 & 0.00 & 100.00 \\
\hline HLW-NG-Fe11 & 44.00 & 0.00 & 15.00 & 0.00 & 0.00 & 3.00 & 6.00 & 32.00 & 0.00 & 0.00 & 100.00 \\
\hline
\end{tabular}

* - HLW04-09 from [7] 
Table 2.4. Target and XRF Analyzed Compositions of High Iron HLW Glasses for C-106/AY-102.

\begin{tabular}{|c|c|c|c|c|c|c|c|c|c|c|c|}
\hline Glass ID & HLW-NG-Fe0 ${ }^{*}$ & \multicolumn{2}{|c|}{ HLW-NG-Fe1 } & \multicolumn{2}{|c|}{ HLW-NG-Fe2 } & \multicolumn{2}{|c|}{ HLW-NG-Fe3 } & \multicolumn{2}{|c|}{ HLW-NG-Fe4 } & \multicolumn{2}{|c|}{ HLW-NG-Fe5 } \\
\hline $\begin{array}{c}\text { Waste Loading } \\
\text { (wt } \%)\end{array}$ & 37 & \multicolumn{2}{|c|}{37} & \multicolumn{2}{|c|}{42} & \multicolumn{2}{|c|}{47} & \multicolumn{2}{|c|}{47} & \multicolumn{2}{|c|}{47} \\
\hline Data Type & Target & Target & $\mathrm{XRF}$ & Target & $\mathrm{XRF}$ & Target & $\mathrm{XRF}$ & Target & $\mathrm{XRF}$ & Target & $\mathrm{XRF}$ \\
\hline $\mathrm{Al}_{2} \mathrm{O}_{3}$ & 4.93 & 4.93 & 4.73 & 5.58 & 5.32 & 6.25 & 5.82 & 6.25 & 5.80 & 6.25 & 5.89 \\
\hline $\mathrm{B}_{2} \mathrm{O}_{3}$ & 10.27 & 13.27 & 13.27 & 13.81 & 13.81 & 13.85 & 13.85 & 13.85 & 13.85 & 15.35 & 15.35 \\
\hline $\mathrm{BaO}$ & 0.07 & 0.07 & 0.09 & 0.08 & 0.10 & 0.09 & 0.12 & 0.09 & 0.12 & 0.09 & 0.12 \\
\hline $\mathrm{CaO}$ & 0.46 & 0.46 & 0.50 & 0.52 & 0.06 & 0.58 & 0.61 & 0.58 & 0.63 & 0.58 & 0.63 \\
\hline $\mathrm{CeO}_{2}$ & 0.10 & 0.10 & 0.10 & 0.11 & 0.13 & 0.13 & 0.14 & 0.13 & 0.15 & 0.13 & 0.14 \\
\hline $\mathrm{Cr}_{2} \mathrm{O}_{3}$ & 0.23 & 0.23 & 0.27 & 0.26 & 0.30 & 0.29 & 0.34 & 0.29 & 0.35 & 0.29 & 0.36 \\
\hline $\mathrm{Fe}_{2} \mathrm{O}_{3}$ & 14.14 & 14.14 & 13.51 & 16.01 & 15.33 & 17.92 & 17.20 & 17.92 & 17.74 & 17.92 & 18.09 \\
\hline $\mathrm{K}_{2} \mathrm{O}$ & 0.00 & 0.00 & 0.00 & 0.00 & 0.00 & 0.00 & 0.00 & 0.00 & 0.00 & 0.00 & 0.00 \\
\hline $\mathrm{La}_{2} \mathrm{O}_{3}$ & 0.08 & 0.08 & 0.00 & 0.09 & 0.00 & 0.10 & 0.00 & 0.10 & 0.00 & 0.10 & 0.00 \\
\hline $\mathrm{Li}_{2} \mathrm{O}$ & 2.64 & 2.64 & 2.64 & 1.55 & 1.55 & 2.06 & 2.06 & 0.06 & 0.06 & 0.06 & 0.06 \\
\hline $\mathrm{MgO}$ & 0.14 & 0.14 & 0.14 & 0.16 & 0.16 & 0.18 & 0.16 & 0.18 & 0.13 & 0.18 & 0.18 \\
\hline $\mathrm{MnO}$ & 2.85 & 2.85 & 2.89 & 3.23 & 3.28 & 3.61 & 3.69 & 3.61 & 3.80 & 3.61 & 3.86 \\
\hline $\mathrm{Na}_{2} \mathrm{O}$ & 12.60 & 12.60 & 13.85 & 14.17 & 15.33 & 13.40 & 14.51 & 14.40 & 14.90 & 15.90 & 16.03 \\
\hline $\mathrm{NiO}$ & 0.42 & 0.42 & 0.38 & 0.47 & 0.43 & 0.53 & 0.49 & 0.53 & 0.49 & 0.53 & 0.51 \\
\hline $\mathrm{P}_{2} \mathrm{O}_{5}$ & 0.57 & 0.57 & 0.71 & 0.64 & 0.82 & 0.72 & 0.88 & 0.72 & 0.96 & 0.72 & 0.86 \\
\hline $\mathrm{PbO}$ & 0.55 & 0.55 & 0.47 & 0.62 & 0.54 & 0.69 & 0.61 & 0.69 & 0.63 & 0.69 & 0.64 \\
\hline $\mathrm{SnO}_{2}$ & 0.06 & 0.06 & 0.07 & 0.07 & 0.07 & 0.08 & 0.09 & 0.08 & 0.08 & 0.08 & 0.09 \\
\hline $\mathrm{SiO}_{2}$ & 47.80 & 45.50 & 45.05 & 41.05 & 40.79 & 37.77 & 37.76 & 37.77 & 37.62 & 35.77 & 35.45 \\
\hline $\mathrm{SrO}$ & 0.17 & 0.17 & 0.16 & 0.19 & 0.17 & 0.22 & 0.20 & 0.22 & 0.21 & 0.22 & 0.21 \\
\hline $\mathrm{ThO}_{2}$ & 0.00 & 0.00 & 0.00 & 0.00 & 0.00 & 0.00 & 0.00 & 0.00 & 0.00 & 0.00 & 0.00 \\
\hline $\mathrm{SO}_{3}$ & 0.19 & 0.19 & 0.17 & 0.22 & 0.15 & 0.24 & 0.17 & 0.24 & 0.13 & 0.24 & 0.13 \\
\hline $\mathrm{V}_{2} \mathrm{O}_{5}$ & 0.00 & 0.00 & 0.00 & 0.00 & 0.00 & 0.00 & 0.00 & 1.00 & 0.97 & 0.00 & 0.00 \\
\hline $\mathrm{ZnO}$ & 0.73 & 0.03 & 0.03 & 0.03 & 0.04 & 0.04 & 0.04 & 0.04 & 0.04 & 0.04 & 0.04 \\
\hline $\mathrm{ZrO}_{2}$ & 0.99 & 0.99 & 0.88 & 1.13 & 0.97 & 1.26 & 1.10 & 1.26 & 1.16 & 1.26 & 1.17 \\
\hline Sum & 100.00 & 100.00 & 99.88 & 100.00 & 99.36 & 100.00 & 99.82 & 100.00 & 99.81 & 100.00 & 99.82 \\
\hline
\end{tabular}

* - Prepared as the baseline slurry feed only for VGF experiments. 
Table 2.4. Target and XRF Analyzed Compositions of High Iron HLW Glasses for C-106/AY-102 (continued).

\begin{tabular}{|c|c|c|c|c|c|c|c|c|c|c|c|c|}
\hline Glass ID & \multicolumn{2}{|c|}{ HLW-NG-Fe6 } & \multicolumn{2}{|c|}{ HLW-NG-Fe7 } & \multicolumn{2}{|c|}{ HLW-NG-Fe8 } & \multicolumn{2}{|c|}{ HLW-NG-Fe9 } & \multicolumn{2}{|c|}{ HLW-NG-Fe10 } & \multicolumn{2}{|c|}{ HLW-NG-Fe11 } \\
\hline $\begin{array}{c}\text { Waste Loading } \\
(\mathrm{wt} \%)\end{array}$ & \multicolumn{2}{|c|}{47} & \multicolumn{2}{|c|}{47} & \multicolumn{2}{|c|}{47} & \multicolumn{2}{|c|}{47} & \multicolumn{2}{|c|}{47} & \multicolumn{2}{|c|}{44} \\
\hline Data type & Target & $\mathrm{XRF}$ & Target & XRF & Target & $\mathrm{XRF}$ & Target & XRF & Target & $\mathrm{XRF}$ & Target & $\mathrm{XRF}$ \\
\hline $\mathrm{Al}_{2} \mathrm{O}_{3}$ & 9.25 & 8.76 & 6.25 & 5.75 & 6.25 & 5.87 & 6.25 & 5.77 & 6.25 & 6.08 & 5.85 & 5.67 \\
\hline $\mathrm{B}_{2} \mathrm{O}_{3}$ & 15.35 & 15.35 & 16.35 & 16.35 & 18.35 & 18.35 & 16.35 & 16.35 & 18.35 & 18.35 & 15.33 & 15.33 \\
\hline $\mathrm{BaO}$ & 0.09 & 0.01 & 0.09 & 0.13 & 0.09 & 0.13 & 0.09 & 0.12 & 0.09 & 0.12 & 0.09 & 0.15 \\
\hline $\mathrm{CaO}$ & 0.58 & 0.63 & 0.58 & 0.64 & 0.58 & 0.63 & 0.58 & 0.64 & 8.58 & 8.59 & 0.55 & 0.60 \\
\hline $\mathrm{CeO}_{2}$ & 0.13 & 0.15 & 0.13 & 0.15 & 0.13 & 0.16 & 0.13 & 0.15 & 0.13 & 0.14 & 0.12 & 0.13 \\
\hline $\mathrm{Cr}_{2} \mathrm{O}_{3}$ & 0.29 & 0.32 & 0.29 & 0.36 & 0.29 & 0.35 & 0.29 & 0.34 & 0.29 & 0.29 & 0.27 & 0.27 \\
\hline $\mathrm{Fe}_{2} \mathrm{O}_{3}$ & 17.92 & 18.05 & 17.92 & 18.03 & 17.92 & 18.06 & 17.92 & 18.00 & 17.92 & 17.17 & 16.77 & 16.74 \\
\hline $\mathrm{K}_{2} \mathrm{O}$ & 0.00 & 0.00 & 0.00 & 0.00 & 0.00 & 0.00 & 4.00 & 3.55 & 0.00 & 0.02 & 0.00 & 0.01 \\
\hline $\mathrm{La}_{2} \mathrm{O}_{3}$ & 0.10 & 0.00 & 0.10 & 0.00 & 0.10 & 0.04 & 0.10 & 0.00 & 0.10 & 0.09 & 0.10 & 0.09 \\
\hline $\mathrm{Li}_{2} \mathrm{O}$ & 0.06 & 0.06 & 2.06 & 2.06 & 3.06 & 3.06 & 2.06 & 2.06 & 5.06 & 5.06 & 3.05 & 3.05 \\
\hline $\mathrm{MgO}$ & 0.18 & 0.15 & 0.18 & 0.14 & 0.18 & 0.20 & 0.18 & 0.14 & 0.18 & 0.19 & 0.17 & 0.16 \\
\hline $\mathrm{MnO}$ & 3.61 & 3.92 & 3.61 & 3.86 & 3.61 & 3.85 & 3.61 & 3.88 & 3.61 & 3.32 & 3.38 & 3.31 \\
\hline $\mathrm{Na}_{2} \mathrm{O}$ & 15.90 & 16.47 & 11.90 & 12.70 & 9.90 & 10.27 & 7.90 & 8.37 & 6.90 & 7.29 & 12.46 & 12.99 \\
\hline $\mathrm{NiO}$ & 0.53 & 0.49 & 0.53 & 0.52 & 0.53 & 0.53 & 0.53 & 0.49 & 0.53 & 0.53 & 0.49 & 0.53 \\
\hline $\mathrm{P}_{2} \mathrm{O}_{5}$ & 0.72 & 0.84 & 0.72 & 0.85 & 0.72 & 0.83 & 0.72 & 0.82 & 0.72 & 0.86 & 0.67 & 0.75 \\
\hline $\mathrm{PbO}$ & 0.69 & 0.66 & 0.69 & 0.65 & 0.69 & 0.63 & 0.69 & 0.65 & 0.69 & 0.60 & 0.65 & 0.60 \\
\hline $\mathrm{SnO}_{2}$ & 0.08 & 0.09 & 0.08 & 0.09 & 0.08 & 0.09 & 0.08 & 0.09 & 0.08 & 0.10 & 0.07 & 0.11 \\
\hline $\mathrm{SiO}_{2}$ & 32.77 & 32.21 & 36.77 & 35.95 & 35.77 & 35.21 & 36.77 & 36.88 & 28.77 & 29.29 & 38.34 & 37.88 \\
\hline $\mathrm{SrO}$ & 0.22 & 0.21 & 0.22 & 0.21 & 0.22 & 0.21 & 0.22 & 0.21 & 0.22 & 0.20 & 0.20 & 0.19 \\
\hline $\mathrm{ThO}_{2}$ & 0.00 & 0.00 & 0.00 & 0.00 & 0.00 & 0.00 & 0.00 & 0.00 & 0.00 & 0.00 & 0.00 & 0.00 \\
\hline $\mathrm{SO}_{3}$ & 0.24 & 0.15 & 0.24 & 0.12 & 0.24 & 0.13 & 0.24 & 0.12 & 0.24 & 0.18 & 0.23 & 0.21 \\
\hline $\mathrm{V}_{2} \mathrm{O}_{5}$ & 0.00 & 0.00 & 0.00 & 0.00 & 0.00 & 0.00 & 0.00 & 0.00 & 0.00 & 0.00 & 0.00 & 0.00 \\
\hline $\mathrm{ZnO}$ & 0.04 & 0.04 & 0.04 & 0.05 & 0.04 & 0.04 & 0.04 & 0.05 & 0.04 & 0.12 & 0.04 & 0.05 \\
\hline $\mathrm{ZrO}_{2}$ & 1.26 & 1.20 & 1.26 & 1.21 & 1.26 & 1.18 & 1.26 & 1.19 & 1.26 & 1.17 & 1.18 & 1.14 \\
\hline Sum & 100.00 & 99.75 & 100.00 & 99.80 & 100.00 & 99.82 & 100.00 & 99.85 & 100.00 & 99.76 & 100.00 & 99.93 \\
\hline
\end{tabular}

* - Prepared as the baseline slurry feed only for VGF experiments. 
Table 2.5. Target and XRF Analyzed Compositions of Fused Slurry Feeds of High Iron HLW Formulations for C-106/AY-102.

\begin{tabular}{|c|c|c|c|c|c|c|c|c|c|c|c|c|}
\hline Glass ID & \multicolumn{2}{|c|}{ HLW-NG-Fe0 } & \multicolumn{2}{|c|}{ HLW-NG-Fe1 } & \multicolumn{2}{|c|}{ HLW-NG-Fe2 } & \multicolumn{2}{|c|}{ HLW-NG-Fe3 } & \multicolumn{2}{|c|}{ HLW-NG-Fe4 } & \multicolumn{2}{|c|}{ HLW-NG-Fe5 } \\
\hline Feed Sample ID & \multicolumn{2}{|c|}{ F-HLW-NG-Fe0r-G } & \multicolumn{2}{|c|}{ F-HLW-NG-Felr-G } & \multicolumn{2}{|c|}{ F-HLW-NG-Fe2r-G } & \multicolumn{2}{|c|}{ F-HLW-NG-Fe3r-G } & \multicolumn{2}{|c|}{ NGFe4-DHG } & \multicolumn{2}{|c|}{ FE5DHG } \\
\hline $\begin{array}{c}\text { Waste Loading } \\
\text { (wt\%) }\end{array}$ & \multicolumn{2}{|c|}{37} & \multicolumn{2}{|c|}{37} & \multicolumn{2}{|c|}{42} & \multicolumn{2}{|c|}{47} & \multicolumn{2}{|c|}{47} & \multicolumn{2}{|c|}{47} \\
\hline Data type & Target & XRF & Target & $\mathrm{XRF}$ & Target & $\mathrm{XRF}$ & Target & XRF & Target & $\mathrm{XRF}$ & Target & $\mathrm{XRF}$ \\
\hline $\mathrm{Al}_{2} \mathrm{O}_{3}$ & 4.93 & 6.07 & 4.93 & 5.97 & 5.58 & 6.42 & 6.25 & 6.92 & 6.25 & 7.04 & 6.25 & 7.15 \\
\hline $\mathrm{B}_{2} \mathrm{O}_{3}$ & 10.27 & 10.28 & 13.27 & 13.28 & 13.81 & 13.81 & 13.85 & 13.85 & 13.85 & 13.85 & 15.35 & 15.35 \\
\hline $\mathrm{BaO}$ & 0.07 & 0.10 & 0.07 & 0.09 & 0.08 & 0.09 & 0.09 & 0.12 & 0.09 & 0.12 & 0.09 & 0.10 \\
\hline $\mathrm{CaO}$ & 0.46 & 0.56 & 0.46 & 0.56 & 0.52 & 0.60 & 0.58 & 0.67 & 0.58 & 0.63 & 0.58 & 0.63 \\
\hline $\mathrm{CeO}_{2}$ & 0.10 & 0.11 & 0.10 & 0.11 & 0.11 & 0.13 & 0.13 & 0.14 & 0.13 & 0.14 & 0.13 & 0.11 \\
\hline $\mathrm{Cr}_{2} \mathrm{O}_{3}$ & 0.23 & 0.27 & 0.23 & 0.26 & 0.26 & 0.28 & 0.29 & 0.32 & 0.29 & 0.29 & 0.29 & 0.23 \\
\hline $\mathrm{Fe}_{2} \mathrm{O}_{3}$ & 14.14 & 14.18 & 14.14 & 13.95 & 16.01 & 15.55 & 17.92 & 16.98 & 17.92 & 15.88 & 17.92 & 16.52 \\
\hline $\mathrm{La}_{2} \mathrm{O}_{3}$ & 0.08 & 0.00 & 0.08 & 0.00 & 0.09 & 0.00 & 0.10 & 0.00 & 0.10 & 0.00 & 0.10 & 0.11 \\
\hline $\mathrm{Li}_{2} \mathrm{O}$ & 2.64 & 2.65 & 2.64 & 2.65 & 1.55 & 1.55 & 2.06 & 2.06 & 0.06 & 0.06 & 0.06 & 0.06 \\
\hline $\mathrm{MgO}$ & 0.14 & 0.34 & 0.14 & 0.35 & 0.16 & 0.36 & 0.18 & 0.40 & 0.18 & 0.34 & 0.18 & 0.35 \\
\hline $\mathrm{MnO}$ & 2.85 & 2.92 & 2.85 & 2.90 & 3.23 & 3.17 & 3.61 & 3.47 & 3.61 & 3.29 & 3.61 & 3.08 \\
\hline $\mathrm{Na}_{2} \mathrm{O}$ & 12.60 & 11.75 & 12.60 & 12.22 & 14.17 & 13.86 & 13.40 & 14.18 & 14.40 & 14.31 & 15.90 & 15.42 \\
\hline $\mathrm{NiO}$ & 0.42 & 0.39 & 0.42 & 0.40 & 0.47 & 0.42 & 0.53 & 0.48 & 0.53 & 0.40 & 0.53 & 0.46 \\
\hline $\mathrm{P}_{2} \mathrm{O}_{5}$ & 0.57 & 0.61 & 0.57 & 0.64 & 0.64 & 0.69 & 0.72 & 0.84 & 0.72 & 0.74 & 0.72 & 0.82 \\
\hline $\mathrm{PbO}$ & 0.55 & 0.45 & 0.55 & 0.46 & 0.62 & 0.51 & 0.69 & 0.58 & 0.69 & 0.50 & 0.69 & 0.53 \\
\hline $\mathrm{SnO}_{2}$ & 0.06 & 0.07 & 0.06 & 0.07 & 0.07 & 0.07 & 0.08 & 0.08 & 0.08 & 0.08 & 0.08 & 0.09 \\
\hline $\mathrm{SiO}_{2}$ & 47.80 & 47.16 & 45.50 & 44.62 & 41.05 & 40.97 & 37.77 & 37.22 & 37.77 & 39.77 & 35.77 & 37.25 \\
\hline $\mathrm{SrO}$ & 0.17 & 0.16 & 0.17 & 0.16 & 0.19 & 0.18 & 0.22 & 0.20 & 0.22 & 0.19 & 0.22 & 0.19 \\
\hline $\mathrm{SO}_{3}$ & 0.19 & 0.20 & 0.19 & 0.16 & 0.22 & 0.12 & 0.24 & 0.12 & 0.24 & 0.23 & 0.24 & 0.28 \\
\hline $\mathrm{V}_{2} \mathrm{O}_{5}$ & 0.00 & 0.00 & 0.00 & 0.00 & 0.00 & 0.00 & 0.00 & 0.00 & 1.00 & 0.85 & 0.00 & 0.00 \\
\hline $\mathrm{ZnO}$ & 0.73 & 0.64 & 0.03 & 0.04 & 0.03 & 0.04 & 0.04 & 0.04 & 0.04 & 0.04 & 0.04 & 0.04 \\
\hline $\mathrm{ZrO}_{2}$ & 0.99 & 0.91 & 0.99 & 0.90 & 1.13 & 0.97 & 1.26 & 1.11 & 1.26 & 1.01 & 1.26 & 1.06 \\
\hline Sum & 100.00 & 99.86 & 100.00 & 99.78 & 100.00 & 99.78 & 100.00 & 99.78 & 100.00 & 99.76 & 100.00 & 99.93 \\
\hline
\end{tabular}


Table 2.5. Target and XRF Analyzed Compositions of Fused Slurry Feeds of High Iron HLW Formulations for C-106/AY-102 (continued).

\begin{tabular}{|c|c|c|c|c|c|c|c|c|c|c|c|c|}
\hline Glass ID & \multicolumn{2}{|c|}{ HLW-NG-Fe6 } & \multicolumn{2}{|c|}{ HLW-NG-Fe7 } & \multicolumn{2}{|c|}{ HLW-NG-Fe8 } & \multicolumn{2}{|c|}{ HLW-NG-Fe9 } & \multicolumn{2}{|c|}{$\begin{array}{c}\text { HLW-NG- } \\
\text { Fe10 }\end{array}$} & \multicolumn{2}{|c|}{$\begin{array}{l}\text { HLW-NG- } \\
\text { Fell }\end{array}$} \\
\hline Feed Sample ID & \multicolumn{2}{|c|}{ FE6DHG } & \multicolumn{2}{|c|}{ FE7DHG } & \multicolumn{2}{|c|}{ Not Prepared } & \multicolumn{2}{|c|}{ FE9DHG } & \multicolumn{2}{|c|}{ FE10G } & \multicolumn{2}{|c|}{ FE11G } \\
\hline $\begin{array}{l}\text { Waste Loading } \\
(\mathrm{wt} \%)\end{array}$ & \multicolumn{2}{|c|}{47} & \multicolumn{2}{|c|}{47} & \multicolumn{2}{|c|}{47} & \multicolumn{2}{|c|}{47} & \multicolumn{2}{|c|}{47} & \multicolumn{2}{|c|}{44} \\
\hline Data type & Target & XRF & Target & $\mathrm{XRF}$ & Target & $\mathrm{XRF}$ & Target & $\mathrm{XRF}$ & Target & $\mathrm{XRF}$ & Target & $\mathrm{XRF}$ \\
\hline $\mathrm{Al}_{2} \mathrm{O}_{3}$ & 9.25 & 9.77 & 6.25 & 7.52 & 6.25 & - & 6.25 & 7.89 & 6.25 & 7.60 & 5.85 & 7.29 \\
\hline $\mathrm{B}_{2} \mathrm{O}_{3}$ & 15.35 & 15.35 & 16.35 & 16.35 & 18.35 & - & 16.35 & 16.35 & 18.35 & 18.35 & 15.33 & 15.33 \\
\hline $\mathrm{BaO}$ & 0.09 & 0.11 & 0.09 & 0.10 & 0.09 & - & 0.09 & 0.13 & 0.09 & 0.12 & 0.09 & 0.09 \\
\hline $\mathrm{CaO}$ & 0.58 & 0.63 & 0.58 & 0.66 & 0.58 & - & 0.58 & 0.60 & 8.58 & 7.42 & 0.55 & 0.64 \\
\hline $\mathrm{CeO}_{2}$ & 0.13 & 0.11 & 0.13 & 0.10 & 0.13 & - & 0.13 & 0.12 & 0.13 & 0.09 & 0.12 & 0.09 \\
\hline $\mathrm{Cr}_{2} \mathrm{O}_{3}$ & 0.29 & 0.23 & 0.29 & 0.23 & 0.29 & - & 0.29 & 0.24 & 0.29 & 0.23 & 0.27 & 0.24 \\
\hline $\mathrm{Fe}_{2} \mathrm{O}_{3}$ & 17.92 & 15.84 & 17.92 & 16.01 & 17.92 & - & 17.92 & 15.96 & 17.92 & 16.78 & 16.77 & 16.34 \\
\hline $\mathrm{La}_{2} \mathrm{O}_{3}$ & 0.10 & 0.10 & 0.10 & 0.10 & 0.10 & - & 0.10 & 0.13 & 0.10 & 0.10 & 0.10 & 0.12 \\
\hline $\mathrm{Li}_{2} \mathrm{O}$ & 0.06 & 0.06 & 2.06 & 2.06 & 3.06 & - & 2.06 & 2.06 & 5.06 & 5.06 & 3.05 & 3.05 \\
\hline $\mathrm{MgO}$ & 0.18 & 0.36 & 0.18 & 0.37 & 0.18 & - & 0.18 & 0.39 & 0.18 & 0.39 & 0.17 & 0.41 \\
\hline $\mathrm{MnO}$ & 3.61 & 2.90 & 3.61 & 3.03 & 3.61 & - & 3.61 & 3.05 & 3.61 & 3.17 & 3.38 & 3.04 \\
\hline $\mathrm{Na}_{2} \mathrm{O}$ & 15.90 & 16.34 & 11.90 & 11.87 & 9.90 & - & 7.90 & 8.52 & 6.90 & 6.56 & 12.46 & 11.78 \\
\hline $\mathrm{NiO}$ & 0.53 & 0.40 & 0.53 & 0.46 & 0.53 & - & 0.53 & 0.40 & 0.53 & 0.50 & 0.49 & 0.45 \\
\hline $\mathrm{P}_{2} \mathrm{O}_{5}$ & 0.72 & 0.84 & 0.72 & 0.81 & 0.72 & - & 0.72 & 0.82 & 0.72 & 0.82 & 0.67 & 0.74 \\
\hline $\mathrm{PbO}$ & 0.69 & 0.53 & 0.69 & 0.55 & 0.69 & - & 0.69 & 0.53 & 0.69 & 0.56 & 0.65 & 0.55 \\
\hline $\mathrm{SnO}_{2}$ & 0.08 & 0.13 & 0.08 & 0.09 & 0.08 & - & 0.08 & 0.09 & 0.08 & 0.10 & 0.07 & 0.09 \\
\hline $\mathrm{SiO}_{2}$ & 32.77 & 34.56 & 36.77 & 37.83 & 35.77 & - & 36.77 & 38.08 & 28.77 & 30.51 & 38.34 & 38.08 \\
\hline $\mathrm{SrO}$ & 0.22 & 0.18 & 0.22 & 0.18 & 0.22 & - & 0.22 & 0.18 & 0.22 & 0.19 & 0.20 & 0.18 \\
\hline $\mathrm{SO}_{3}$ & 0.24 & 0.31 & 0.24 & 0.28 & 0.24 & - & 0.24 & 0.30 & 0.24 & 0.12 & 0.23 & 0.23 \\
\hline $\mathrm{V}_{2} \mathrm{O}_{5}$ & 0.00 & 0.00 & 0.00 & 0.00 & 0.00 & - & 0.00 & 0.00 & 0.00 & 0.00 & 0.00 & 0.00 \\
\hline $\mathrm{ZnO}$ & 0.04 & 0.04 & 0.04 & 0.04 & 0.04 & - & 0.04 & 0.04 & 0.04 & 0.04 & 0.04 & 0.04 \\
\hline $\mathrm{ZrO}_{2}$ & 1.26 & 1.04 & 1.26 & 1.04 & 1.26 & - & 1.26 & 1.03 & 1.26 & 1.10 & 1.18 & 1.05 \\
\hline Sum & 100.00 & 99.80 & 100.00 & 99.67 & 100.00 & - & 100.00 & 99.84 & 100.00 & 99.80 & 100.00 & 99.80 \\
\hline
\end{tabular}


Table 2.6. Summary of Key Properties of High Iron HLW Formulations for C-106/AY-102.

\begin{tabular}{|c|c|c|c|c|c|c|}
\hline Glass ID & HLW-NG-Fe0 ${ }^{*}$ & HLW-NG-Fe1 & HLW-NG-Fe2 & HLW-NG-Fe3 & HLW-NG-Fe4 & HLW-NG-Fe5 \\
\hline Waste loading $(\mathrm{wt} \%)$ & 37 & 37 & 42 & 47 & 47 & 47 \\
\hline $\mathrm{X} 1$ in Glass As Melted & - & XRD: no Xl & XRD: no Xl & - & - & XRD: no X1 \\
\hline $\mathrm{x} 1 \% @ 950^{\circ} \mathrm{C}$ & - & $0.33\left(\mathrm{sp}^{* 3}\right)$ & $0.65(\mathrm{sp})$ & $2.53(\mathrm{sp})$ & $2.69(\mathrm{sp})$ & $2.9(\mathrm{sp})$ \\
\hline $\mathrm{X} 1 \% @ 900^{\circ} \mathrm{C}$ & - & $0.57(\mathrm{sp})$ & $1.66(\mathrm{sp})$ & $2.98(\mathrm{sp})$ & $\begin{array}{c}2.68 \\
\text { (sp, hematite) }\end{array}$ & $4(\mathrm{sp})$ \\
\hline $\mathrm{X} 1 \% @ 850^{\circ} \mathrm{C}$ & - & $\begin{array}{c}1.52 \\
\text { (sp, hematite) }\end{array}$ & $2.04(\mathrm{sp})$ & $3.64(\mathrm{sp})$ & $\begin{array}{c}3.43 \\
\text { (sp, hematite) }\end{array}$ & 8.8 (magnitite) \\
\hline $\mathrm{X} 1 \% @ 800^{\circ} \mathrm{C}$ & - & 1.8 (sp, hematite) & $2.41(\mathrm{sp})$ & $\begin{array}{c}3.93 \\
\text { (sp, hematite) }\end{array}$ & $\begin{array}{c}4.1 \\
\text { (sp, hematite) }\end{array}$ & $9.6(\mathrm{sp})$ \\
\hline X1 \% of CCC Sample & $0.1(\mathrm{sp})$ & & $4.93(\mathrm{sp})$ & - & - & - \\
\hline 30 min VGF observation & $\begin{array}{l}\text { Dome due to } \\
\text { foaming }\end{array}$ & Fast melting, & $\begin{array}{c}\text { Moderately fast } \\
\text { melting }\end{array}$ & $\begin{array}{l}\text { Dome due to } \\
\text { foaming }\end{array}$ & $\begin{array}{l}\text { Dome due to } \\
\text { foaming }\end{array}$ & $\begin{array}{l}\text { Dome due to } \\
\text { foaming }\end{array}$ \\
\hline $\mathrm{PCT}(\mathrm{B}, \mathrm{g} / \mathrm{L})$ & $0.548^{\$}$ & 0.903 & 0.986 & - & - & - \\
\hline TCLP & $\mathrm{PASS}^{* 2}$ & PASS & PASS & - & - & - \\
\hline $\mathrm{V} / \mathrm{C} @ 1150^{\circ} \mathrm{C}$ & - & & $\begin{array}{l}30.4 \text { poise } \\
0.33 \mathrm{~S} / \mathrm{cm}\end{array}$ & - & - & - \\
\hline $\mathrm{Al}_{2} \mathrm{O}_{3}$ & 4.93 & 4.93 & 5.58 & 6.25 & 6.25 & 6.25 \\
\hline $\mathrm{B}_{2} \mathrm{O}_{3}$ & 10.27 & 13.27 & 13.81 & 13.85 & 13.85 & 15.35 \\
\hline $\mathrm{CaO}$ & 0.46 & 0.46 & 0.52 & 0.58 & 0.58 & 0.58 \\
\hline $\mathrm{Fe}_{2} \mathrm{O}_{3}$ & 14.14 & 14.14 & 16.01 & 17.92 & 17.92 & 17.92 \\
\hline $\mathrm{K}_{2} \mathrm{O}$ & 0.00 & 0.00 & 0.00 & 0.00 & 0.00 & 0.00 \\
\hline $\mathrm{Li}_{2} \mathrm{O}$ & 2.64 & 2.64 & 1.55 & 2.06 & 0.06 & 0.06 \\
\hline $\mathrm{Na}_{2} \mathrm{O}$ & 12.60 & 12.60 & 14.17 & 13.40 & 14.40 & 15.90 \\
\hline $\mathrm{SiO}_{2}$ & 47.80 & 45.50 & 41.05 & 37.77 & 37.77 & 35.77 \\
\hline $\mathrm{V}_{2} \mathrm{O}_{5}$ & 0.00 & 0.00 & 0.00 & 0.00 & 1.00 & 0.00 \\
\hline
\end{tabular}

*. Only slurry feed was made for this formulation

\$ - Data for HLW04-09 from [7]

$\mathrm{sp}=$ Spinel 
Table 2.6. Summary of Key Properties of High Iron HLW Formulations for C-106/AY-102 (continued).

\begin{tabular}{|c|c|c|c|c|c|c|}
\hline Glass ID & HLW-NG-Fe6 & HLW-NG-Fe7 & HLW-NG-Fe8 & HLW-NG-Fe9 & HLW-NG-Fe10 & HLW-NG-Fe11 \\
\hline Waste loading (wt\%) & 47 & 47 & 47 & 47 & 47 & 44 \\
\hline $\mathrm{X} 1$ in Glass As Melted & XRD: trace magnitite & XRD: no xl & XRD: no xl & XRD: trace magnitite & XRD: no xl & XRD: no xl \\
\hline $\mathrm{X} 1 \% @ 950^{\circ} \mathrm{C}$ & $4.5(\mathrm{sp})$ & $3.11(\mathrm{sp})$ & $2.85(\mathrm{sp})$ & $3.58(\mathrm{sp})$ & $2.72(\mathrm{sp})$ & 1.29 (sp) \\
\hline $\mathrm{X} 1 \% @ 900^{\circ} \mathrm{C}$ & $5.2(\mathrm{sp})$ & $4.33(\mathrm{sp})$ & $4.37(\mathrm{sp})$ & $4.92(\mathrm{sp})$ & $3.51(\mathrm{sp})$ & $2.81(\mathrm{sp})$ \\
\hline $\mathrm{X} 1 \% @ 850^{\circ} \mathrm{C}$ & $5.7(\mathrm{sp})$ & $6.00(\mathrm{sp})$ & $7.48(\mathrm{sp})$ & $6.40(\mathrm{sp})$ & $5.13(\mathrm{sp})$ & 3.42 (sp) \\
\hline $\mathrm{X} 1 \% @ 800^{\circ} \mathrm{C}$ & $6.6(\mathrm{sp})$ & $6.75(\mathrm{sp})$ & $6.14(\mathrm{sp})$ & $7.83(\mathrm{sp})$ & $4.81(\mathrm{sp})$ & $3.51(\mathrm{sp})$ \\
\hline $\mathrm{X} 1 \%$ of CCC Sample & & & & $9.06(\mathrm{sp})$ & & \\
\hline 30 min VGF observation & Dome due to foaming & Dome due to foaming & Not tested & Dome due to foaming & Very fast melting & Fast melting \\
\hline $\operatorname{PCT}(B, g / L)$ & & 1.079 & & 1.138 & & \\
\hline TCLP & & PASS & & PASS & & \\
\hline $\mathrm{V} / \mathrm{C} @ 1150^{\circ} \mathrm{C}$ & & & & 26.98 poise $0.21 \mathrm{~S} / \mathrm{cm}$ & & 14.68 poise $0.40 \mathrm{~S} / \mathrm{cm}$ \\
\hline $\mathrm{Al}_{2} \mathrm{O}_{3}$ & 9.25 & 6.25 & 6.25 & 6.25 & 6.25 & 5.85 \\
\hline $\mathrm{B}_{2} \mathrm{O}_{3}$ & 15.35 & 16.35 & 18.35 & 16.35 & 18.35 & 15.33 \\
\hline $\mathrm{CaO}$ & 0.58 & 0.58 & 0.58 & 0.58 & 8.58 & 0.55 \\
\hline $\mathrm{Fe}_{2} \mathrm{O}_{3}$ & 17.92 & 17.92 & 17.92 & 17.92 & 17.92 & 16.77 \\
\hline $\mathrm{K}_{2} \mathrm{O}$ & 0.00 & 0.00 & 0.00 & 4.00 & 0.00 & 0.00 \\
\hline $\mathrm{Li}_{2} \mathrm{O}$ & 0.06 & 2.06 & 3.06 & 2.06 & 5.06 & 3.05 \\
\hline $\mathrm{Na}_{2} \mathrm{O}$ & 15.90 & 11.90 & 9.90 & 7.90 & 6.90 & 12.46 \\
\hline $\mathrm{SiO}_{2}$ & 32.77 & 36.77 & 35.77 & 36.77 & 28.77 & 38.34 \\
\hline $\mathrm{V}_{2} \mathrm{O}_{5}$ & 0.00 & 0.00 & 0.00 & 0.00 & 0.00 & 0.00 \\
\hline
\end{tabular}

$\mathrm{sp}=$ spinel 
Table 2.7. Ranking Definition for Feed Conversion after 30 Minutes in VGF (from [22]).

\begin{tabular}{|l|l|}
\hline 1 & Very Fast, all feed converted \\
\hline 2 & Fast with minor residue on side wall \\
\hline 3 & Moderate with foamy residue on side wall \\
\hline 4 & Slow with thick foam layer \\
\hline 5 & Slow with partially collapsed dome \\
\hline 6 & Very slow with fully developed dome \\
\hline
\end{tabular}

Table 2.8. Viscosity and Electrical Conductivity of Selected High Iron HLW Glasses for C-106/AY-102.

\begin{tabular}{|c|c|c|c|c|c|c|}
\hline \multirow{2}{*}{$\begin{array}{c}\text { Temperature } \\
\left({ }^{\circ} \mathrm{C}\right)\end{array}$} & \multicolumn{2}{|c|}{ HLW-NG-Fe2 } & \multicolumn{2}{c|}{ HLW-NG-Fe9 } & \multicolumn{2}{c|}{ HLW-NG-Fe11 } \\
\cline { 2 - 7 } & $\begin{array}{c}\text { Viscosity } \\
\text { (Poise) }\end{array}$ & $\begin{array}{c}\text { Electrical } \\
\text { Conductivity } \\
\text { (S/cm) }\end{array}$ & $\begin{array}{c}\text { Viscosity } \\
\text { (Poise) }\end{array}$ & $\begin{array}{c}\text { Electrical } \\
\text { Conductivity } \\
\text { (S/cm) }\end{array}$ & $\begin{array}{c}\text { Viscosity } \\
\text { (Poise) }\end{array}$ & $\begin{array}{c}\text { Electrical } \\
\text { Conductivity } \\
\text { (S/cm) }\end{array}$ \\
\hline 1250 & 14.73 & 0.47 & 12.88 & 0.29 & 7.45 & 0.57 \\
\hline 1150 & 30.43 & 0.33 & 26.98 & 0.21 & 14.68 & 0.40 \\
\hline 1050 & 76.68 & 0.23 & 71.20 & 0.13 & 33.99 & 0.27 \\
\hline 950 & 259.13 & 0.14 & 269.24 & 0.07 & 98.71 & 0.17 \\
\hline
\end{tabular}


Table 2.9. 7-Day PCT Leaching Results.

\begin{tabular}{|c|c|c|c|c|c|c|}
\hline $\begin{array}{c}\text { 7-Day PCT } \\
\text { Normalized } \\
\begin{array}{c}\text { Concentrations, } \\
\mathrm{g} / \mathrm{L}\end{array}\end{array}$ & HLW-NG-Fe1 & HLW-NG-Fe2 & HLW-NG-Fe7 & HLW-NG-Fe9 & HLW04-09* & DWPF-EA \\
\hline $\mathrm{B}$ & 0.903 & 0.986 & 1.079 & 1.138 & 0.548 & 16.695 \\
\hline $\mathrm{Li}$ & 0.847 & 0.833 & 0.956 & 0.991 & 0.670 & 9.565 \\
\hline $\mathrm{Na}$ & 0.717 & 0.817 & 0.823 & 0.898 & 0.553 & 13.346 \\
\hline $\mathrm{Si}$ & 0.358 & 0.318 & 0.278 & 0.235 & 0.337 & 3.922 \\
\hline
\end{tabular}


Table 2.10. TCLP Results for the High Iron C-106/AY -102 Glasses and the Associated UTS and Delisting Limits.

\begin{tabular}{|c|c|c|c|c|c|c|c|}
\hline \multirow{2}{*}{ Element } & \multicolumn{5}{|c|}{ Concentration (ppm) of Element in Leachate } & \multirow{2}{*}{$\begin{array}{l}\text { UTS } \\
\text { Limit } \\
(\mathbf{p p m})\end{array}$} & \multirow{2}{*}{$\begin{array}{c}\text { Delisting } \\
\text { Limit } \\
\text { (ppm) }\end{array}$} \\
\hline & $\begin{array}{c}\text { HLW-NG- } \\
\text { Fe1 }\end{array}$ & $\begin{array}{c}\text { HLW-NG- } \\
\text { Fe2 }\end{array}$ & $\begin{array}{c}\text { HLW-NG- } \\
\text { Fe } 7\end{array}$ & $\begin{array}{c}\text { HLW-NG- } \\
\text { Fe9 }\end{array}$ & HLW04-09 ${ }^{\varsigma}$ & & \\
\hline $\mathrm{Ag}$ & $-^{*}$ & - & - & - & $<0.07$ & 0.14 & 3.07 \\
\hline As & - & - & - & - & - & 5 & 3.08 \\
\hline $\mathrm{Ba}$ & 0.63 & 0.68 & 0.64 & 0.7 & 0.12 & 21 & 100 \\
\hline $\mathrm{Cd}$ & - & - & - & - & $<0.03$ & 0.11 & 0.48 \\
\hline $\mathrm{Cr}$ & 0.02 & 0.02 & 0.03 & 0.03 & $<0.01$ & 0.6 & 5 \\
\hline $\mathrm{Cu}$ & - & - & - & - & 0.1 & NA & 29200 \\
\hline $\mathrm{Ni}$ & 0.06 & 0.1 & 0.09 & 0.08 & 0.06 & 11 & 12.1 \\
\hline $\mathrm{Pb}$ & 0.01 & 0.12 & 0.14 & 0.15 & $<0.10$ & 0.75 & 5 \\
\hline $\mathrm{Sb}$ & - & - & - & - & $<0.50$ & 1.15 & 0.659 \\
\hline $\mathrm{Se}$ & - & - & - & - & - & 5.7 & 1 \\
\hline $\mathrm{Tl}$ & - & - & - & - & - & 0.2 & 0.282 \\
\hline $\mathrm{Zn}$ & $\mathrm{NAL}^{\#}$ & NAL & NAL & NAL & 0.24 & $\mathrm{NA}^{*}$ & 225 \\
\hline
\end{tabular}

- Indicates element not present in the glass

* - NA=Not applicable

$\#$ - NAL $=$ Not Analyzed

$\$$ - From [7] 
Table 3.1. Summary of Results from DM100 Tests with High Iron, C-106/AY-102 Waste and Optimized Glass Composition.

\begin{tabular}{|c|c|c|c|}
\hline \multicolumn{2}{|r|}{ Test } & $\begin{array}{l}\text { Optimized } \\
\text { Bubbling }\end{array}$ & $\begin{array}{l}\text { Fixed Bubbling } \\
\qquad(9 \mathrm{lpm})\end{array}$ \\
\hline \multirow{3}{*}{$\stackrel{\Xi}{\Xi}$} & Feed Start & $12 / 7 / 1120: 15$ & $1 / 3 / 12 \quad 14: 42$ \\
\hline & Feed End & $12 / 10 / 112: 00$ & $1 / 5 / 1217: 45$ \\
\hline & Interval & $53.75 \mathrm{hr}$ & $51.05 \mathrm{hr}$ \\
\hline \multicolumn{2}{|c|}{ Water Feeding for Cold Cap } & $45 \mathrm{~min}$ & $58 \mathrm{~min}$ \\
\hline \multicolumn{2}{|r|}{ Slurry Feeding } & $53.0 \mathrm{hr}$ & $50.1 \mathrm{hr}$ \\
\hline \multicolumn{2}{|c|}{ Feeding Interruptions } & $108 \mathrm{~min}$ & $31 \mathrm{~min}$ \\
\hline \multicolumn{2}{|c|}{ Average Bubbling Rate } & $13.21 \mathrm{pm}$ & $8.91 \mathrm{pm}$ \\
\hline \multirow{4}{*}{ 芯 } & Used & $1039 \mathrm{~kg}$ & $1004 \mathrm{~kg}$ \\
\hline & \multirow{2}{*}{ Target Glass yield } & $500 \mathrm{~g} / 1$ & $500 \mathrm{~g} / 1$ \\
\hline & & $0.368 \mathrm{~kg} / \mathrm{kg}$ & $0.368 \mathrm{~kg} / \mathrm{kg}$ \\
\hline & Average Feed Rate & $19.6 \mathrm{~kg} / \mathrm{hr}$ & $19.7 \mathrm{~kg} / \mathrm{hr}$ \\
\hline \multirow{5}{*}{ 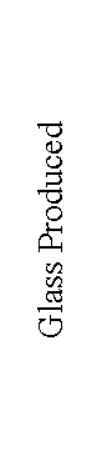 } & Poured & $379 \mathrm{~kg}$ & $371 \mathrm{~kg}$ \\
\hline & $\begin{array}{c}\text { Average Rate based } \\
\text { on glass poured }\end{array}$ & $1589 \mathrm{~kg} / \mathrm{m}^{2} /$ day & $1645 \mathrm{~kg} / \mathrm{m}^{2} /$ day \\
\hline & $\begin{array}{l}\text { Average Rate based } \\
\text { on feed consumed }\end{array}$ & $1606 \mathrm{~kg} / \mathrm{m}^{2} /$ day & $1649 \mathrm{~kg} / \mathrm{m}^{2} /$ day \\
\hline & Steady State Rate ${ }^{*}$ & $1900 \mathrm{~kg} / \mathrm{m}^{2} /$ day & $1650 \mathrm{~kg} / \mathrm{m}^{2} /$ day \\
\hline & Average Power Use & $\begin{array}{l}3.6 \mathrm{~kW} \mathrm{hr} / \mathrm{kg} \\
\text { glass }\end{array}$ & $\begin{array}{c}3.5 \mathrm{~kW} \mathrm{hr} / \mathrm{kg} \\
\text { glass }\end{array}$ \\
\hline
\end{tabular}

*: Rates estimated from feed data.

Note: Rates do not take into account the time for water feeding and cold cap burn-off. 
Table 3.2. Steady-State Production Rates Achieved on the DM100 Melter with High Iron, C-106/AY-102 Waste with New (HLW-NG-Fe2) and Baseline (HLW04-09) Glass

Compositions at $1150^{\circ} \mathrm{C}$.

\begin{tabular}{|c|c|c|c|c|c|}
\hline HLW Waste & $\begin{array}{l}\text { Feed Solids } \\
\text { Content } \\
\text { (g glass/liter) }\end{array}$ & $\begin{array}{c}\text { Waste } \\
\text { Loading } \\
\text { (Wt\% } \\
\text { Oxide) }\end{array}$ & $\begin{array}{l}\text { Melt Pool } \\
\text { Bubbling } \\
\text { (Ipm) }\end{array}$ & $\begin{array}{c}\text { Glass } \\
\text { Production } \\
\text { Rate } \\
\left(\mathrm{kg} / \mathrm{m}^{2} / \mathrm{day}\right) \\
\end{array}$ & $\begin{array}{c}\text { Waste Oxide } \\
\text { Processing } \\
\text { Rate } \\
\left(\mathrm{kg} / \mathrm{m}^{2} / \mathrm{day}\right)\end{array}$ \\
\hline New Glass Composition & 500 & 42.0 & $\begin{array}{l}\text { Optimized, } \\
13.2\end{array}$ & 1900 & 798 \\
\hline New Glass Composition & 500 & 42.0 & 8.9 & 1650 & 693 \\
\hline HLW04-09 [15] & 420 & 37.10 & $\begin{array}{c}\text { Optimized, } \\
11.3 \\
\end{array}$ & 1350 & 501 \\
\hline HLW04-09 [12] & 435 & 37.10 & 8.9 & 1100 & 408 \\
\hline $\begin{array}{l}\text { HLW04-09, Adjusted } \\
\text { Rheology Feed [12] }\end{array}$ & 436 & 37.10 & 9.1 & 1150 & 427 \\
\hline $\begin{array}{l}\text { HLW04-09, Feed made } \\
\text { from HLW SIPP [12] }\end{array}$ & 500 & 37.10 & 9.1 & 1200 & 445 \\
\hline
\end{tabular}


Table 3.3. Summary of Measured DM100 Parameters.

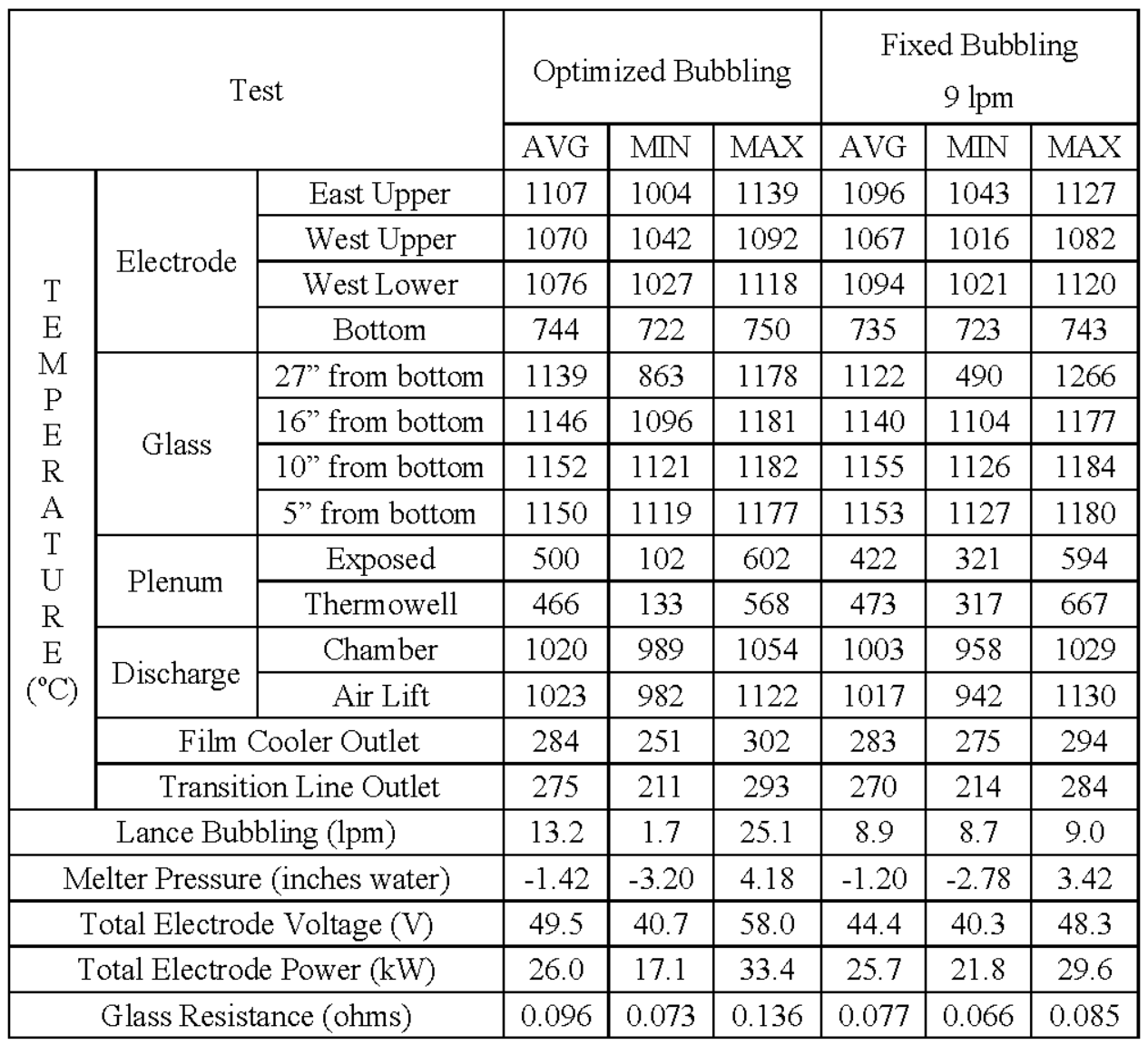


Table 4.1. Characteristics of Melter Feed Samples with High Iron, C-106/AY-102 Waste and Optimized Glass Composition.

\begin{tabular}{|c|c|c|c|c|c|c|c|c|}
\hline \multirow{3}{*}{ Sampling Date } & \multirow{3}{*}{ Sample Name } & \multirow{3}{*}{$\%$ Water } & \multirow{3}{*}{$\mathbf{p H}$} & \multirow{3}{*}{$\begin{array}{c}\text { Density } \\
(\mathrm{g} / \mathrm{ml})\end{array}$} & \multicolumn{4}{|c|}{ Glass Yield } \\
\hline & & & & & \multirow{2}{*}{$(\mathrm{g} / \mathrm{l})$} & Measured & Target & \multirow{2}{*}{ \%Dev. } \\
\hline & & & & & & $(\mathrm{kg} / \mathrm{kg})$ & $(\mathrm{kg} / \mathrm{kg})$ & \\
\hline $12 / 7 / 2011$ & JBL-F-83A & 57.40 & 10.95 & 1.40 & 524 & 0.374 & 0.369 & -1.44 \\
\hline $12 / 11 / 2011$ & JBL-F-114A & 55.97 & 11.40 & 1.41 & 538 & 0.382 & 0.369 & -3.39 \\
\hline $1 / 5 / 2012$ & KBL-F-11A & 55.79 & 11.45 & 1.46 & 570 & 0.390 & 0.369 & -5.72 \\
\hline
\end{tabular}


Table 4.2. XRF Analyzed Compositions of Vitrified Melter Feed Samples (wt\%).

\begin{tabular}{|c|c|c|c|c|c|c|}
\hline Constituent & Target & JBL-F-83A & $\begin{array}{c}\text { JBL-F- } \\
114 A\end{array}$ & $\begin{array}{c}\text { KBL-F- } \\
11 \mathrm{~A}\end{array}$ & Average & \% Dev. \\
\hline $\mathrm{Al}_{2} \mathrm{O}_{3}$ & 5.58 & 5.87 & 6.08 & 5.77 & 5.91 & 5.81 \\
\hline $\mathrm{B}_{2} \mathrm{O}_{3}$ & 13.81 & $13.97^{*}$ & $15.73^{*}$ & $15.88^{*}$ & 15.19 & 9.98 \\
\hline $\mathrm{BaO}$ & 0.08 & 0.10 & 0.12 & 0.12 & 0.12 & $\mathrm{NC}$ \\
\hline $\mathrm{Bi}_{2} \mathrm{O}_{3}$ & $\S$ & $<0.01$ & $<0.01$ & $<0.01$ & $<0.01$ & $\mathrm{NC}$ \\
\hline $\mathrm{CaO}$ & 0.52 & 0.54 & 0.59 & 0.55 & 0.56 & $\mathrm{NC}$ \\
\hline $\mathrm{CdO}$ & $\S$ & 0.02 & 0.02 & 0.03 & 0.02 & $\mathrm{NC}$ \\
\hline $\mathrm{Ce}_{2} \mathrm{O}_{3}$ & 0.11 & 0.10 & 0.10 & 0.07 & 0.09 & $\mathrm{NC}$ \\
\hline $\mathrm{Cr}_{2} \mathrm{O}_{3}$ & 0.25 & 0.20 & 0.21 & 0.20 & 0.20 & $\mathrm{NC}$ \\
\hline $\mathrm{Cs}_{2} \mathrm{O}$ & $\S$ & $<0.01$ & $<0.01$ & $<0.01$ & $<0.01$ & $\mathrm{NC}$ \\
\hline $\mathrm{Fe}_{2} \mathrm{O}_{3}$ & 16.01 & 15.45 & 17.09 & 15.60 & 16.03 & 0.19 \\
\hline $\mathrm{K}_{2} \mathrm{O}$ & $\S$ & 0.36 & 0.28 & 0.27 & 0.30 & $\mathrm{NC}$ \\
\hline $\mathrm{La}_{2} \mathrm{O}_{3}$ & 0.09 & 0.07 & 0.09 & 0.09 & 0.08 & $\mathrm{NC}$ \\
\hline $\mathrm{Li}_{2} \mathrm{O}$ & 1.55 & $1.49 *$ & $1.48 *$ & $1.48 *$ & 1.48 & 4.52 \\
\hline $\mathrm{MgO}$ & 0.17 & 0.27 & 0.33 & 0.30 & 0.30 & $\mathrm{NC}$ \\
\hline $\mathrm{MnO}$ & 3.22 & 2.26 & 2.59 & 2.54 & 2.46 & -23.52 \\
\hline $\mathrm{Na}_{2} \mathrm{O}$ & 14.16 & 13.71 & 14.79 & 15.62 & 14.71 & 3.83 \\
\hline $\mathrm{Nd}_{2} \mathrm{O}_{3}$ & $\S$ & $<0.01$ & $<0.01$ & $<0.01$ & $<0.01$ & $\mathrm{NC}$ \\
\hline $\mathrm{NiO}$ & 0.47 & 0.41 & 0.50 & 0.43 & 0.45 & $\mathrm{NC}$ \\
\hline $\mathrm{P}_{2} \mathrm{O}_{5}$ & 0.64 & 0.62 & 0.63 & 0.60 & 0.62 & $\mathrm{NC}$ \\
\hline $\mathrm{PbO}$ & 0.62 & 0.45 & 0.52 & 0.49 & 0.48 & $\mathrm{NC}$ \\
\hline $\mathrm{SiO}_{2}$ & 41.06 & 42.59 & 37.18 & 38.38 & 39.36 & -4.09 \\
\hline $\mathrm{SnO}_{2}$ & 0.07 & 0.08 & 0.09 & 0.11 & 0.09 & $\mathrm{NC}$ \\
\hline $\mathrm{SO}_{3}$ & 0.22 & 0.32 & 0.23 & 0.27 & 0.27 & $\mathrm{NC}$ \\
\hline $\mathrm{SrO}$ & 0.20 & 0.15 & 0.18 & 0.15 & 0.16 & $\mathrm{NC}$ \\
\hline $\mathrm{TiO}_{2}$ & $\S$ & 0.08 & 0.08 & 0.08 & 0.08 & $\mathrm{NC}$ \\
\hline $\mathrm{V}_{2} \mathrm{O}_{3}$ & $\S$ & $<0.01$ & $<0.01$ & $<0.01$ & $<0.01$ & $\mathrm{NC}$ \\
\hline $\mathrm{ZnO}$ & 0.03 & 0.06 & 0.07 & 0.07 & 0.07 & $\mathrm{NC}$ \\
\hline $\mathrm{ZrO}_{2}$ & 1.12 & 0.85 & 1.03 & 0.89 & 0.92 & -17.82 \\
\hline Sum & 100.00 & 100.00 & 100.00 & 100.00 & 100.00 & $\mathrm{NC}$ \\
\hline
\end{tabular}

$\S$ - Not a target constituent

* - DCP-AES measured values

$\mathrm{NC}-$ Not calculated 
Table 4.3. Comparison of XRF and DCP Analyzed Compositions of Vitrified Melter Feed Samples (wt\%).

\begin{tabular}{|c|c|c|c|c|c|c|c|}
\hline \multirow{2}{*}{ Constituent } & \multirow{2}{*}{ Target } & \multicolumn{2}{|c|}{ JBL-F-83A } & \multicolumn{2}{|c|}{ JBL-F-114A } & \multicolumn{2}{|c|}{ KBL-F-11A } \\
\hline & & XRF & DCP & XRF & DCP & XRF & $\overline{D C P}$ \\
\hline $\mathrm{Al}_{2} \mathrm{O}_{3}$ & 5.58 & 5.87 & 5.72 & 6.08 & 6.08 & 5.77 & 5.67 \\
\hline $\mathrm{B}_{2} \mathrm{O}_{3}$ & 13.81 & $13.97^{*}$ & 13.97 & $15.73^{*}$ & 15.73 & $15.88^{*}$ & 15.88 \\
\hline $\mathrm{BaO}$ & 0.08 & 0.10 & 0.11 & 0.12 & 0.12 & 0.12 & 0.12 \\
\hline $\mathrm{Bi}_{2} \mathrm{O}_{3}$ & $\S$ & $<0.01$ & NA & $<0.01$ & NA & $<0.01$ & $\mathrm{NA}$ \\
\hline $\mathrm{CaO}$ & 0.52 & 0.54 & 0.62 & 0.59 & 0.67 & 0.55 & 0.65 \\
\hline $\mathrm{CdO}$ & $\S$ & 0.02 & 0.02 & 0.02 & 0.02 & 0.03 & 0.02 \\
\hline $\mathrm{Ce}_{2} \mathrm{O}_{3}$ & 0.11 & 0.10 & $\mathrm{NA}$ & 0.10 & $\mathrm{NA}$ & 0.07 & $\mathrm{NA}$ \\
\hline $\mathrm{Cr}_{2} \mathrm{O}_{3}$ & 0.25 & 0.20 & 0.22 & 0.21 & 0.24 & 0.20 & 0.23 \\
\hline $\mathrm{Cs}_{2} \mathrm{O}$ & $\S$ & $<0.01$ & $\mathrm{NA}$ & $<0.01$ & $\mathrm{NA}$ & $<0.01$ & NA \\
\hline $\mathrm{Fe}_{2} \mathrm{O}_{3}$ & 16.01 & 15.45 & 15.42 & 17.09 & 15.81 & 15.60 & 15.57 \\
\hline $\mathrm{K}_{2} \mathrm{O}$ & $\S$ & 0.36 & 0.61 & 0.28 & 0.59 & 0.27 & 0.61 \\
\hline $\mathrm{La}_{2} \mathrm{O}_{3}$ & 0.09 & 0.07 & NA & 0.09 & NA & 0.09 & NA \\
\hline $\mathrm{Li}_{2} \mathrm{O}$ & 1.55 & $1.49 *$ & 1.49 & $1.48 *$ & 1.48 & $1.48^{*}$ & 1.48 \\
\hline $\mathrm{MgO}$ & 0.17 & 0.27 & 0.36 & 0.33 & 0.38 & 0.30 & 0.37 \\
\hline $\mathrm{MnO}$ & 3.22 & 2.26 & 2.40 & 2.59 & 2.62 & 2.54 & 2.67 \\
\hline $\mathrm{Na}_{2} \mathrm{O}$ & 14.16 & 13.71 & 11.68 & 14.79 & 12.78 & 15.62 & 12.37 \\
\hline $\mathrm{Nd}_{2} \mathrm{O}_{3}$ & $\S$ & $<0.01$ & NA & $<0.01$ & $\mathrm{NA}$ & $<0.01$ & $\mathrm{NA}$ \\
\hline $\mathrm{NiO}$ & 0.47 & 0.41 & 0.41 & 0.50 & 0.42 & 0.43 & 0.40 \\
\hline$\overline{\mathrm{P}_{2} \mathrm{O}_{5}}$ & 0.64 & 0.62 & 0.62 & 0.63 & 0.57 & 0.60 & 0.63 \\
\hline $\mathrm{PbO}$ & 0.62 & 0.45 & 0.58 & 0.52 & 0.58 & 0.49 & 0.64 \\
\hline $\mathrm{SiO}_{2}$ & 41.06 & 42.59 & 42.47 & 37.18 & 37.55 & 38.39 & 36.90 \\
\hline $\mathrm{SnO}_{2}$ & 0.07 & 0.08 & 0.02 & 0.09 & $<0.01$ & 0.11 & 0.10 \\
\hline $\mathrm{SO}_{3}$ & 0.22 & 0.32 & NA & 0.23 & $\mathrm{NA}$ & 0.27 & $\mathrm{NA}$ \\
\hline $\mathrm{SrO}$ & 0.20 & 0.15 & 0.19 & 0.18 & 0.21 & 0.15 & 0.20 \\
\hline $\mathrm{TiO}_{2}$ & $\S$ & 0.08 & 0.09 & 0.08 & 0.09 & 0.08 & 0.09 \\
\hline $\mathrm{V}_{2} \mathrm{O}_{3}$ & $\S$ & $<0.01$ & 0.01 & $<0.01$ & 0.01 & $<0.01$ & $<0.01$ \\
\hline $\mathrm{ZnO}$ & 0.03 & 0.06 & 0.08 & 0.07 & 0.08 & 0.07 & 0.07 \\
\hline $\mathrm{ZrO}_{2}$ & 1.12 & 0.85 & 1.03 & 1.03 & 1.12 & 0.89 & 1.04 \\
\hline Sum & 100.00 & 100.00 & 98.12 & 100.00 & 97.15 & 100.00 & 95.71 \\
\hline
\end{tabular}


Table 4.4. Listing of Glass Discharged, Masses, and Analysis Performed.

\begin{tabular}{|c|c|c|c|c|c|}
\hline Test & Date & Name & Analysis & Mass kg) & Cumulative Mass (kg) \\
\hline \multirow{25}{*}{$\begin{array}{c}\text { Optimized } \\
\text { Bubbling }\end{array}$} & \multirow{2}{*}{$12 / 7 / 11$} & JBL-G-85A & $\mathrm{XRF}, \mathrm{DCP}$ & 37.78 & 37.78 \\
\hline & & JBL-G-85B & - & - & - \\
\hline & \multirow{9}{*}{$12 / 8 / 11$} & JBL-G-85C & XRF & 18.86 & 56.64 \\
\hline & & JBL-G-88A & - & - & - \\
\hline & & JBL-G-88B & $\mathrm{XRF}$ & 25.34 & 81.98 \\
\hline & & JBL-G-89A & - & - & - \\
\hline & & JBL-G-92A & XRF & 21.92 & 103.90 \\
\hline & & JBL-G-93A & - & - & - \\
\hline & & JBL-G-93B & XRF,DCP & 32.14 & 136.04 \\
\hline & & JBL-G-99A & - & - & - \\
\hline & & JBL-G-101A & $\mathrm{XRF}$ & 33.16 & 169.20 \\
\hline & \multirow{11}{*}{$12 / 9 / 11$} & JBL-G-102A & - & - & - \\
\hline & & JBL-G-102B & $\mathrm{XRF}$ & 33.00 & 202.20 \\
\hline & & JBL-G-103A & - & - & - \\
\hline & & JBL-G-107A & $\mathrm{XRF}$ & 36.37 & 238.57 \\
\hline & & JBL-G-107B & - & - & - \\
\hline & & JBL-G-108A & XRF,DCP & 47.88 & 286.45 \\
\hline & & JBL-G-109A & - & - & - \\
\hline & & JBL-G-109B & $\mathrm{XRF}$ & 27.64 & 314.09 \\
\hline & & JBL-G-113A & - & - & - \\
\hline & & JBL-G-113B & $\mathrm{XRF}$ & 19.88 & 333.97 \\
\hline & & JBL-G-113C & - & - & - \\
\hline & \multirow{3}{*}{$12 / 10 / 11$} & JBL-G-114A & $\mathrm{XRF}$ & 22.36 & 356.33 \\
\hline & & JBL-G-114B & - & - & - \\
\hline & & JBL-G-114C & XRF,DCP,TCLP,PCT,SEM & 22.54 & 378.87 \\
\hline \multirow{14}{*}{$\begin{array}{c}\text { Fixed } \\
\text { Bubbling } \\
(9 \mathrm{lpm})\end{array}$} & \multirow{4}{*}{$1 / 3 / 12$} & JBL-G-129A & - & - & - \\
\hline & & JBL-G-131A & $\mathrm{XRF}$ & 25.00 & 403.87 \\
\hline & & JBL-G-131B & - & - & - \\
\hline & & JBL-G-131C & XRF,DCP & 22.02 & 425.89 \\
\hline & \multirow{10}{*}{$1 / 4 / 12$} & JBL-G-132A & - & - & - \\
\hline & & JBL-G-136A & $\mathrm{XRF}$ & 21.05 & 446.94 \\
\hline & & JBL-G-136B & - & - & - \\
\hline & & JBL-G-136C & $\mathrm{XRF}$ & 12.65 & 459.59 \\
\hline & & JBL-G-137A & - & - & - \\
\hline & & JBL-G-137B & $\mathrm{XRF}$ & 27.16 & 486.75 \\
\hline & & JBL-G-137C & - & - & - \\
\hline & & JBL-G-138A & $\mathrm{XRF}$ & 21.02 & 507.77 \\
\hline & & JBL-G-138B & - & - & - \\
\hline & & JBL-G-138C & XRF,DCP & 15.76 & 523.53 \\
\hline
\end{tabular}

- Empty data field 
Table 4.4. List of Glass Discharged, Masses, and Analysis Performed (continued).

\begin{tabular}{|c|c|c|c|c|c|}
\hline Test & Date & Name & Analysis & Mass (kg) & Cumulative Mass (kg) \\
\hline \multirow{18}{*}{$\begin{array}{c}\text { Fixed } \\
\text { Bubbling } \\
\text { (9 lpm) }\end{array}$} & \multirow{6}{*}{$1 / 4 / 12$} & JBL-G-142A & - & - & - \\
\hline & & JBL-G-142B & $\mathrm{XRF}$ & 25.10 & 548.63 \\
\hline & & JBL-G-142C & - & - & - \\
\hline & & JBL-G-143A & $\mathrm{XRF}$ & 28.70 & 577.33 \\
\hline & & JBL-G-143B & - & - & - \\
\hline & & JBL-G-143C & $\mathrm{XRF}$ & 28.40 & 605.73 \\
\hline & \multirow{12}{*}{$1 / 5 / 12$} & JBL-G-147A & - & - & - \\
\hline & & JBL-G-148A & XRF,DCP & 25.90 & 631.63 \\
\hline & & JBL-G-148B & - & - & - \\
\hline & & JBL-G-150A & $\mathrm{XRF}$ & 20.30 & 651.93 \\
\hline & & JBL-G-150B & - & - & - \\
\hline & & JBL-G-150C & $\mathrm{XRF}$ & 20.68 & 672.61 \\
\hline & & JBL-G-150D & - & - & - \\
\hline & & JBL-G-151A & $\mathrm{XRF}$ & 22.54 & 695.15 \\
\hline & & JBL-G-151B & - & - & - \\
\hline & & JBL-G-151C & $\mathrm{XRF}$ & 18.66 & 713.81 \\
\hline & & KBL-G-11A & - & - & - \\
\hline & & KBL-G-11B & XRF,DCP,TCLP,PCT,SEM & 36.42 & 750.23 \\
\hline
\end{tabular}

- Empty data field 
Table 4.5. XRF Analyzed Composition for Glass Discharged During DM100 Melter Tests (wt\%).

\begin{tabular}{|c|c|c|c|c|c|c|c|c|c|c|}
\hline \multirow{2}{*}{\multicolumn{2}{|c|}{$\begin{array}{c}\text { Test } \\
\text { Glass }(\mathrm{kg})\end{array}$}} & \multicolumn{9}{|c|}{ Optimized Bubbling } \\
\hline & & 37.78 & 56.64 & 81.98 & 103.90 & 136.04 & 169.20 & 202.20 & 238.57 & 286.45 \\
\hline Constituent & Target & $\begin{array}{c}\text { JBL-G- } \\
85 \mathrm{~A}\end{array}$ & $\begin{array}{c}\text { JBL-G- } \\
85 \mathrm{C}\end{array}$ & \begin{tabular}{|c} 
JBL-G- \\
$88 \mathrm{~B}$ \\
\end{tabular} & $\begin{array}{c}\text { JBL-G- } \\
92 \mathrm{~A}\end{array}$ & $\begin{array}{c}\text { JBL-G- } \\
93 \mathrm{~B} \\
\end{array}$ & $\begin{array}{c}\text { JBL-G- } \\
101 \mathrm{~A}\end{array}$ & $\begin{array}{c}\text { JBL-G- } \\
102 B\end{array}$ & $\begin{array}{c}\text { JBL-G- } \\
107 \mathrm{~A}\end{array}$ & $\begin{array}{r}\text { JBL-G- } \\
108 \mathrm{~A}\end{array}$ \\
\hline $\mathrm{Al}_{2} \mathrm{O}_{3}$ & 5.58 & 7.35 & 7.30 & 6.87 & 6.70 & 6.44 & 6.26 & 6.26 & 6.32 & 6.29 \\
\hline $\mathrm{B}_{2} \mathrm{O}_{3}$ & 13.81 & $11.80^{\#}$ & 11.95 & 12.15 & 12.32 & $12.57^{\#}$ & 12.84 & 13.12 & 13.42 & $13.81^{\#}$ \\
\hline $\mathrm{BaO}$ & 0.08 & 0.09 & 0.10 & 0.08 & 0.09 & 0.10 & 0.13 & 0.10 & 0.12 & 0.11 \\
\hline $\mathrm{Bi}_{2} \mathrm{O}_{3}$ & $\S$ & 0.21 & 0.20 & 0.18 & 0.14 & 0.10 & 0.09 & 0.08 & 0.06 & 0.05 \\
\hline $\mathrm{CaO}$ & 0.52 & 0.81 & 0.76 & 0.74 & 0.73 & 0.70 & 0.65 & 0.66 & 0.62 & 0.62 \\
\hline $\mathrm{CdO}$ & $\S$ & 0.21 & 0.19 & 0.18 & 0.15 & 0.11 & 0.11 & 0.08 & 0.07 & 0.07 \\
\hline $\mathrm{Ce}_{2} \mathrm{O}_{3}$ & 0.11 & 0.11 & 0.12 & 0.14 & 0.09 & 0.06 & 0.16 & 0.10 & 0.09 & 0.10 \\
\hline $\mathrm{Cr}_{2} \mathrm{O}_{3}$ & 0.25 & 0.28 & 0.29 & 0.27 & 0.28 & 0.28 & 0.24 & 0.22 & 0.24 & 0.24 \\
\hline $\mathrm{Cs}_{2} \mathrm{O}$ & $\S$ & 0.03 & 0.02 & $<0.01$ & $<0.01$ & $<0.01$ & $<0.01$ & $<0.01$ & $<0.01$ & $<0.01$ \\
\hline $\mathrm{Fe}_{2} \mathrm{O}_{3}$ & 16.01 & 13.44 & 13.48 & 14.33 & 14.55 & 14.92 & 15.19 & 15.76 & 16.17 & 16.38 \\
\hline $\mathrm{K}_{2} \mathrm{O}$ & $\S$ & 0.50 & 0.40 & 0.42 & 0.35 & 0.47 & 0.34 & 0.32 & 0.32 & 0.40 \\
\hline $\mathrm{La}_{2} \mathrm{O}_{3}$ & 0.09 & 0.11 & 0.12 & 0.13 & 0.13 & 0.08 & 0.13 & 0.09 & 0.12 & 0.07 \\
\hline $\mathrm{Li}_{2} \mathrm{O}$ & 1.55 & $2.18^{\#}$ & 2.08 & 1.95 & 1.84 & $1.67^{\#}$ & 1.64 & 1.60 & 1.57 & $1.52^{\#}$ \\
\hline $\mathrm{MgO}$ & 0.17 & 0.25 & 0.28 & 0.28 & 0.30 & 0.27 & 0.30 & 0.30 & 0.30 & 0.30 \\
\hline $\mathrm{MnO}$ & 3.22 & 2.01 & 2.01 & 2.19 & 2.35 & 2.54 & 2.51 & 2.59 & 2.52 & 2.54 \\
\hline $\mathrm{Na}_{2} \mathrm{O}$ & 14.16 & 12.51 & 12.29 & 12.11 & 12.67 & 12.73 & 13.11 & 12.86 & 13.96 & 13.73 \\
\hline $\mathrm{Nd}_{2} \mathrm{O}_{3}$ & $\S$ & 0.07 & 0.04 & $<0.01$ & 0.04 & 0.06 & 0.03 & 0.02 & 0.02 & $<0.01$ \\
\hline $\mathrm{NiO}$ & 0.47 & 0.43 & 0.46 & 0.45 & 0.44 & 0.45 & 0.44 & 0.46 & 0.44 & 0.46 \\
\hline $\mathrm{P}_{2} \mathrm{O}_{5}$ & 0.64 & 0.69 & 0.68 & 0.67 & 0.65 & 0.63 & 0.62 & 0.64 & 0.60 & 0.60 \\
\hline $\mathrm{PbO}$ & 0.62 & 0.40 & 0.41 & 0.43 & 0.46 & 0.50 & 0.50 & 0.52 & 0.50 & 0.50 \\
\hline $\mathrm{SiO}_{2}$ & 41.06 & 43.97 & 44.29 & 44.04 & 43.41 & 43.13 & 42.66 & 42.10 & 40.51 & 40.26 \\
\hline $\mathrm{SnO}_{2}$ & 0.07 & 0.12 & 0.11 & 0.10 & 0.10 & 0.10 & 0.10 & 0.09 & 0.12 & 0.09 \\
\hline $\mathrm{SO}_{3}$ & 0.22 & 0.32 & 0.35 & 0.35 & 0.36 & 0.36 & 0.33 & 0.35 & 0.35 & 0.33 \\
\hline $\mathrm{SrO}$ & 0.20 & 0.13 & 0.13 & 0.14 & 0.14 & 0.15 & 0.15 & 0.15 & 0.16 & 0.16 \\
\hline $\mathrm{TiO}_{2}$ & $\S$ & 0.09 & 0.09 & 0.09 & 0.08 & 0.07 & 0.08 & 0.08 & 0.09 & 0.08 \\
\hline $\mathrm{V}_{2} \mathrm{O}_{3}$ & $\S$ & 0.12 & 0.11 & 0.08 & 0.08 & 0.07 & 0.05 & 0.04 & 0.03 & 0.03 \\
\hline $\mathrm{ZnO}$ & 0.03 & 0.28 & 0.27 & 0.24 & 0.23 & 0.20 & 0.18 & 0.16 & 0.15 & 0.13 \\
\hline $\mathrm{ZrO}_{2}$ & 1.12 & 1.50 & 1.45 & 1.38 & 1.32 & 1.24 & 1.16 & 1.18 & 1.13 & 1.13 \\
\hline Sum & 100.00 & 100.00 & 100.00 & 100.00 & 100.00 & 100.00 & 100.00 & 100.00 & 100.00 & 100.00 \\
\hline
\end{tabular}

$\S$ - Not a target constituent

\# - $\mathrm{B}_{2} \mathrm{O}_{3}$ and $\mathrm{Li}_{2} \mathrm{O}$ were measured by DCP-AES, values for other samples calculated by interpolation 
Table 4.5. XRF Analyzed Composition for Glass Discharged During DM100 Melter Tests (wt\%) (continued).

\begin{tabular}{|c|c|c|c|c|c|c|c|c|c|c|}
\hline \multirow{2}{*}{\multicolumn{2}{|c|}{$\begin{array}{c}\text { Test } \\
\text { Glass (kg) }\end{array}$}} & \multicolumn{4}{|c|}{ Optimized Bubbling } & \multicolumn{5}{|c|}{ Fixed Bubbling (9 lpm) } \\
\hline & & 314.09 & 333.97 & \begin{tabular}{|l|}
356.33 \\
\end{tabular} & 378.87 & 403.87 & 425.89 & 446.94 & 459.59 & 486.75 \\
\hline Constituent & Target & $\begin{array}{c}\text { JBL-G- } \\
109 \mathrm{~B}\end{array}$ & $\begin{array}{c}\text { JBL-G- } \\
113 \mathrm{~B}\end{array}$ & $\begin{array}{c}\text { JBL-G- } \\
114 \mathrm{~A}\end{array}$ & $\begin{array}{c}\text { JBL-G- } \\
114 \mathrm{C}\end{array}$ & $\begin{array}{c}\text { JBL-G- } \\
131 \mathrm{~A}\end{array}$ & $\begin{array}{c}\text { JBL-G- } \\
131 \mathrm{C}\end{array}$ & $\begin{array}{c}\text { JBL-G- } \\
136 \mathrm{~A}\end{array}$ & $\begin{array}{c}\mathrm{BBL}-\mathrm{G}- \\
136 \mathrm{C}\end{array}$ & $\begin{array}{c}\text { JBL-G- } \\
137 \mathrm{~B}\end{array}$ \\
\hline $\mathrm{Al}_{2} \mathrm{O}_{3}$ & 5.58 & 6.32 & 6.23 & 6.09 & 6.17 & 6.36 & 6.35 & 6.26 & 6.30 & 6.17 \\
\hline $\mathrm{B}_{2} \mathrm{O}_{3}$ & 13.81 & 14.03 & 14.20 & 14.38 & $14.56^{\#}$ & 14.48 & $14.41 \#$ & 14.45 & 14.47 & 14.52 \\
\hline $\mathrm{BaO}$ & 0.08 & 0.11 & 0.13 & 0.12 & 0.11 & 0.09 & 0.11 & 0.12 & 0.14 & 0.12 \\
\hline $\mathrm{Bi}_{2} \mathrm{O}_{3}$ & $\S$ & 0.04 & 0.03 & 0.04 & 0.03 & 0.05 & 0.03 & 0.04 & 0.04 & 0.03 \\
\hline $\mathrm{CaO}$ & 0.52 & 0.63 & 0.66 & 0.66 & 0.62 & 0.63 & 0.67 & 0.67 & 0.64 & 0.66 \\
\hline $\mathrm{CdO}$ & $\S$ & 0.06 & 0.05 & 0.05 & 0.05 & 0.06 & 0.06 & 0.05 & 0.06 & 0.05 \\
\hline $\mathrm{Ce}_{2} \mathrm{O}_{3}$ & 0.11 & 0.07 & 0.11 & 0.10 & 0.10 & 0.09 & 0.09 & 0.10 & 0.12 & 0.07 \\
\hline $\mathrm{Cr}_{2} \mathrm{O}_{3}$ & 0.25 & 0.26 & 0.26 & 0.23 & 0.23 & 0.25 & 0.23 & 0.23 & 0.25 & 0.23 \\
\hline $\mathrm{Cs}_{2} \mathrm{O}$ & $\S$ & $<0.01$ & $<0.01$ & $<0.01$ & $<0.01$ & $<0.01$ & $<0.01$ & $<0.01$ & $<0.01$ & $<0.01$ \\
\hline $\mathrm{Fe}_{2} \mathrm{O}_{3}$ & 16.01 & 16.54 & 16.58 & 17.04 & 16.92 & 16.71 & 16.82 & 16.80 & 16.54 & 17.36 \\
\hline $\mathrm{K}_{2} \mathrm{O}$ & $\S$ & 0.39 & 0.34 & 0.39 & 0.36 & 0.34 & 0.35 & 0.36 & 0.30 & 0.28 \\
\hline $\mathrm{La}_{2} \mathrm{O}_{3}$ & 0.09 & 0.06 & 0.08 & 0.08 & 0.10 & 0.08 & 0.12 & 0.07 & 0.09 & 0.07 \\
\hline $\mathrm{Li}_{2} \mathrm{O}$ & 1.55 & 1.50 & 1.48 & 1.47 & $1.45^{\#}$ & 1.49 & $1.52^{\#}$ & 1.51 & 1.50 & 1.49 \\
\hline $\mathrm{MgO}$ & 0.17 & 0.33 & 0.32 & 0.33 & 0.29 & 0.31 & 0.32 & 0.30 & 0.33 & 0.30 \\
\hline $\mathrm{MnO}$ & 3.22 & 2.65 & 2.56 & 2.54 & 2.58 & 2.48 & 2.45 & 2.52 & 2.37 & 2.62 \\
\hline $\mathrm{Na}_{2} \mathrm{O}$ & 14.16 & 13.97 & 13.79 & 13.48 & 14.15 & 14.05 & 13.65 & 14.07 & 14.16 & 14.01 \\
\hline $\mathrm{Nd}_{2} \mathrm{O}_{3}$ & $\S$ & $<0.01$ & 0.02 & $<0.01$ & $<0.01$ & $<0.01$ & 0.02 & $<0.01$ & $<0.01$ & $<0.01$ \\
\hline $\mathrm{NiO}$ & 0.47 & 0.47 & 0.50 & 0.47 & 0.46 & 0.46 & 0.44 & 0.46 & 0.43 & 0.49 \\
\hline $\mathrm{P}_{2} \mathrm{O}_{5}$ & 0.64 & 0.61 & 0.60 & 0.63 & 0.61 & 0.62 & 0.66 & 0.60 & 0.66 & 0.66 \\
\hline $\mathrm{PbO}$ & 0.62 & 0.52 & 0.52 & 0.53 & 0.52 & 0.52 & 0.50 & 0.49 & 0.48 & 0.51 \\
\hline $\mathrm{SiO}_{2}$ & 41.06 & 39.46 & 39.53 & 39.35 & 38.82 & 39.00 & 39.28 & 38.98 & 39.20 & 38.33 \\
\hline $\mathrm{SnO}_{2}$ & 0.07 & 0.09 & 0.09 & 0.13 & 0.08 & 0.08 & 0.09 & 0.09 & 0.10 & 0.09 \\
\hline $\mathrm{SO}_{3}$ & 0.22 & 0.37 & 0.39 & 0.37 & 0.35 & 0.25 & 0.28 & 0.32 & 0.31 & 0.36 \\
\hline $\mathrm{SrO}$ & 0.20 & 0.16 & 0.17 & 0.17 & 0.17 & 0.17 & 0.17 & 0.17 & 0.16 & 0.19 \\
\hline $\mathrm{TiO}_{2}$ & $\S$ & 0.09 & 0.08 & 0.08 & 0.08 & 0.10 & 0.08 & 0.09 & 0.08 & 0.08 \\
\hline $\mathrm{V}_{2} \mathrm{O}_{3}$ & $\S$ & 0.03 & 0.02 & 0.02 & $<0.01$ & 0.02 & 0.01 & 0.01 & 0.02 & 0.01 \\
\hline $\mathrm{ZnO}$ & 0.03 & 0.12 & 0.12 & 0.13 & 0.12 & 0.16 & 0.15 & 0.13 & 0.15 & 0.14 \\
\hline $\mathrm{ZrO}_{2}$ & 1.12 & 1.11 & 1.12 & 1.12 & 1.09 & 1.15 & 1.13 & 1.12 & 1.11 & 1.16 \\
\hline Sum & 100.00 & 100.00 & 100.00 & 100.00 & 100.00 & 100.00 & 100.00 & 100.00 & 100.00 & 100.00 \\
\hline
\end{tabular}

$\S$ - Not a target constituent

\# - $\mathrm{B}_{2} \mathrm{O}_{3}$ and $\mathrm{Li}_{2} \mathrm{O}$ were measured by DCP-AES, values for other samples calculated by interpolation 
Table 4.5. XRF Analyzed Composition for Glass Discharged During DM100 Melter Tests (wt\%) (continued).

\begin{tabular}{|c|c|c|c|c|c|c|c|c|c|c|}
\hline \multirow{2}{*}{\multicolumn{2}{|c|}{$\begin{array}{c}\text { Test } \\
\text { Glass }(\mathrm{kg})\end{array}$}} & \multicolumn{9}{|c|}{ Fixed Bubbling (9 lpm) } \\
\hline & & 507.77 & 523.53 & 548.63 & 577.33 & 605.73 & 631.63 & 651.93 & 672.61 & 695.15 \\
\hline Constituent & Target & $\begin{array}{c}\text { JBL-G- } \\
138 \mathrm{~A}\end{array}$ & $\begin{array}{c}\text { JBL-G- } \\
138 \mathrm{C}\end{array}$ & $\begin{array}{c}\text { JBL-G- } \\
142 B \\
\end{array}$ & $\begin{array}{c}\text { JBL-G- } \\
143 \mathrm{~A}\end{array}$ & $\begin{array}{c}\text { JBL-G- } \\
143 \mathrm{C}\end{array}$ & $\begin{array}{c}\text { JBL-G- } \\
148 \mathrm{~A}\end{array}$ & $\begin{array}{c}\text { JBL-G- } \\
150 \mathrm{~A}\end{array}$ & $\begin{array}{c}\text { JBL-G- } \\
150 \mathrm{C}\end{array}$ & $\begin{array}{r}\text { JBL-G } \\
151 \mathrm{~A}\end{array}$ \\
\hline $\mathrm{Al}_{2} \mathrm{O}_{3}$ & 5.58 & 6.14 & 6.15 & 6.14 & 6.07 & 6.04 & 6.00 & 5.99 & 5.93 & 6.03 \\
\hline $\mathrm{B}_{2} \mathrm{O}_{3}$ & 13.81 & 14.55 & $14.58^{\#}$ & 14.54 & 14.49 & 14.44 & $14.40^{\#}$ & 14.41 & 14.42 & 14.43 \\
\hline $\mathrm{BaO}$ & 0.08 & 0.10 & 0.11 & 0.12 & 0.10 & 0.11 & 0.12 & 0.12 & 0.11 & 0.11 \\
\hline $\mathrm{Bi}_{2} \mathrm{O}_{3}$ & $\S$ & 0.03 & 0.03 & 0.03 & 0.02 & 0.02 & 0.02 & 0.02 & 0.01 & 0.02 \\
\hline $\mathrm{CaO}$ & 0.52 & 0.63 & 0.62 & 0.59 & 0.62 & 0.61 & 0.63 & 0.65 & 0.60 & 0.60 \\
\hline $\mathrm{CdO}$ & $\S$ & 0.05 & 0.04 & 0.05 & 0.04 & 0.04 & 0.04 & 0.04 & 0.04 & 0.03 \\
\hline $\mathrm{Ce}_{2} \mathrm{O}_{3}$ & 0.11 & 0.08 & 0.13 & 0.10 & 0.08 & 0.13 & 0.08 & 0.12 & 0.10 & 0.08 \\
\hline $\mathrm{Cr}_{2} \mathrm{O}_{3}$ & 0.25 & 0.26 & 0.26 & 0.24 & 0.25 & 0.27 & 0.26 & 0.25 & 0.24 & 0.24 \\
\hline $\mathrm{Cs}_{2} \mathrm{O}$ & $\S$ & $<0.01$ & $<0.01$ & $<0.01$ & $<0.01$ & $<0.01$ & $<0.01$ & $<0.01$ & $<0.01$ & $<0.01$ \\
\hline $\mathrm{Fe}_{2} \mathrm{O}_{3}$ & 16.01 & 17.39 & 17.48 & 17.43 & 17.50 & 17.73 & 17.72 & 17.68 & 17.31 & 16.93 \\
\hline $\mathrm{K}_{2} \mathrm{O}$ & $\S$ & 0.36 & 0.29 & 0.33 & 0.28 & 0.32 & 0.36 & 0.31 & 0.31 & 0.29 \\
\hline $\mathrm{La}_{2} \mathrm{O}_{3}$ & 0.09 & 0.09 & 0.07 & 0.09 & 0.08 & 0.06 & 0.11 & 0.07 & 0.09 & 0.08 \\
\hline $\mathrm{Li}_{2} \mathrm{O}$ & 1.55 & 1.48 & $1.47^{\#}$ & 1.46 & 1.45 & 1.43 & $1.42^{\#}$ & 1.42 & 1.43 & 1.43 \\
\hline $\mathrm{MgO}$ & 0.17 & 0.31 & 0.32 & 0.31 & 0.31 & 0.32 & 0.29 & 0.32 & 0.33 & 0.29 \\
\hline $\mathrm{MnO}$ & 3.22 & 2.53 & 2.52 & 2.54 & 2.54 & 2.54 & 2.53 & 2.57 & 2.48 & 2.45 \\
\hline $\mathrm{Na}_{2} \mathrm{O}$ & 14.16 & 14.06 & 14.14 & 13.79 & 13.82 & 13.36 & 13.29 & 13.59 & 14.35 & 14.31 \\
\hline $\mathrm{Nd}_{2} \mathrm{O}_{3}$ & $\S$ & $<0.01$ & $<0.01$ & $<0.01$ & $<0.01$ & $<0.01$ & $<0.01$ & $<0.01$ & $<0.01$ & $<0.01$ \\
\hline $\mathrm{NiO}$ & 0.47 & 0.49 & 0.47 & 0.49 & 0.47 & 0.51 & 0.46 & 0.48 & 0.46 & 0.47 \\
\hline $\mathrm{P}_{2} \mathrm{O}_{5}$ & 0.64 & 0.64 & 0.63 & 0.63 & 0.63 & 0.63 & 0.63 & 0.63 & 0.64 & 0.63 \\
\hline $\mathrm{PbO}$ & 0.62 & 0.53 & 0.53 & 0.49 & 0.52 & 0.52 & 0.52 & 0.51 & 0.48 & 0.47 \\
\hline $\mathrm{SiO}_{2}$ & 41.06 & 38.31 & 38.21 & 38.73 & 38.85 & 38.95 & 39.15 & 38.88 & 38.81 & 39.28 \\
\hline $\mathrm{SnO}_{2}$ & 0.07 & 0.09 & 0.09 & 0.10 & 0.08 & 0.09 & 0.09 & 0.09 & 0.09 & 0.08 \\
\hline $\mathrm{SO}_{3}$ & 0.22 & 0.34 & 0.34 & 0.35 & 0.34 & 0.37 & 0.34 & 0.39 & 0.36 & 0.39 \\
\hline $\mathrm{SrO}$ & 0.20 & 0.18 & 0.17 & 0.17 & 0.18 & 0.18 & 0.18 & 0.17 & 0.17 & 0.16 \\
\hline $\mathrm{TiO}_{2}$ & $\S$ & 0.09 & 0.09 & 0.08 & 0.09 & 0.09 & 0.10 & 0.08 & 0.08 & 0.09 \\
\hline $\mathrm{V}_{2} \mathrm{O}_{3}$ & $\S$ & 0.02 & 0.02 & $<0.01$ & $<0.01$ & $<0.01$ & $<0.01$ & $<0.01$ & $<0.01$ & $<0.01$ \\
\hline $\mathrm{ZnO}$ & 0.03 & 0.12 & 0.12 & 0.11 & 0.11 & 0.11 & 0.11 & 0.11 & 0.10 & 0.09 \\
\hline $\mathrm{ZrO}_{2}$ & 1.12 & 1.14 & 1.13 & 1.11 & 1.10 & 1.11 & 1.12 & 1.11 & 1.07 & 1.04 \\
\hline Sum & 100.00 & 100.00 & 100.00 & 100.00 & 100.00 & 100.00 & 100.00 & 100.00 & 100.00 & 100.00 \\
\hline
\end{tabular}

$\S$ - Not a target constituent

\# - $\mathrm{B}_{2} \mathrm{O}_{3}$ and $\mathrm{Li}_{2} \mathrm{O}$ were measured by DCP-AES, values for other samples calculated by interpolation 
Table 4.5. XRF Analyzed Composition for Glass Discharged During DM100 Melter Tests (wt\%) (continued).

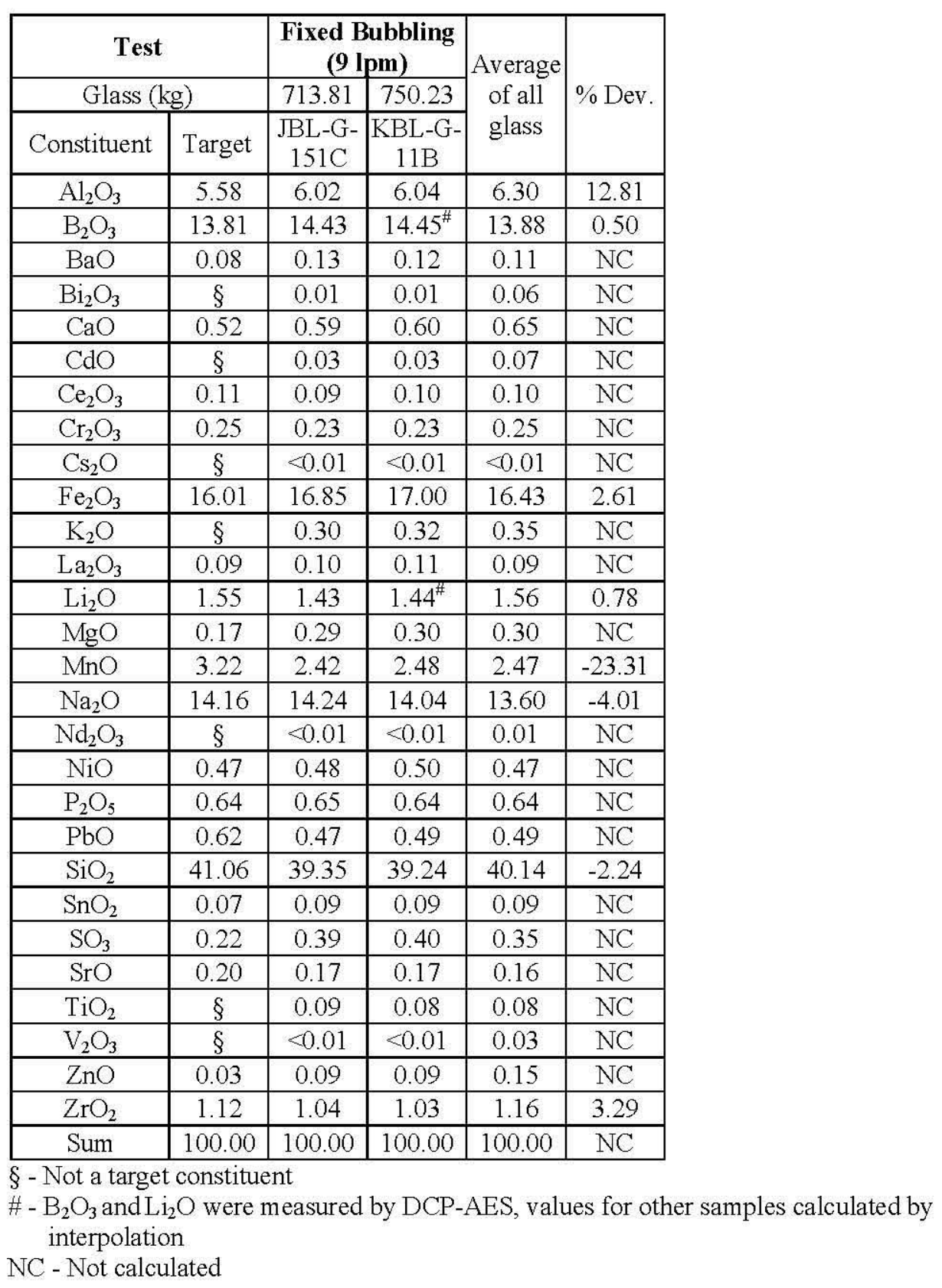


Table 4.6. XRF Analyzed Composition for Dip Samples Taken Before and After DM100 Melter Tests (wt\%).

\begin{tabular}{|c|c|c|c|c|c|}
\hline \multirow{2}{*}{ Test } & \multicolumn{3}{|c|}{ Optimized Bubbling } & \multicolumn{2}{|c|}{$\begin{array}{c}\text { Fixed Bubbling } \\
(9 \mathrm{lpm})\end{array}$} \\
\hline & \multirow{2}{*}{ Target } & Before & After & Before & After \\
\hline Constituent & & JBL-D-79A & JBL-D-114A & JBL-D-120A & KBL-D-11A \\
\hline $\mathrm{Al}_{2} \mathrm{O}_{3}$ & 5.58 & 7.16 & 6.00 & 6.54 & 5.98 \\
\hline $\mathrm{B}_{2} \mathrm{O}_{3}$ & 13.81 & $11.80^{*}$ & $14.56^{*}$ & $14.48 *$ & $14.45^{*}$ \\
\hline $\mathrm{BaO}$ & 0.08 & 0.08 & 0.11 & 0.12 & 0.14 \\
\hline $\mathrm{Bi}_{2} \mathrm{O}_{3}$ & $\S$ & 0.23 & 0.03 & 0.04 & 0.01 \\
\hline $\mathrm{CaO}$ & 0.52 & 0.81 & 0.66 & 0.63 & 0.57 \\
\hline $\mathrm{CdO}$ & $\S$ & 0.23 & 0.06 & 0.07 & 0.03 \\
\hline $\mathrm{Ce}_{2} \mathrm{O}_{3}$ & 0.11 & 0.13 & 0.11 & 0.11 & 0.14 \\
\hline $\mathrm{Cr}_{2} \mathrm{O}_{3}$ & 0.25 & 0.29 & 0.23 & 0.17 & 0.23 \\
\hline $\mathrm{Cs}_{2} \mathrm{O}$ & $\S$ & 0.03 & $<0.01$ & $<0.01$ & $<0.01$ \\
\hline $\mathrm{Fe}_{2} \mathrm{O}_{3}$ & 16.01 & 13.57 & 17.28 & 15.51 & 17.31 \\
\hline $\mathrm{K}_{2} \mathrm{O}$ & $\S$ & 0.45 & 0.37 & 0.39 & 0.32 \\
\hline $\mathrm{La}_{2} \mathrm{O}_{3}$ & 0.09 & 0.12 & 0.08 & 0.09 & 0.09 \\
\hline $\mathrm{Li}_{2} \mathrm{O}$ & 1.55 & $2.18^{*}$ & $1.45^{*}$ & $1.49 *$ & $1.44 *$ \\
\hline $\mathrm{MgO}$ & 0.17 & 0.28 & 0.31 & 0.31 & 0.31 \\
\hline $\mathrm{MnO}$ & 3.22 & 1.99 & 2.59 & 2.30 & 2.44 \\
\hline $\mathrm{Na}_{2} \mathrm{O}$ & 14.16 & 12.90 & 13.57 & 14.39 & 13.98 \\
\hline $\mathrm{Nd}_{2} \mathrm{O}_{3}$ & $\S$ & 0.10 & $<0.01$ & $<0.01$ & 0.02 \\
\hline $\mathrm{NiO}$ & 0.47 & 0.46 & 0.49 & 0.31 & 0.50 \\
\hline $\mathrm{P}_{2} \mathrm{O}_{5}$ & 0.64 & 0.69 & 0.62 & 0.64 & 0.63 \\
\hline $\mathrm{PbO}$ & 0.62 & 0.39 & 0.51 & 0.46 & 0.48 \\
\hline $\mathrm{SiO}_{2}$ & 41.06 & 43.44 & 38.97 & 40.12 & 39.08 \\
\hline $\mathrm{SnO}_{2}$ & 0.07 & 0.12 & 0.09 & 0.09 & 0.08 \\
\hline $\mathrm{SO}_{3}$ & 0.22 & 0.38 & 0.39 & 0.23 & 0.39 \\
\hline $\mathrm{SrO}$ & 0.20 & 0.12 & 0.17 & 0.16 & 0.17 \\
\hline $\mathrm{TiO}_{2}$ & $\S$ & 0.07 & 0.08 & 0.09 & 0.08 \\
\hline $\mathrm{V}_{2} \mathrm{O}_{3}$ & $\S$ & 0.12 & 0.01 & 0.02 & 0.00 \\
\hline $\mathrm{ZnO}$ & 0.03 & 0.32 & 0.12 & 0.15 & 0.09 \\
\hline $\mathrm{ZrO}_{2}$ & 1.12 & 1.54 & 1.12 & 1.09 & 1.04 \\
\hline Sum & 100.00 & 100.00 & 100.00 & 100.00 & 100.00 \\
\hline
\end{tabular}

$\S$ - Not a target constituent

* - Value from DCP-AES analysis of contemporaneous discharge glass. 
Table 4.7. Results from PCT (ASTM C1285, 7-days at $90^{\circ} \mathrm{C}$, Stainless Steel Vessel;

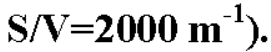

\begin{tabular}{|c|c|c|c|c|}
\hline \multicolumn{2}{|l|}{ Test } & $\begin{array}{c}\text { Optimized } \\
\text { Bubbling }\end{array}$ & $\begin{array}{c}\text { Fixed Bubbling } \\
(9 \mathrm{lpm})\end{array}$ & \multirow[t]{2}{*}{ DWPF-EA } \\
\hline \multicolumn{2}{|c|}{ Glass Samples } & JBL-G-114C & KBL-G-11B & \\
\hline \multirow{4}{*}{$\begin{array}{c}\text { PCT } \\
\text { Concentration in } \\
\mathrm{mg} / \mathrm{L}\end{array}$} & $\mathrm{B}$ & 61.41 & 69.65 & \\
\hline & $\mathrm{Li}$ & 7.18 & 7.77 & \\
\hline & $\mathrm{Na}$ & 96.65 & 104.83 & \\
\hline & $\mathrm{Si}$ & 51.35 & 53.01 & \\
\hline \multirow{5}{*}{$\begin{array}{c}\text { PCT Normalized } \\
\text { Concentrations, } \\
\text { g/L }\end{array}$} & $\mathrm{B}$ & 1.43 & 1.62 & 16.695 \\
\hline & $\mathrm{Li}$ & 1.00 & 1.08 & 9.565 \\
\hline & $\mathrm{Na}$ & 0.92 & 1.00 & 13.346 \\
\hline & $\mathrm{Si}$ & 0.27 & 0.28 & 3.922 \\
\hline & $\mathrm{pH}$ & 9.77 & 9.75 & 11.85 \\
\hline \multirow{4}{*}{$\begin{array}{l}\text { PCT Normalized } \\
\text { Mass Loss }\left(\mathrm{g} / \mathrm{m}^{2}\right)\end{array}$} & $\mathrm{B}$ & 0.72 & 0.81 & \\
\hline & $\mathrm{Li}$ & 0.50 & 0.54 & \\
\hline & $\mathrm{Na}$ & 0.46 & 0.50 & \\
\hline & $\mathrm{Si}$ & 0.13 & 0.14 & \\
\hline \multirow{4}{*}{$\begin{array}{l}\text { PCT Normalized } \\
\text { Loss Rate, } \mathrm{g} / \mathrm{d} / \mathrm{m}^{2}\end{array}$} & $\mathrm{~B}$ & 0.10 & 0.12 & \\
\hline & $\mathrm{Li}$ & 0.07 & 0.08 & \\
\hline & $\mathrm{Na}$ & 0.07 & 0.07 & \\
\hline & $\mathrm{Si}$ & 0.02 & 0.02 & \\
\hline
\end{tabular}


Table 4.8. TCLP Results for Discharged Glass Samples (mg/L).

\begin{tabular}{|c|c|c|c|c|c|c|c|}
\hline \multirow{3}{*}{ Test } & Element & $\mathbf{B a}$ & $\mathbf{C d}$ & $\mathbf{C r}$ & $\mathbf{N i}$ & $\mathbf{P b}$ & $\mathbf{Z n}$ \\
\cline { 2 - 8 } & UTS Limits & 21 & 0.11 & 0.60 & 11.00 & 0.75 & 4.3 \\
\cline { 2 - 8 } & Delisting Limits & 100 & 0.480 & 4.95 & 22.6 & 5.00 & 225 \\
\hline $\begin{array}{c}\text { Optimized } \\
\text { Bubbling }\end{array}$ & JBL-G-114C & 0.78 & $<0.03$ & $<0.01$ & 0.06 & $<0.10$ & 0.41 \\
\hline $\begin{array}{c}\text { Fixed Bubbling } \\
(9 \mathrm{lpm})\end{array}$ & KBL-G-11B & 0.58 & $<0.03$ & $<0.01$ & 0.05 & $<0.10$ & 0.23 \\
\hline
\end{tabular}

\# For comparison only; does not apply to WTP glasses 
Table 4.9. Results of SEM Analysis of Discharged Glasses.

\begin{tabular}{|c|c|c|}
\hline Sample & Crystal Content & Crystal Morphology \\
\hline $\begin{array}{c}\text { JBL-G-114C from } \\
\text { end of test with } \\
\text { optimized } \\
\text { bubbling }\end{array}$ & $\begin{array}{c}\text { 0.1 volume percent Cr-Ni- } \\
\text { Mn-Fe spinels }\end{array}$ & $\begin{array}{c}\text { Euhedral equant grains 5-10 micron in size. The spinel } \\
\text { is unevenly distributed in the glass and is not clustered } \\
\text { (Figure 4.3). }\end{array}$ \\
\hline $\begin{array}{c}\text { KBL-G-11B from } \\
\text { end of test with } \\
\text { fixed bubbling }\end{array}$ & $\begin{array}{c}\text { Mn-Fe-spinel with small } \\
\text { amounts of Cr and Zn }\end{array}$ & $\begin{array}{c}\text { Spinel, the only crystal phase found in the glass, is } \\
\text { present in a bi-modal size distribution. The large } \\
\text { crystals are euhedral equant grain, mainly 5-10 micron } \\
\text { size, about 0.15\% of sample area (Figure 4.4.a). The } \\
\text { small spinel is 0.2-1 micron size, clustered along in a } \\
\text { string pattern, sub-euhedral equant grain, and is about } \\
0.95 \% \text { of sample area (Figure 4.4.b). }\end{array}$ \\
\hline
\end{tabular}


Table 5.1. Results from DM100 Off-Gas Emission Samples.

\begin{tabular}{|c|c|c|c|c|c|c|c|c|c|}
\hline & \multicolumn{4}{|c|}{$\begin{array}{c}\text { 12/9/2011 15:43 - 16:43 } \\
17.1 \% \text { Moisture, } 113 \% \text { Isokinetic }\end{array}$} & \multicolumn{4}{|c|}{$\begin{array}{c}1 / 4 / 201219: 37-20: 37 \\
15.0 \% \text { Moisture, } 113 \% \text { Isokinetic }\end{array}$} \\
\hline & & $\begin{array}{c}\text { Feed }^{\#} \\
(\mathrm{mg} / \mathrm{min})\end{array}$ & $\begin{array}{l}\text { Emissions Flux } \\
(\mathrm{mg} / \mathrm{min})\end{array}$ & $\%$ Emitted & $\mathrm{DF}$ & $\begin{array}{c}\text { Feed }^{\#} \\
(\mathrm{mg} / \mathrm{min})\end{array}$ & $\begin{array}{c}\text { Emissions } \\
\text { Flux }(\mathrm{mg} / \mathrm{min})\end{array}$ & $\%$ Emitted & $\mathrm{DF}$ \\
\hline \multirow{20}{*}{ 茑 } & Total $^{\$}$ & 164248 & 1166 & 0.71 & 141 & 140282 & 923 & 0.66 & 152 \\
\hline & $\mathrm{Al}$ & 4208 & 21.5 & 0.51 & 196 & 3654 & 14.84 & 0.41 & 246 \\
\hline & B & 6109 & 96.6 & 1.58 & 63.3 & 5305 & 75.95 & 1.43 & 69.9 \\
\hline & $\mathrm{Ba}$ & 102 & 0.93 & 0.91 & 110 & 89 & 0.65 & 0.73 & 137 \\
\hline & $\mathrm{Ca}$ & 530 & 6.11 & 1.15 & 86.8 & 460 & 4.02 & 0.87 & 115 \\
\hline & $\mathrm{Cr}$ & 244 & 4.25 & 1.74 & 57.4 & 212 & 4.19 & 1.98 & 50.5 \\
\hline & $\mathrm{Fe}$ & 15958 & 122 & 0.76 & 131 & 13858 & 98.3 & 0.71 & 141 \\
\hline & $\mathrm{Li}$ & 1026 & 9.66 & 0.94 & 106 & 891 & 7.34 & 0.82 & 121 \\
\hline & $\mathrm{Mg}$ & 146 & 2.83 & 1.94 & 51.6 & 127 & 2.14 & 1.69 & 59.2 \\
\hline & $\mathrm{Mn}$ & 3555 & 1.25 & 0.04 & 2848 & 3087 & 0.72 & 0.02 & 4303 \\
\hline & $\mathrm{Na}$ & 14975 & 156 & 1.04 & 96.2 & 13005 & 131 & 1.01 & 99.0 \\
\hline & $\mathrm{Ni}$ & 527 & 1.39 & 0.26 & 380 & 457 & 0.95 & 0.21 & 480 \\
\hline & $\mathrm{P}$ & 398 & 1.38 & 0.35 & 288 & 346 & 1.19 & 0.35 & 290 \\
\hline & $\mathrm{Pb}$ & 820 & 6.59 & 0.80 & 124 & 712 & 5.28 & 0.74 & 135 \\
\hline & $S^{*}$ & 126 & 31.1 & 24.8 & 4.0 & 109 & 25.7 & 23.5 & 4.3 \\
\hline & $\mathrm{Sn}$ & 79 & 0.60 & 0.76 & 132 & 68 & 0.61 & 0.89 & 113 \\
\hline & $\mathrm{Si}$ & 27353 & 96.6 & 0.35 & 283 & 23754 & 73.5 & 0.31 & 323 \\
\hline & $\mathrm{Sr}$ & 241 & 2.33 & 0.96 & 104 & 209 & 1.49 & 0.71 & 141 \\
\hline & $\mathrm{Zn}$ & 34 & 0.83 & 2.41 & 41.4 & 30 & 0.49 & 1.65 & 60.6 \\
\hline & $\mathrm{Zr}$ & 1182 & 2.12 & 0.18 & 558 & 1026 & 1.10 & 0.11 & 932 \\
\hline \multirow{2}{*}{$\tilde{\Xi}^{\tilde{Z}}$} & $\mathrm{~B}$ & 6109 & 42.9 & 0.70 & 142 & 5305 & 44.5 & 0.84 & 119 \\
\hline & $S$ & 126 & 66.2 & 52.7 & 1.9 & 109 & 65.7 & 60.2 & 1.7 \\
\hline
\end{tabular}


Table 5.2. Concentrations (ppmv) of Selected Species in DM100 Exhaust Measured by FTIR Spectroscopy.

\begin{tabular}{|c|c|c|}
\hline \multirow{2}{*}{ Test } & \multicolumn{2}{|c|}{ Fixed Bubbling (9 lpm) } \\
\cline { 2 - 3 } & Avg. & Range \\
\hline $\mathrm{N}_{2} \mathrm{O}$ & $<1.0$ & $<1.0-1.7$ \\
\hline $\mathrm{NO}$ & 38.6 & $<1.0-104$ \\
\hline $\mathrm{NO}_{2}$ & $<1.0$ & $<1.0-2.5$ \\
\hline $\mathrm{NH}_{3}$ & $<1.0$ & $<1.0-7.5$ \\
\hline $\mathrm{H}_{2} \mathrm{O}[\%]$ & 8.2 & $3.0-25.3$ \\
\hline $\mathrm{CO}_{2}$ & 1423 & $374-3097$ \\
\hline $\mathrm{Nitrous} \mathrm{Acid}$ & $<1.0$ & $\mathrm{NA}$ \\
\hline $\mathrm{Nitric} \mathrm{Acid}$ & $<1.0$ & $\mathrm{NA}$ \\
\hline $\mathrm{HCN}$ & $<1.0$ & $\mathrm{NA}$ \\
\hline $\mathrm{CO}$ & 3.0 & $<1.0-6.5$ \\
\hline $\mathrm{HCl}$ & $<1.0$ & $\mathrm{NA}$ \\
\hline $\mathrm{HF}$ & 1.5 & $<1.0-2.6$ \\
\hline
\end{tabular}

NA : Not applicable. 


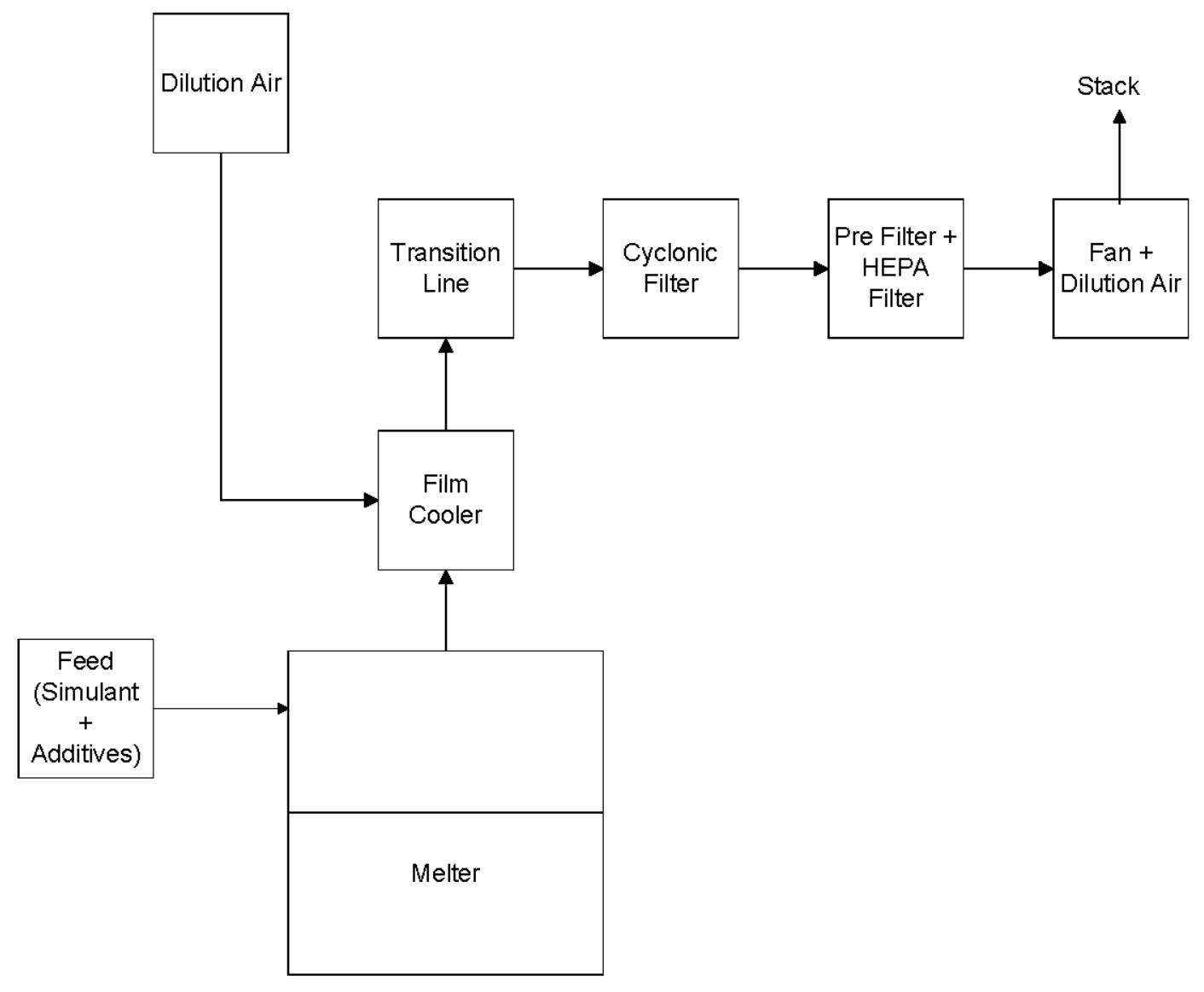

Figure 1.1. Schematic diagram of DuraMelter 100 vitrification system. 


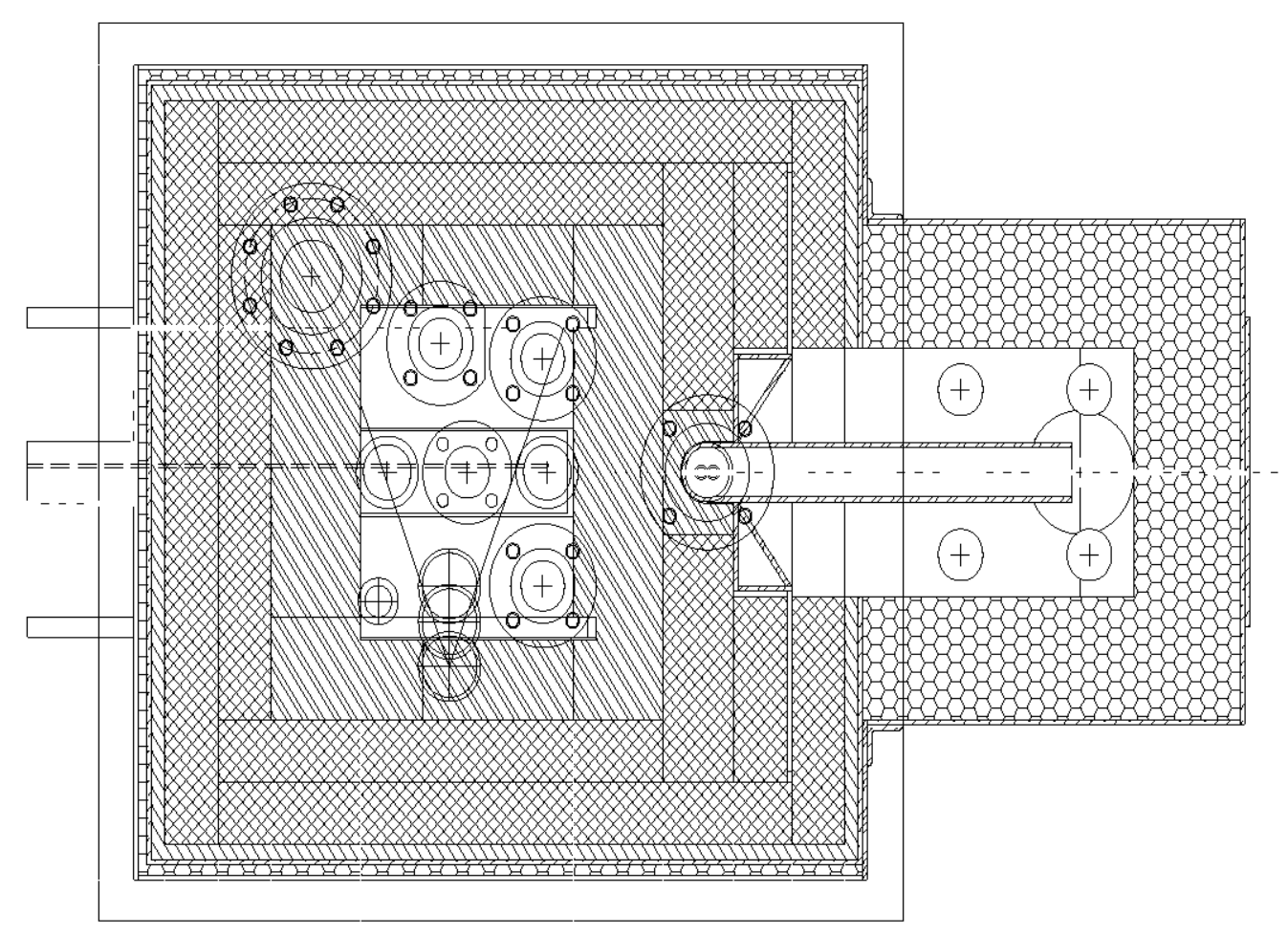

Figure 1.2.a. Schematic diagram showing cross-section through the DM100-BL-melter. Plan view showing locations of lid ports. 


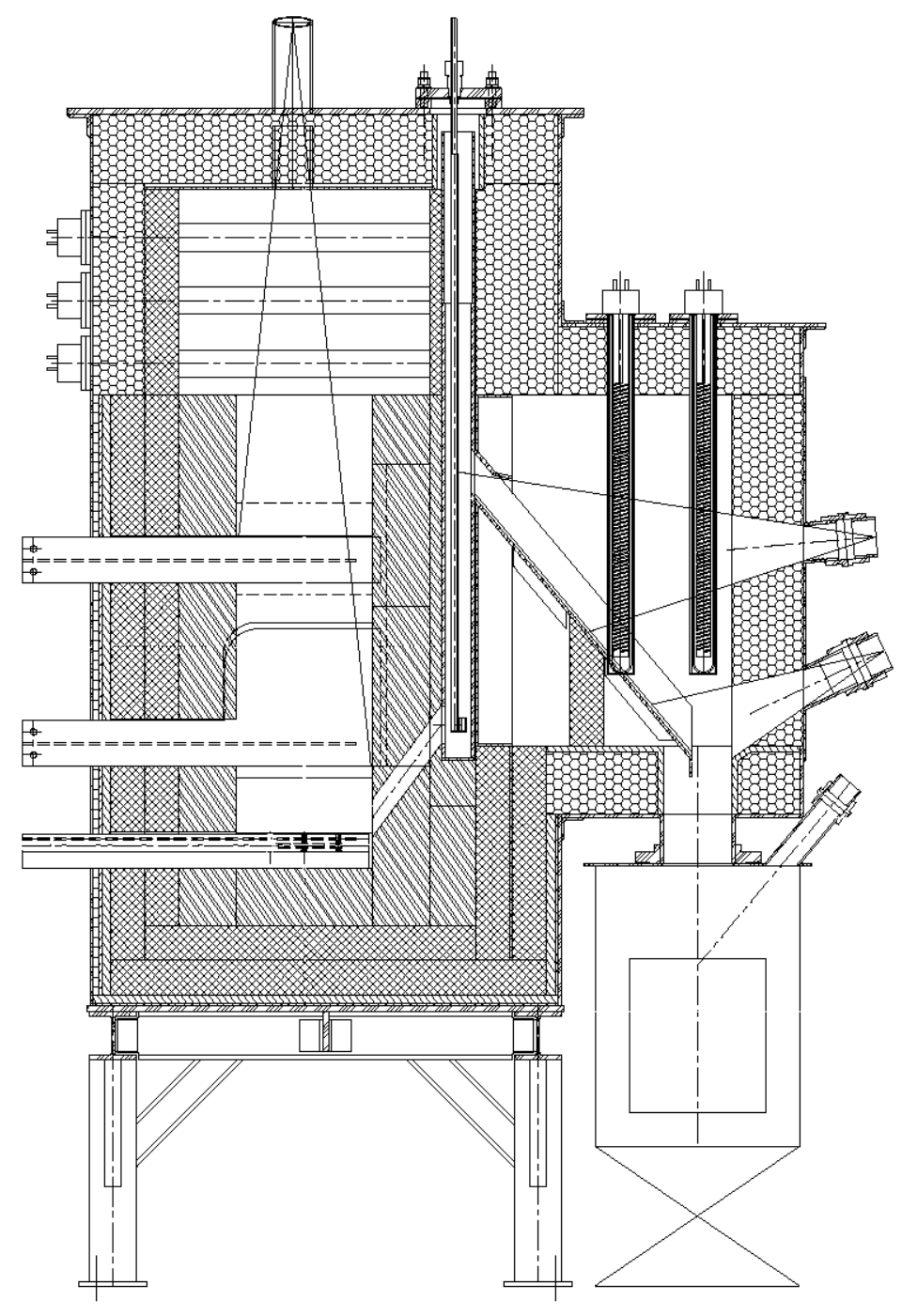

Figure 1.2.b. Schematic diagram showing cross-section through the DM100-BL melter. 


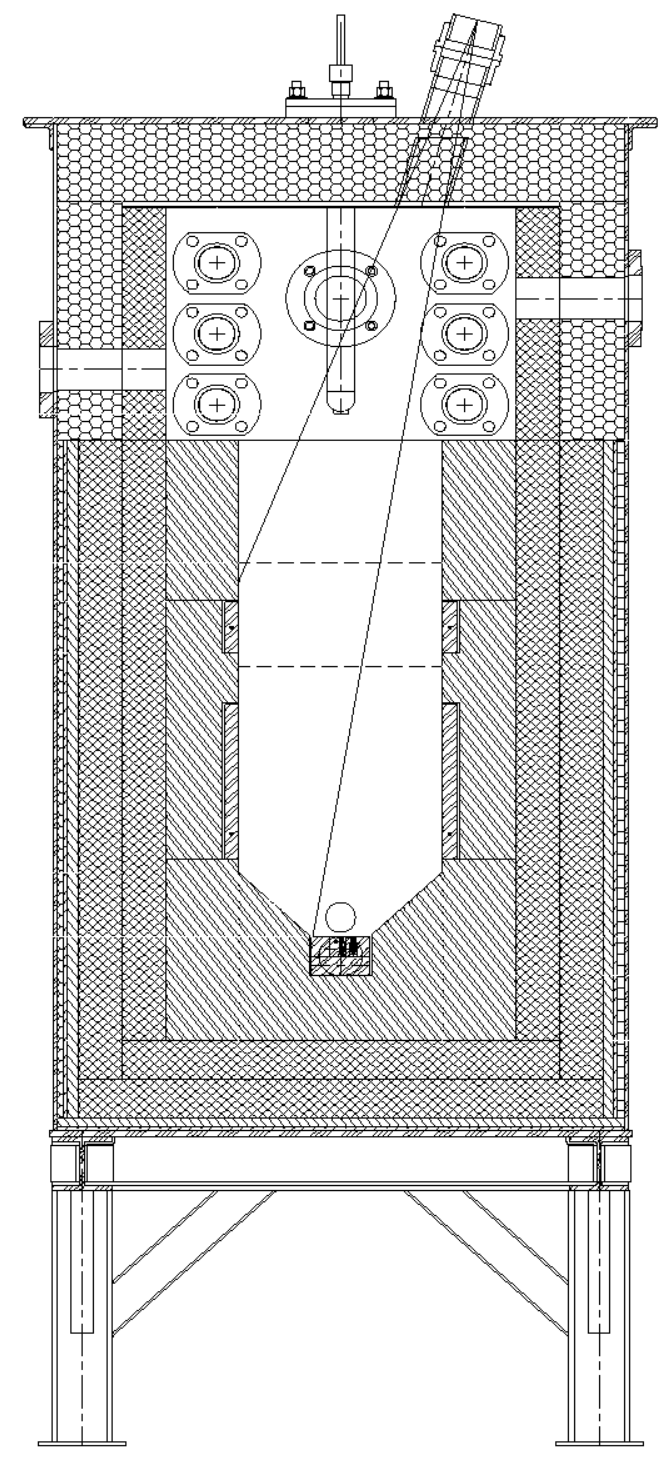

Figure 1.2.c. Schematic diagram showing cross-section through the DM100-BL melter. 


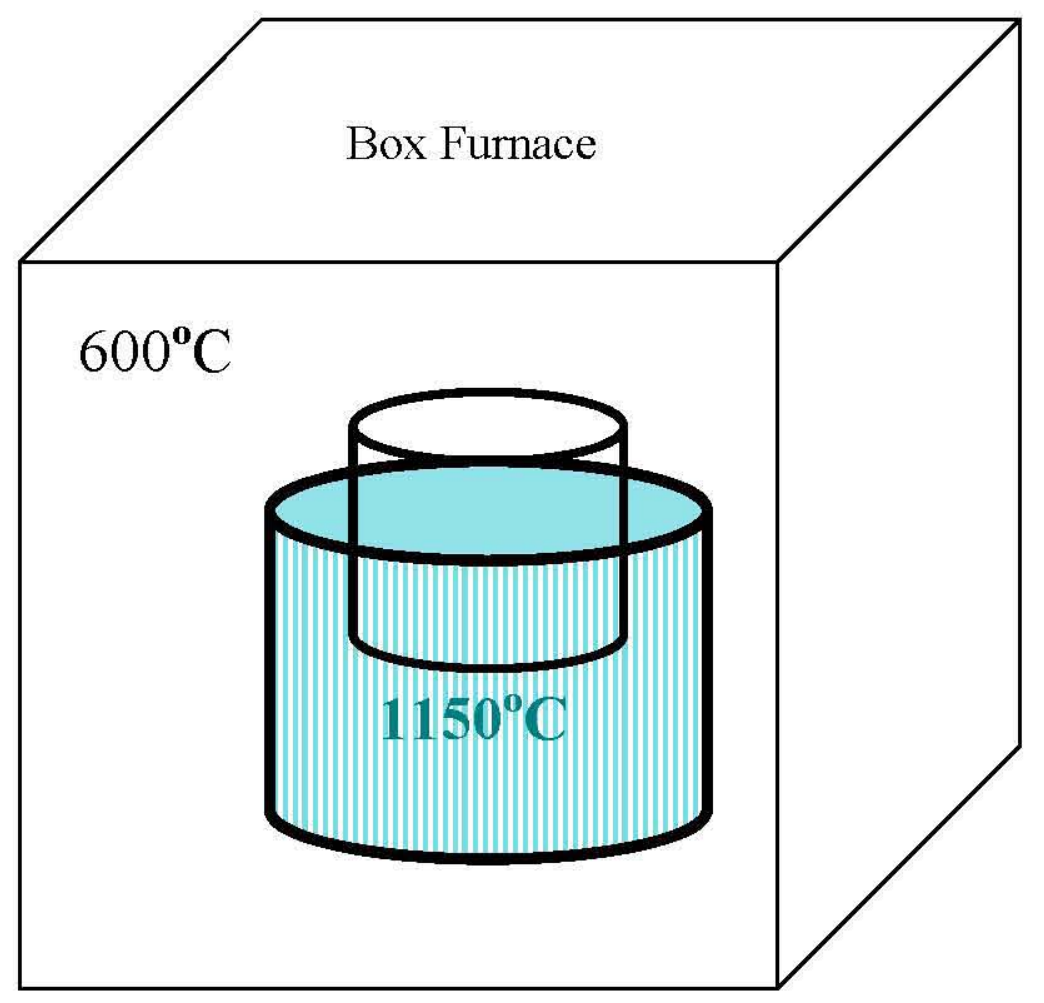

Figure 1.3. Schematic drawing of vertical gradient furnace (VGF) for feed conversion test 


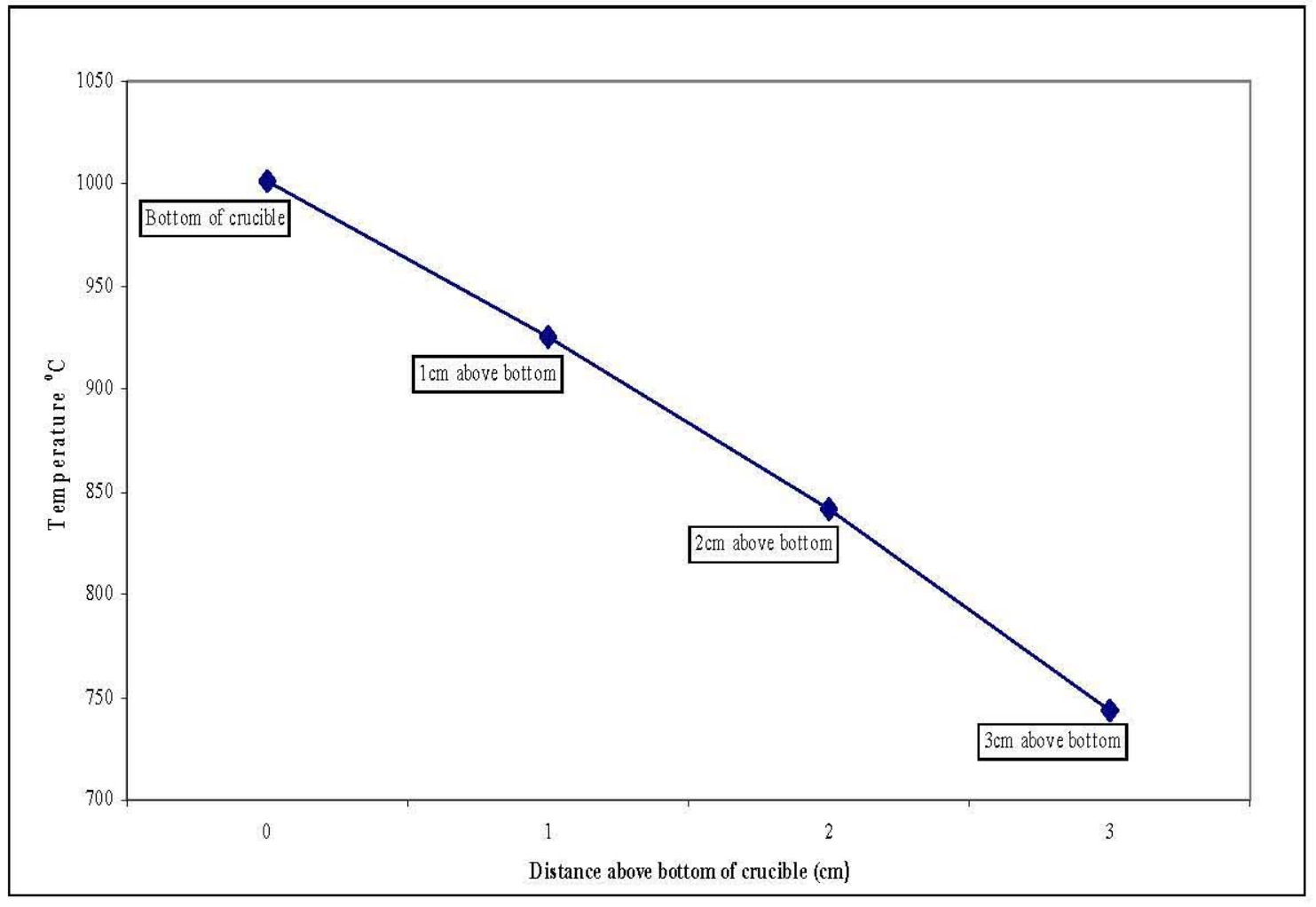

Figure 1.4. Temperature gradient (inside the loaded ceramic crucible) of the Vertical Gradient Furnace (VGF). 
a) HLW-NG-Fe0 (37.1 wt\% loading) $30 \mathrm{~min}$ b) HLW-NG-Fe1 (37.1 wt\% loading) $30 \mathrm{~min}$

$60 \mathrm{~min}$
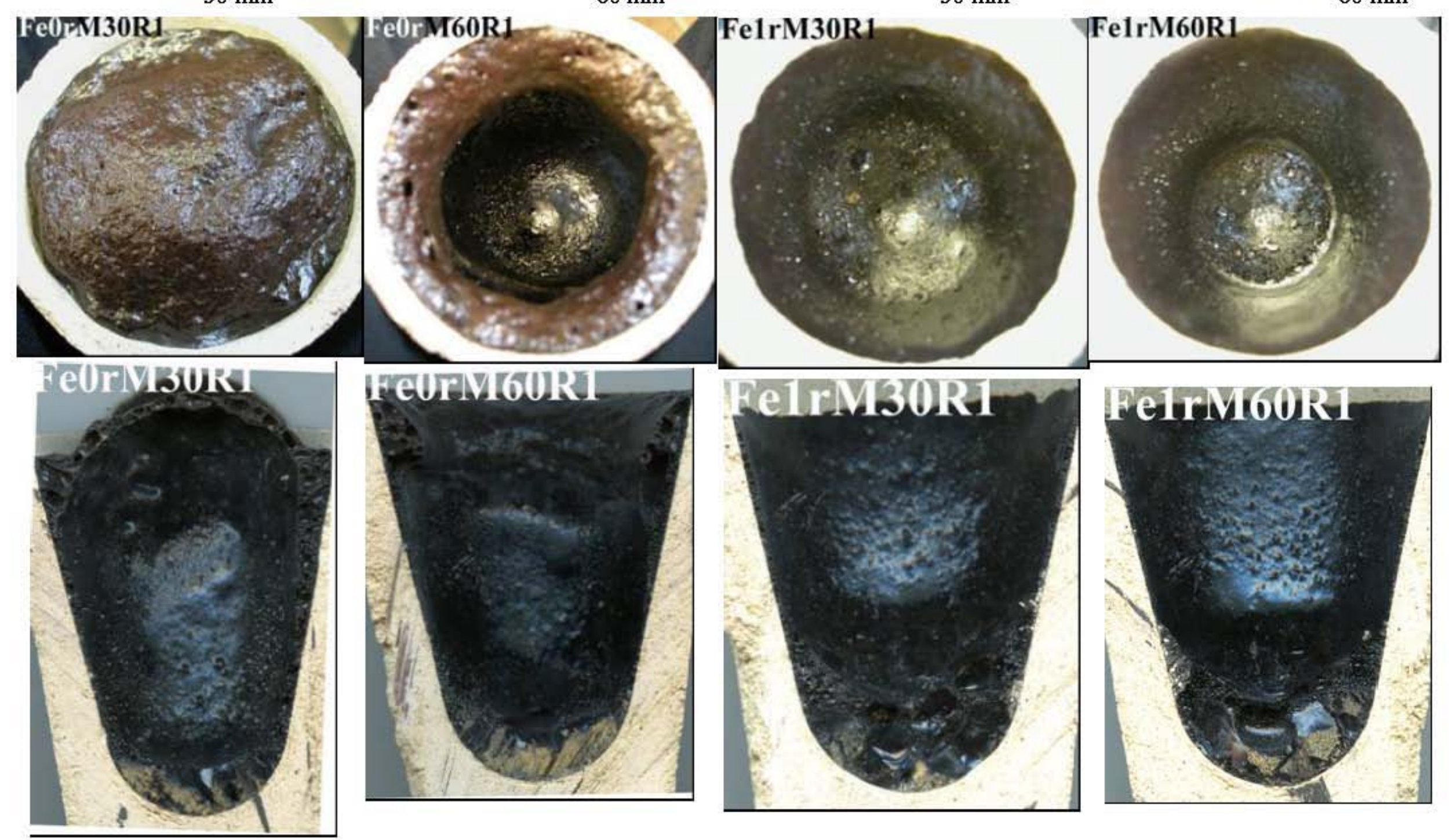

Figure 2.1. Top and cross section views of high iron feed samples after VGF experiments: a) HLW-NG-F $\mathrm{H}$ (non-radioactive version of HLW04-09); b) HLW-NG-Fe1. 
c) HLW-NG-Fe2 (42 wt\% loading) $30 \mathrm{~min}$
$60 \mathrm{~min}$ d) HLW-NG-Fe3 (47 wt\% loading) $30 \mathrm{~min}$

$60 \mathrm{~min}$
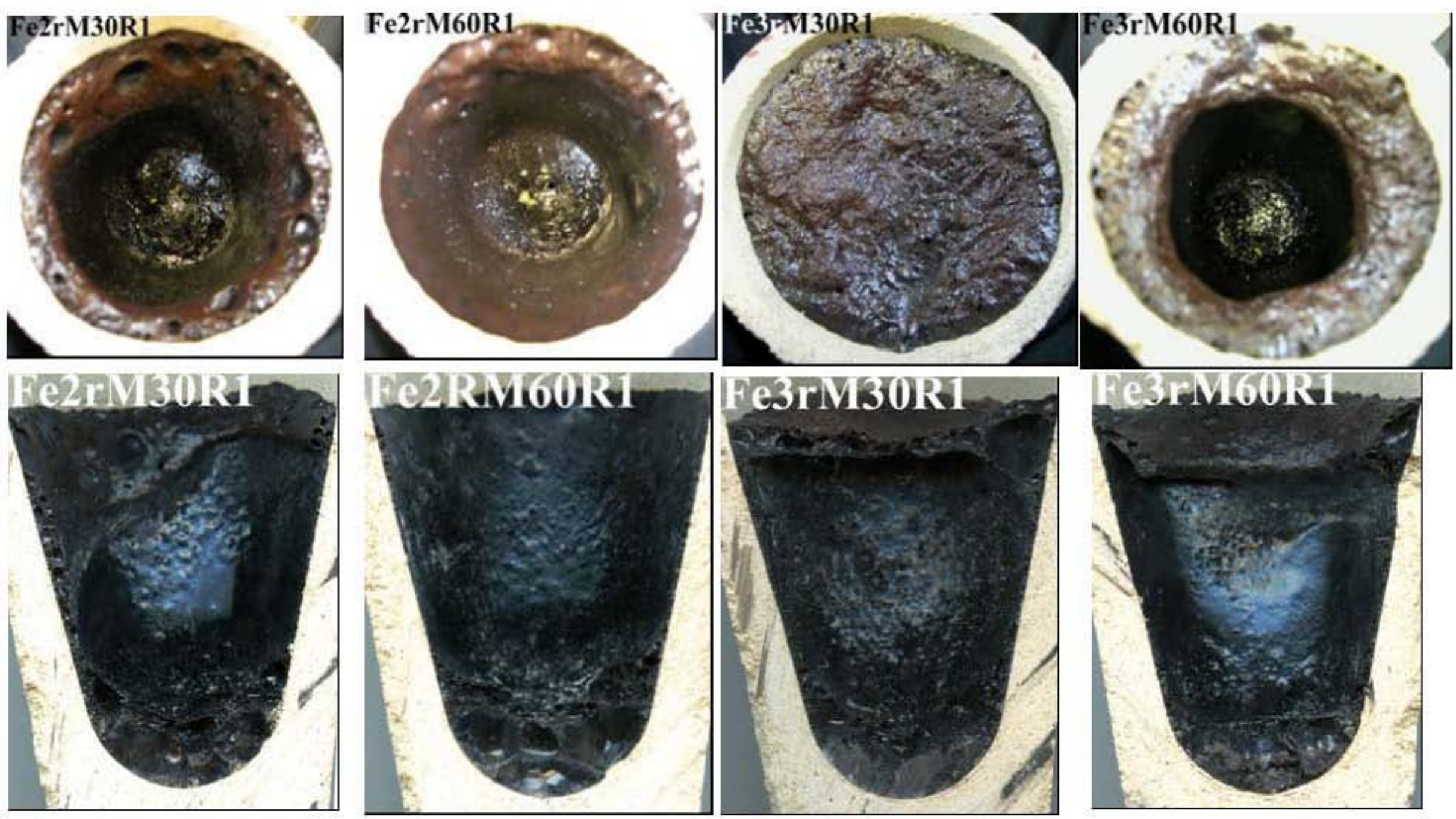

Figure 2.1. Top and cross section views of high iron feed samples after VGF experiments: c) HLW-NG-Fe2; d) HLW-NG-Fe3. 
e) HLW-NG-Fe4 (47 wt\% loading) $15 \mathrm{~min}$
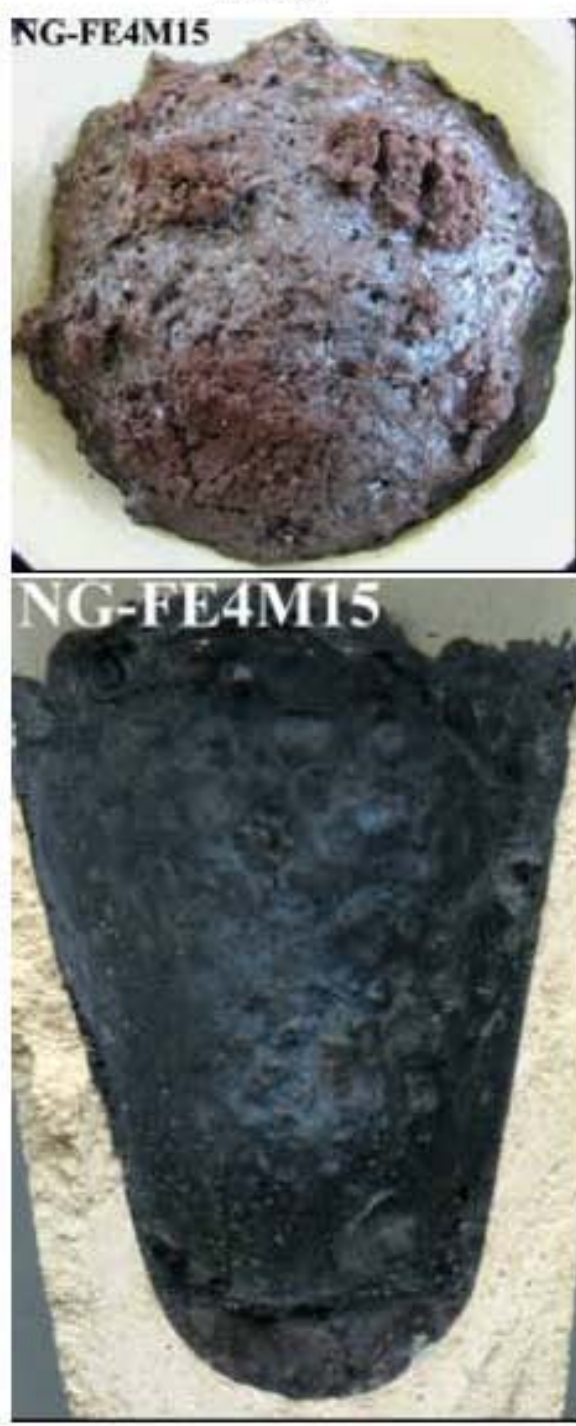

$30 \mathrm{~min}$
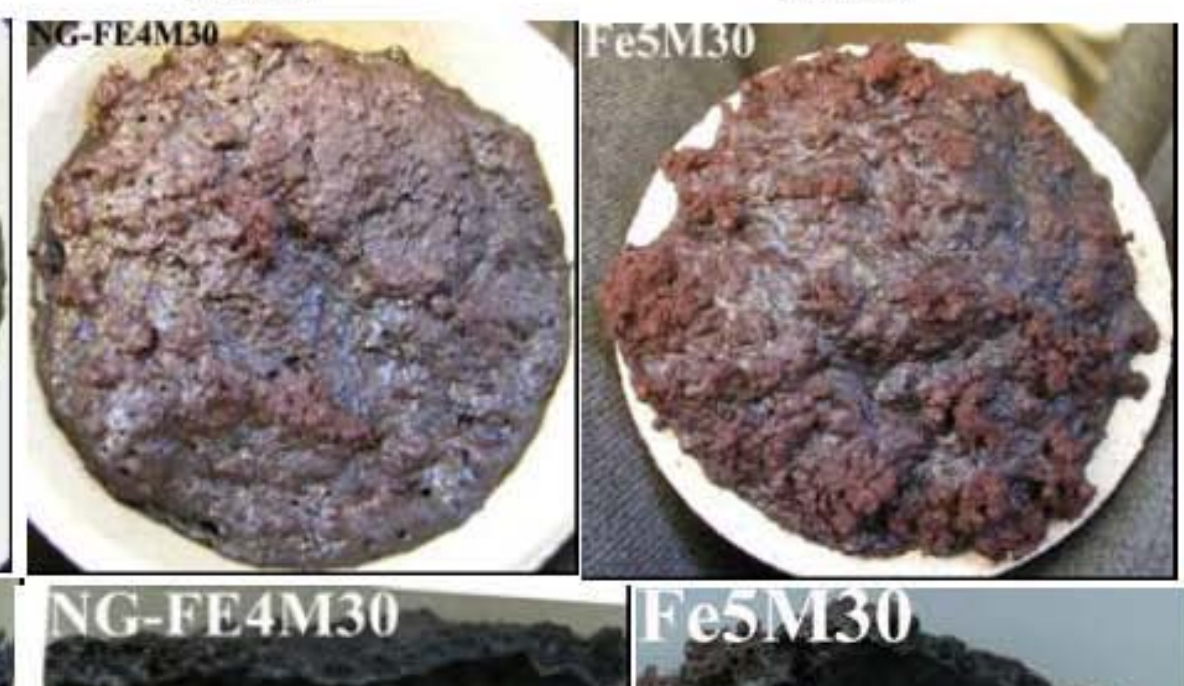

f) HLW-NG-Fe5 (47 wt\% loading)

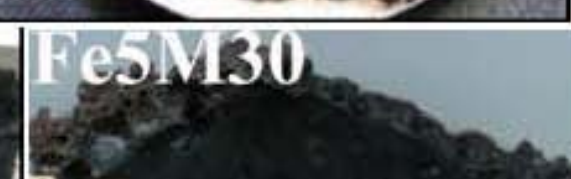

$30 \mathrm{~min}$

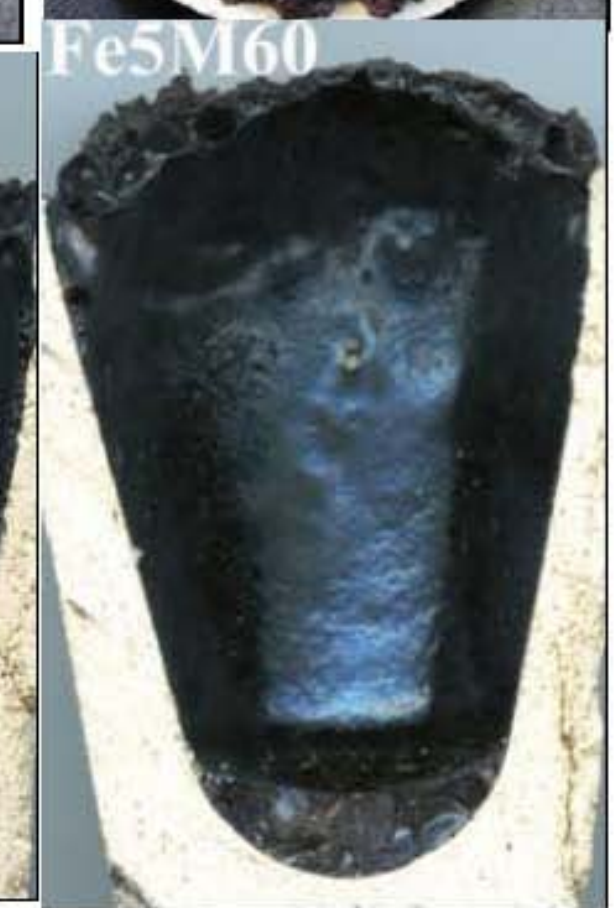

Figure 2.1.Top and cross section views of high iron feed samples after VGF experiments: e) HLW-NG-Fe4; f) HLW-NG-Fe5. 
g) HLW-NG-Fe6 (47 wt\% loading)

$30 \mathrm{~min}$
$60 \mathrm{~min}$ h) HLW-NG-Fe 7 (47 wt\% loading) $30 \mathrm{~min}$

$60 \mathrm{~min}$
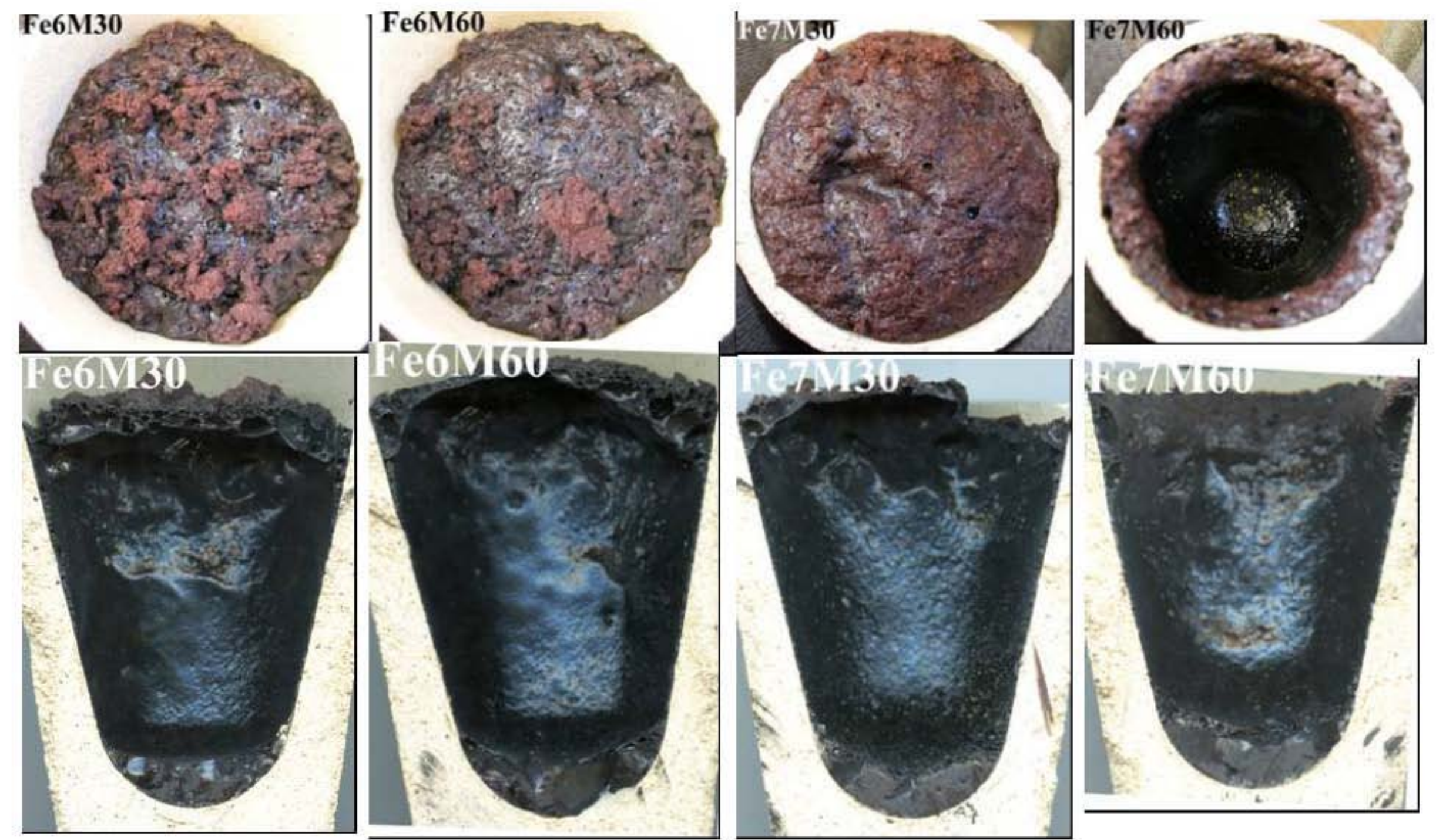

Figure 2.1. Top and cross section views of high iron feed samples after VGF experiments: g) HLW-NG-Fe6; h) HLW-NG-Fe7. 
i) HLW-NG-Fe9 (47 wt\% loading) $30 \mathrm{~min}$
$60 \mathrm{~min}$ j) HLW-NG-Fel0 (47 wt \% loading) $30 \mathrm{~min}$

$60 \mathrm{~min}$

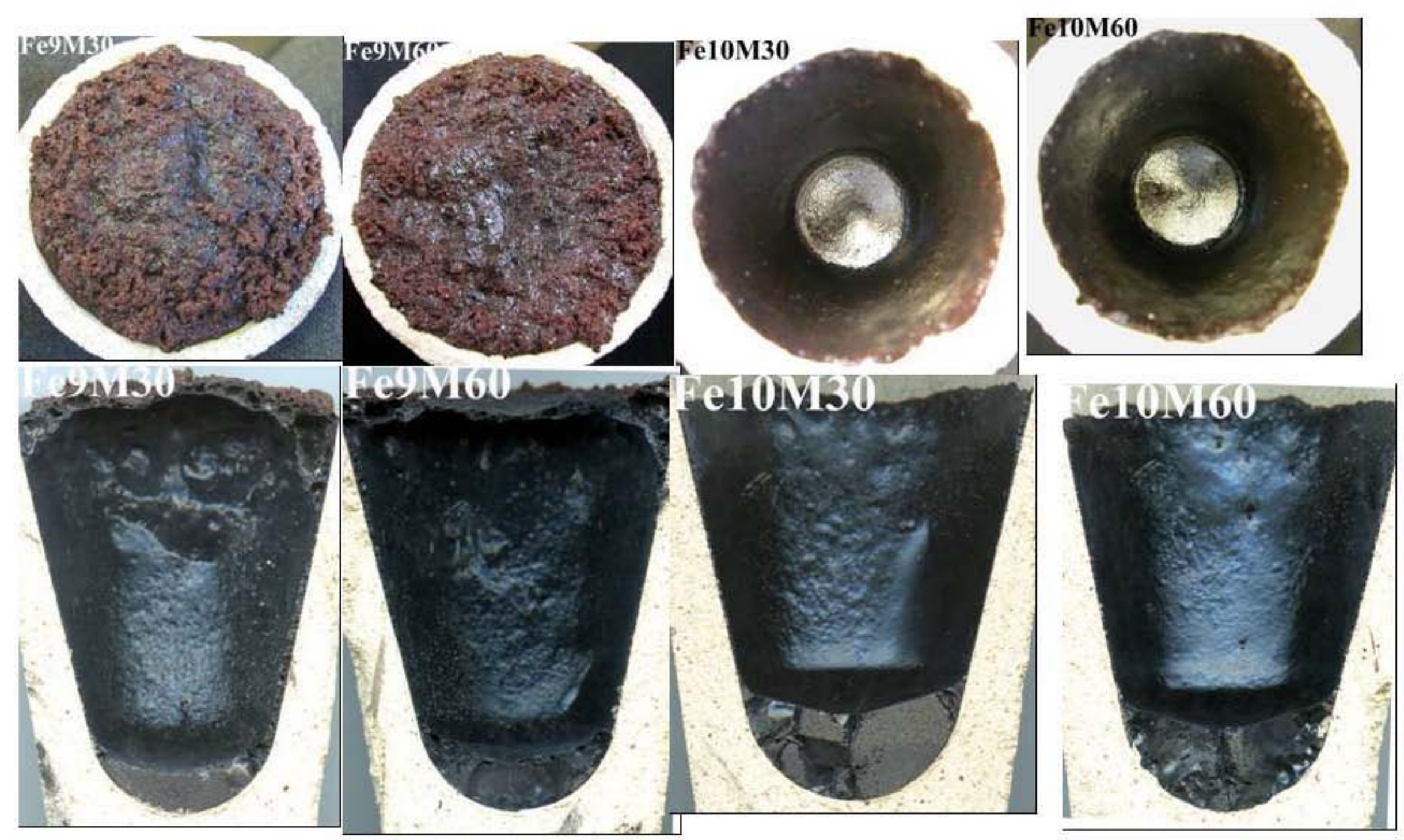

Figure 2.1. Top and cross section views of high ir on feed samples after VGF experim ents: i) HLW-NG-Fe9; j) HLW-NG-Fel0. 
k) HLW-NG-Fell (44 wt \% loading)

$30 \mathrm{~min}$
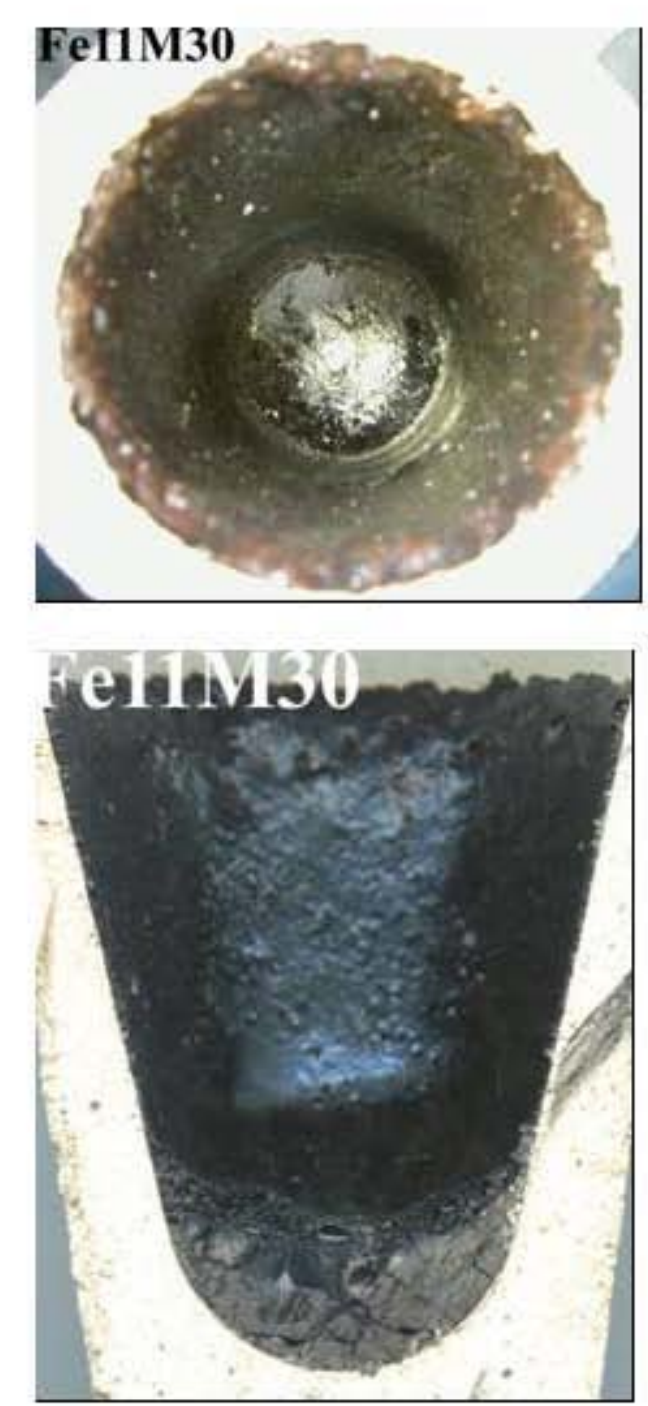

$60 \mathrm{~min}$

Figure 2.1. Top and cross section views of high iron feed samples after VGF experiments: k) HLW-NG-Fell. 


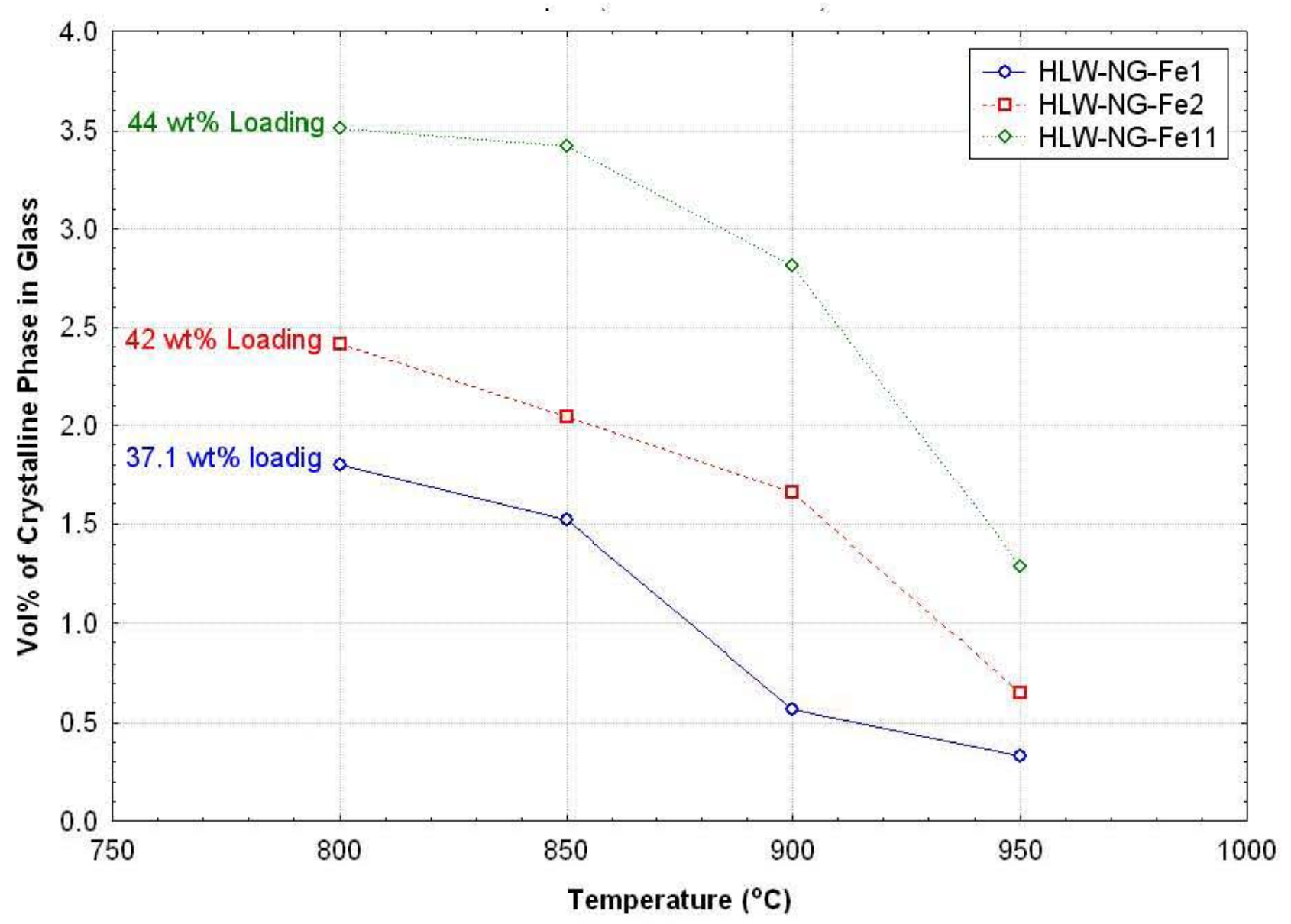

Figure 2.2. Crystallinity of high iron HLW glasses HLW-NG-Fe1, -Fe2 and-Fe11. 


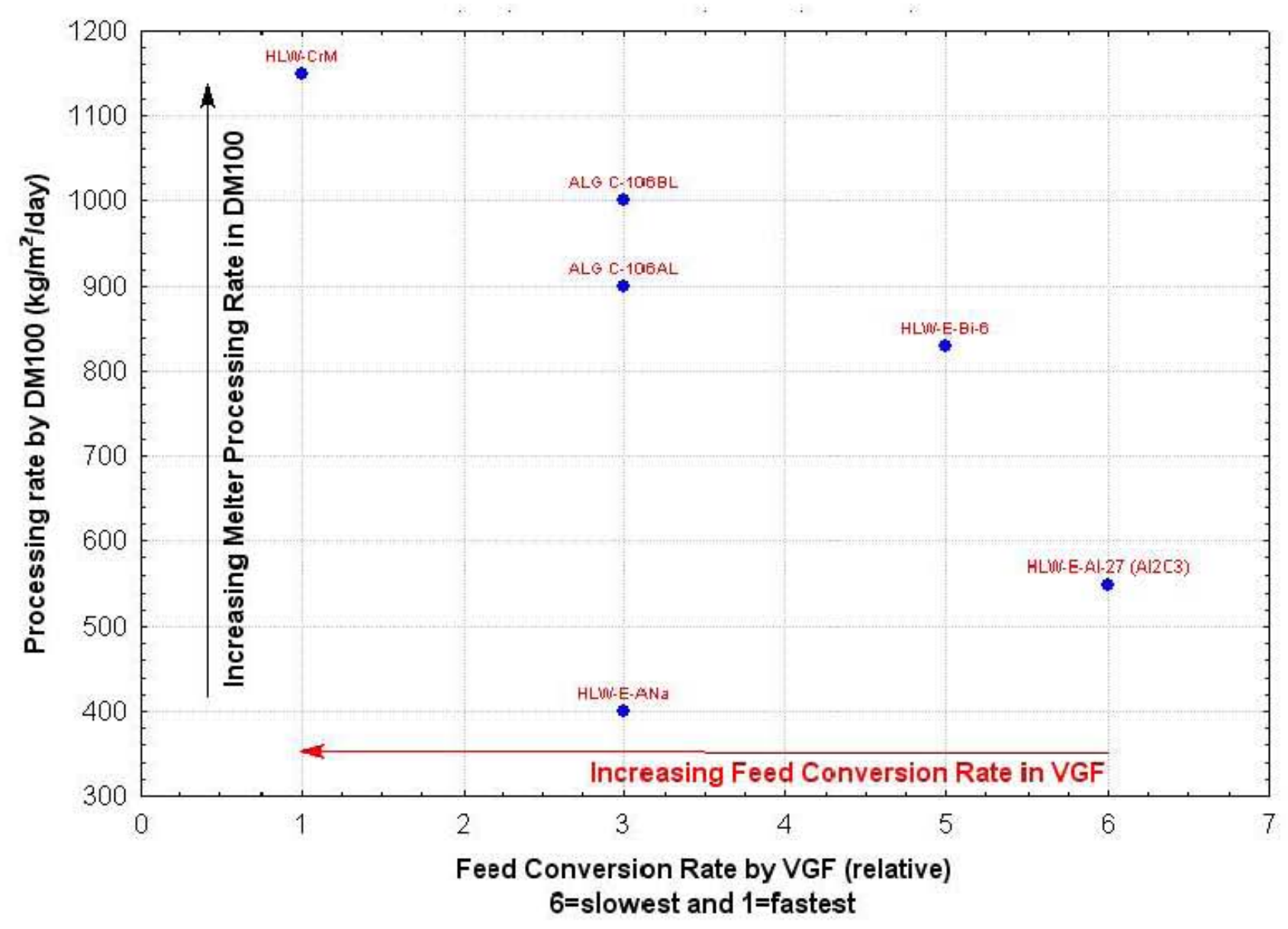

Figure 2.3. Evaluation of melt rate ranking by VGF as compared to the glass production rate determined by DM100 melter testing using the same melter feed. The definition of the V GF melt rate estimation is given in Table 2.7 (from [22]). 


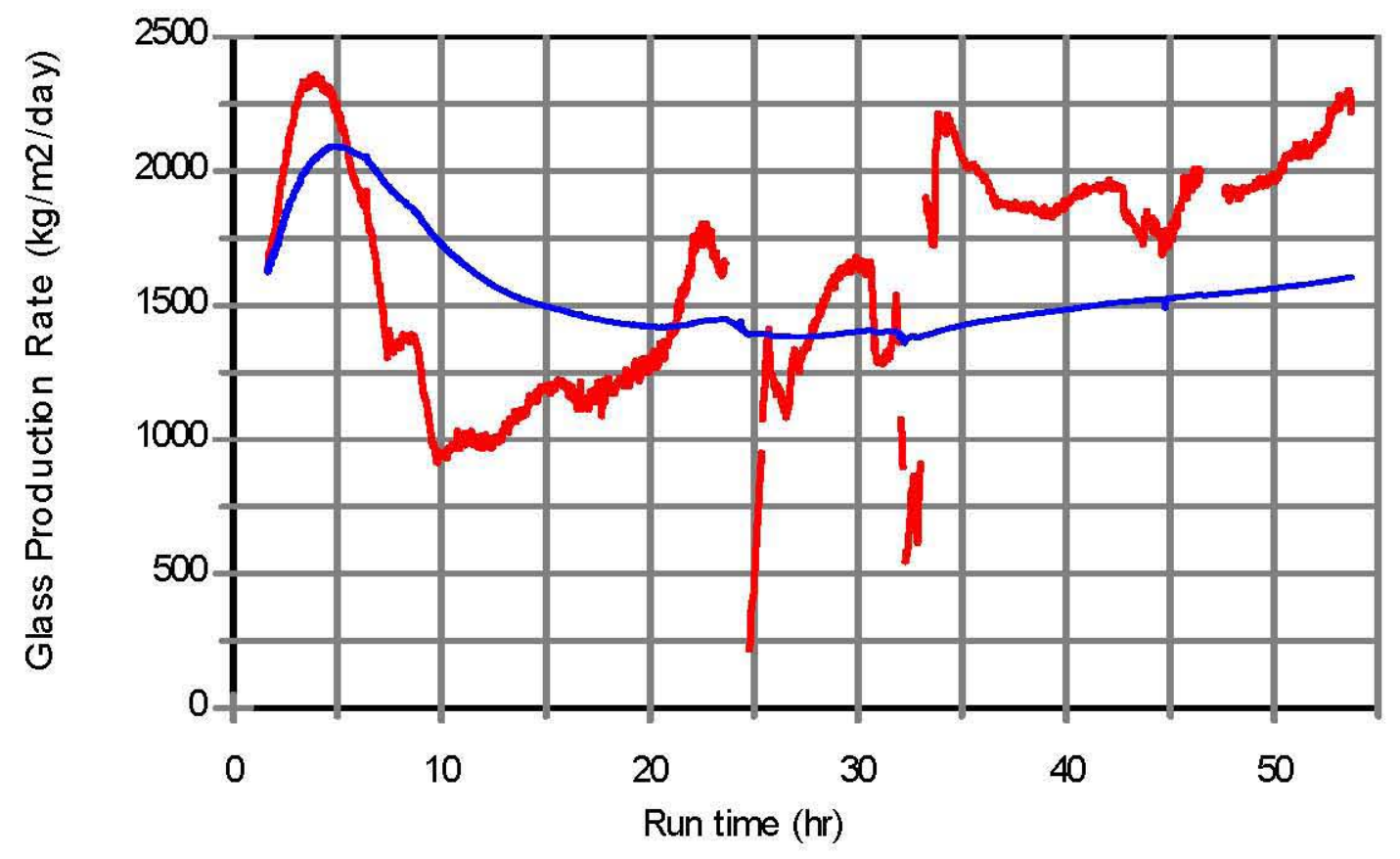

Figure 3.1.a. Glass production rates (hourly moving averages and cumulative) for DM100 test with optimized bubbling. 


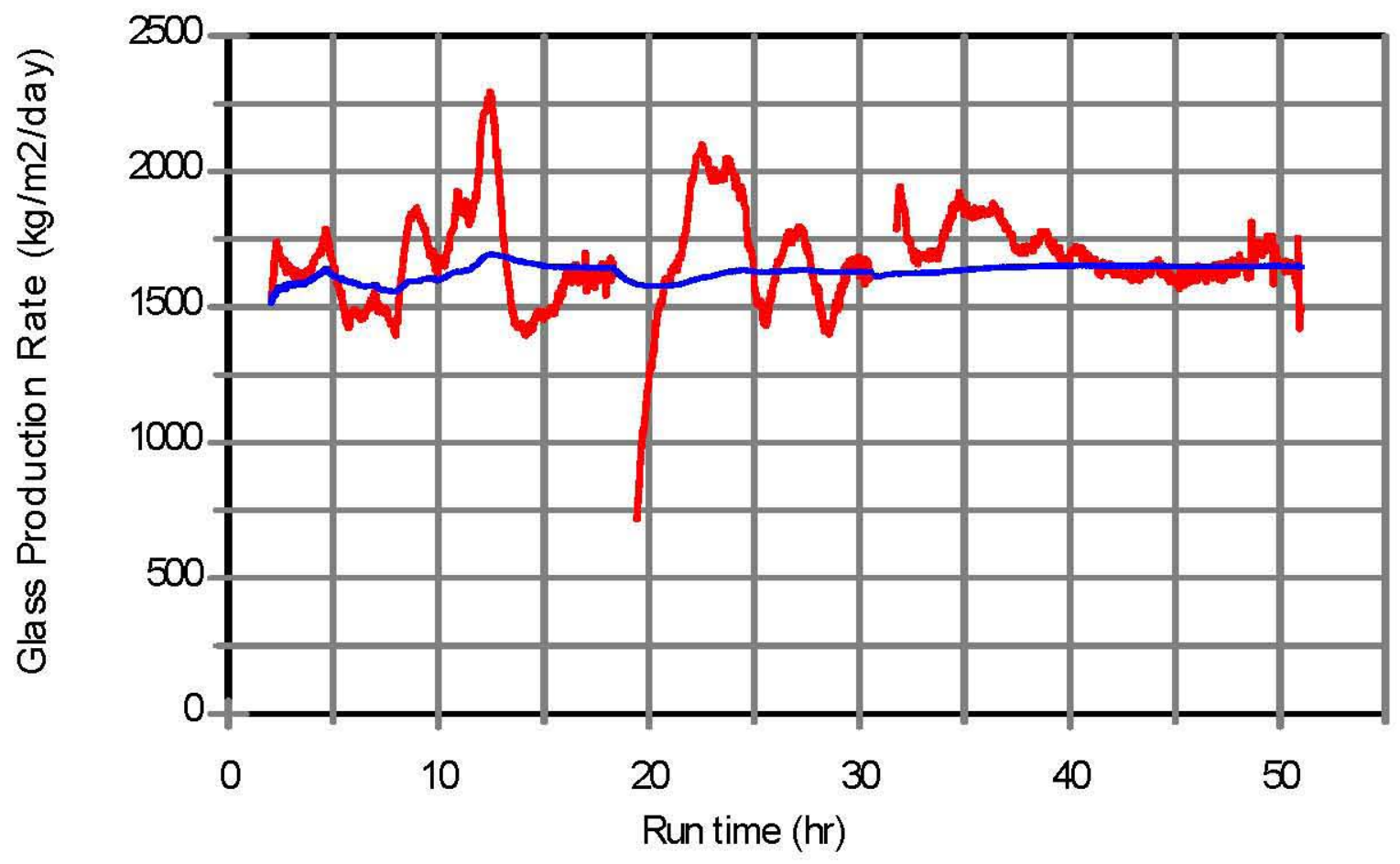

Figure 3.1.b. Glass production rates (hourly moving averages and cumulative) for DM100 test with 9 lpm bubbling. 


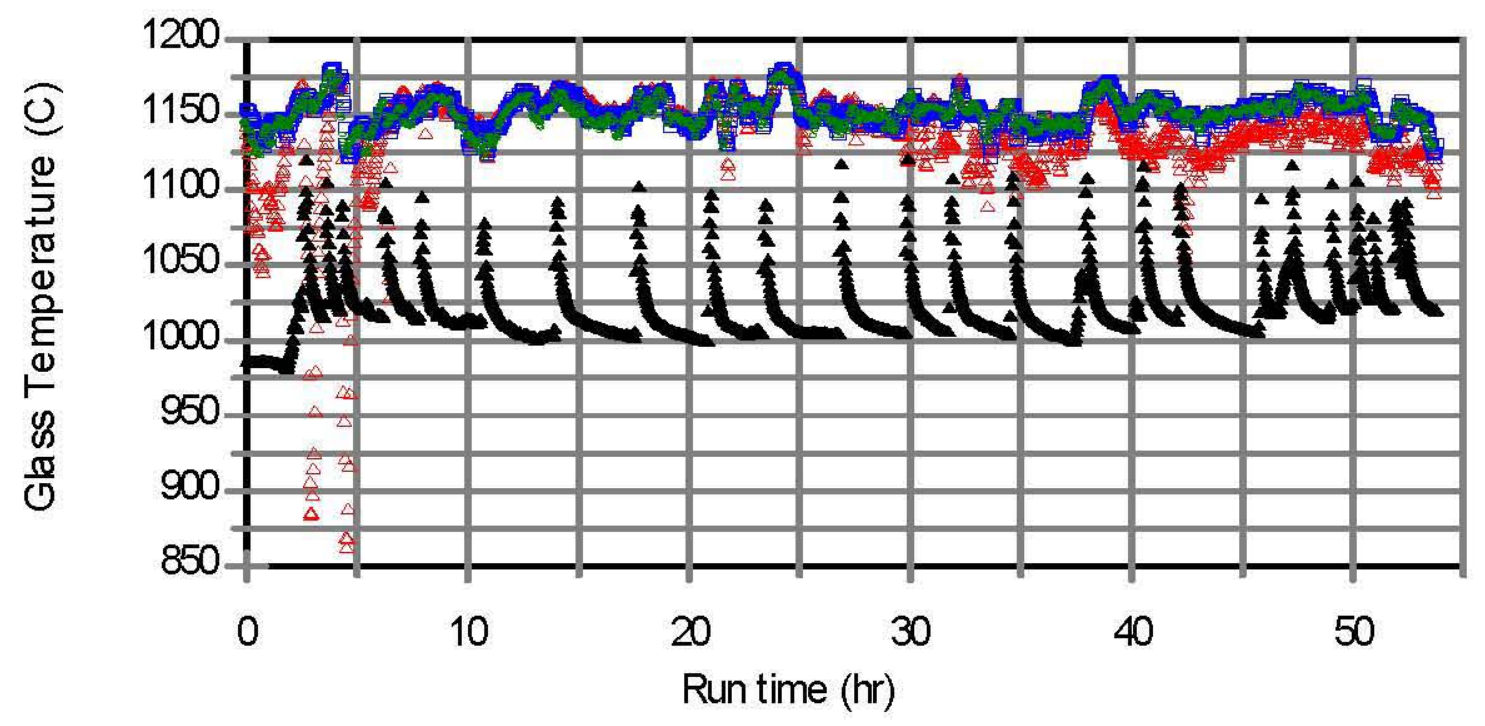

Figure 3.2.a. Glass temperatures (hourly averages) during DM100 test with optimized bubbling. 


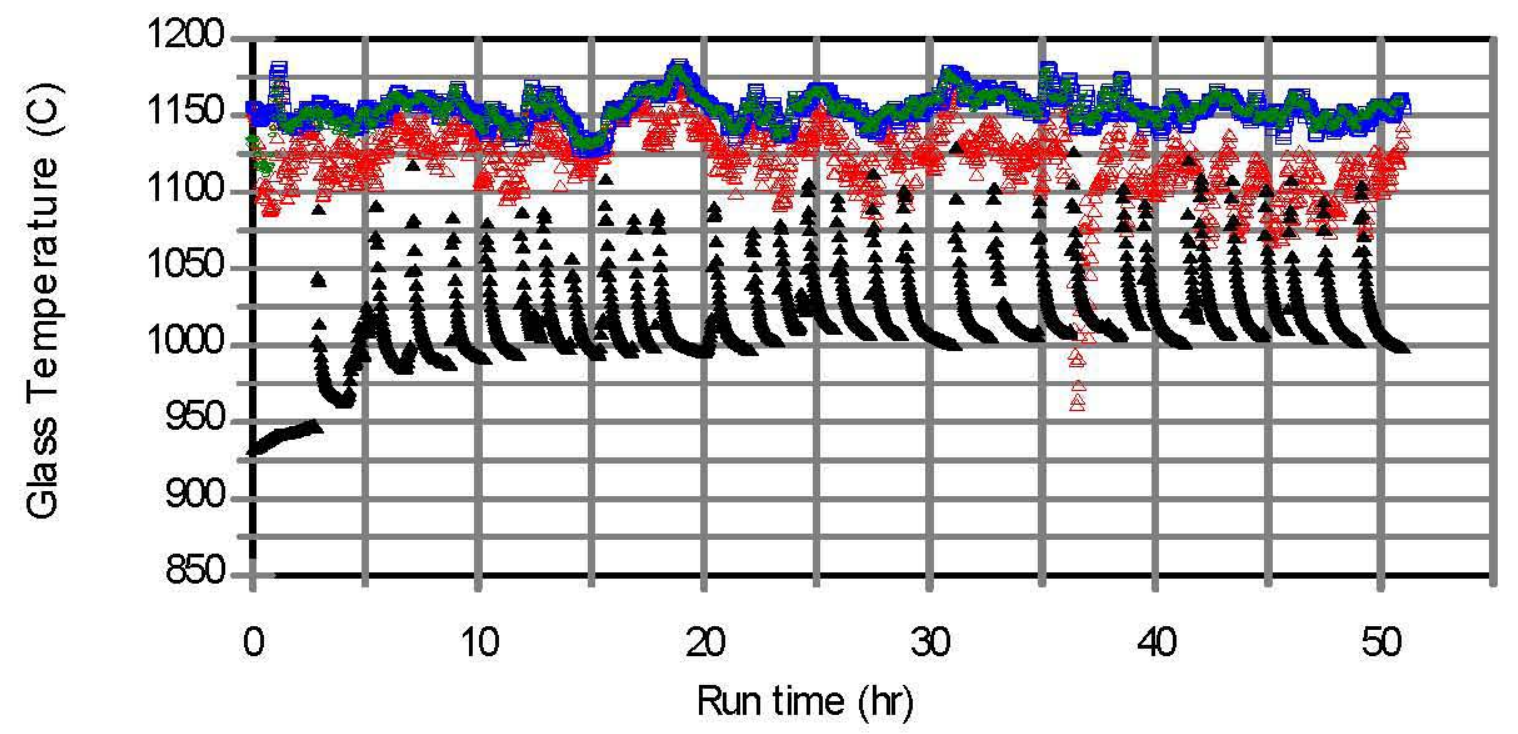

- $27^{\prime \prime}$ from bottom

- 10 " from bottom

- Airlift
- $16^{\prime \prime}$ from bottom

- 5 from bottom

Figure 3.2.b. Glass temperatures (hourly averages) during DM100 Test with $91 \mathrm{pm}$ bubbling. 


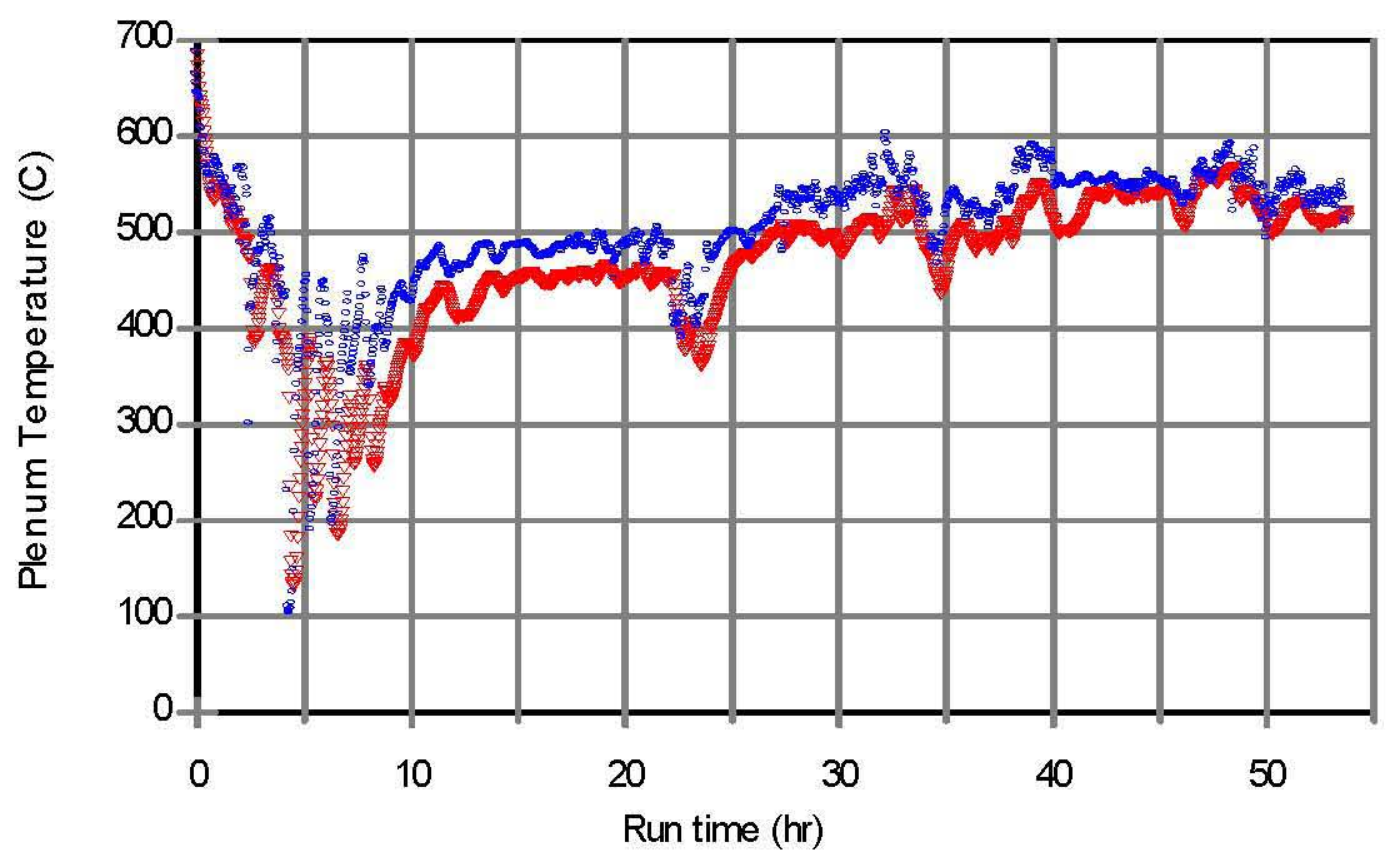

- 17 " from top, Thermowell

- $17^{\prime \prime}$ from top, Exposed

Figure 3.3.a. Plenum temperatures (hourly averages) during DM100 test with optimized bubbling. 


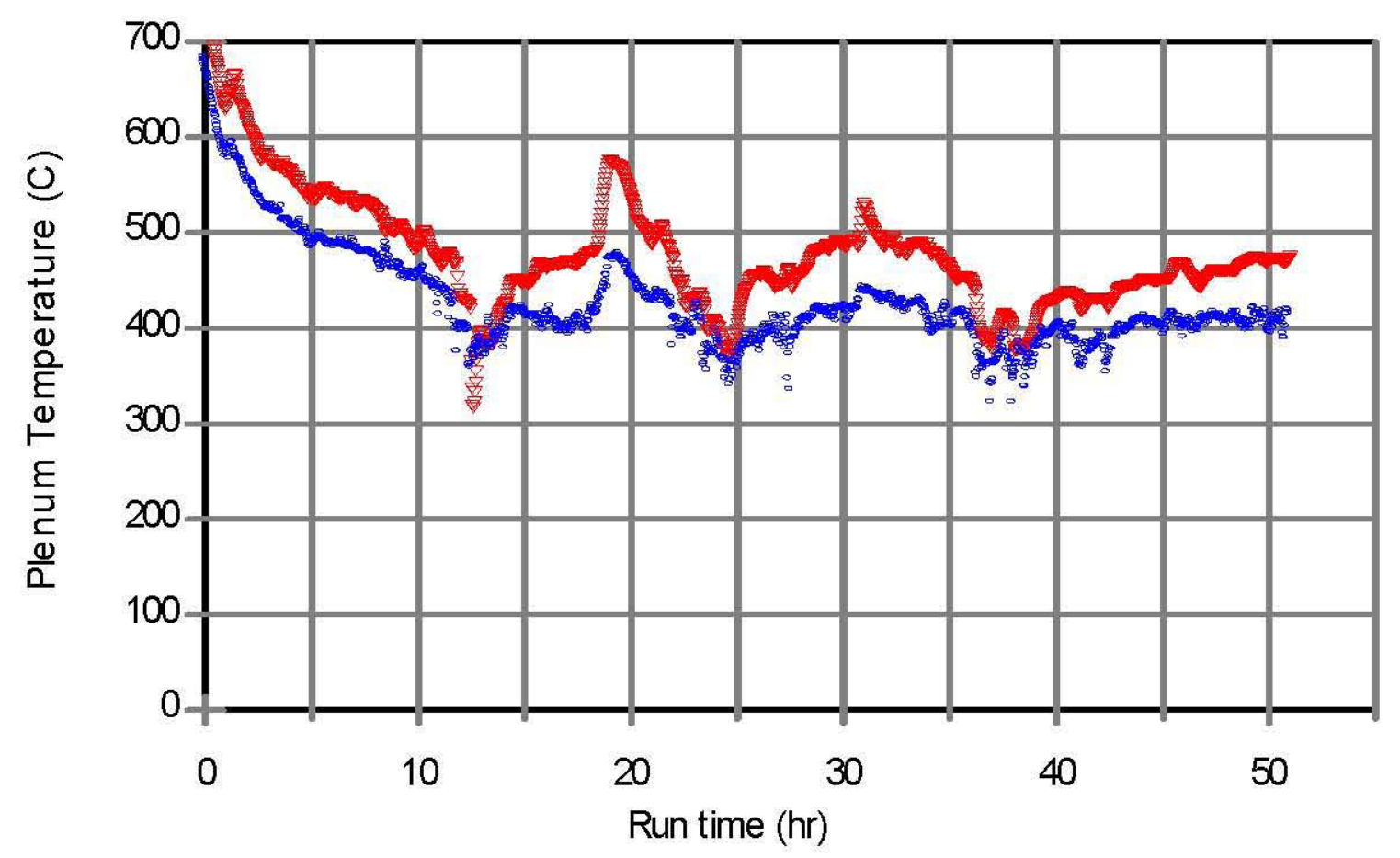

- 17" from top, Thermowell

- $17^{\prime}$ from top, Exposed

Figure 3.3.b. Plenum temperatures (hourly averages) during DM100 test with 9 lpm bubbling. 


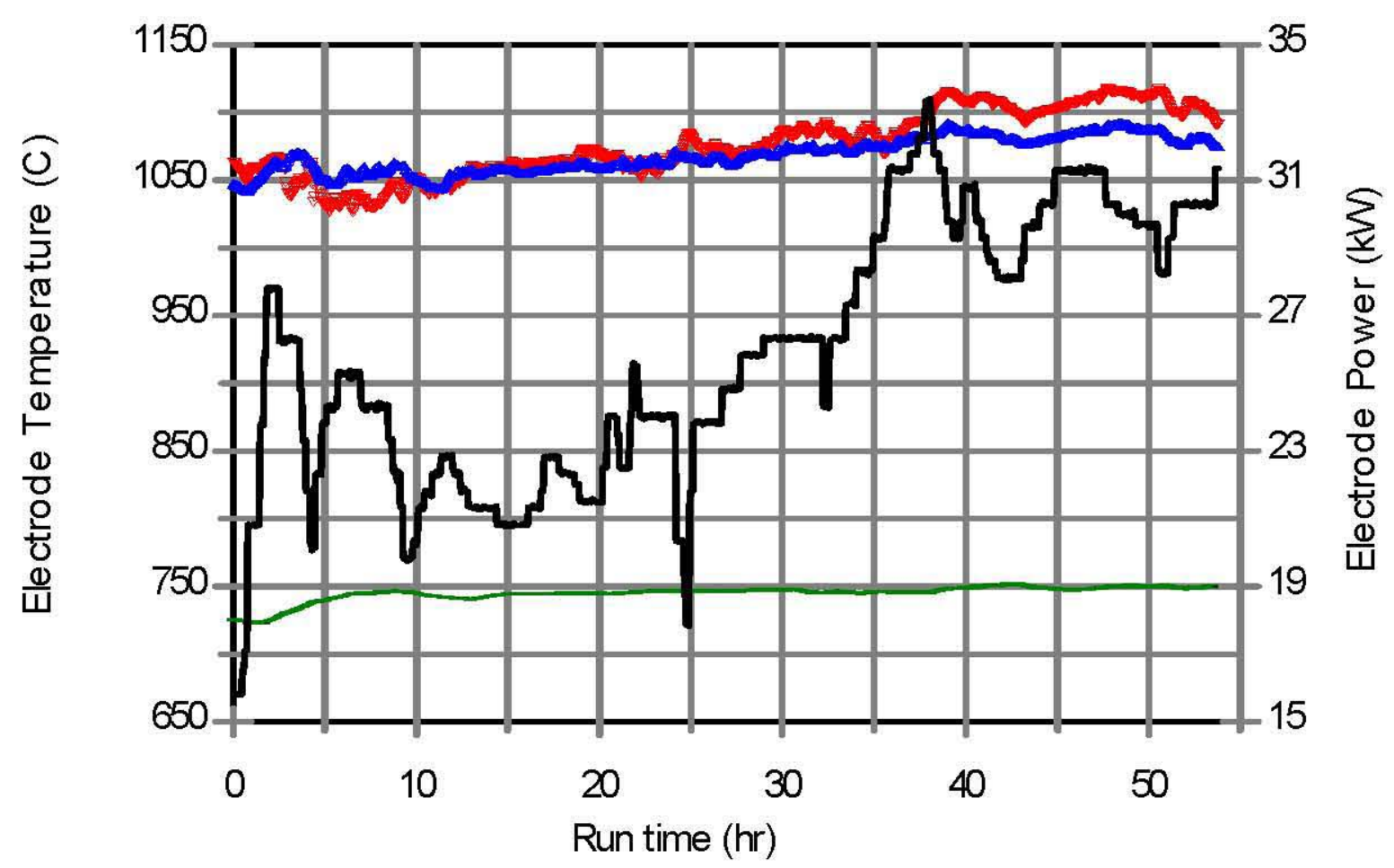

Figure 3.4.a. Electrode temperatures and power (hourly averages) during DM100 test with optimized bubbling. 

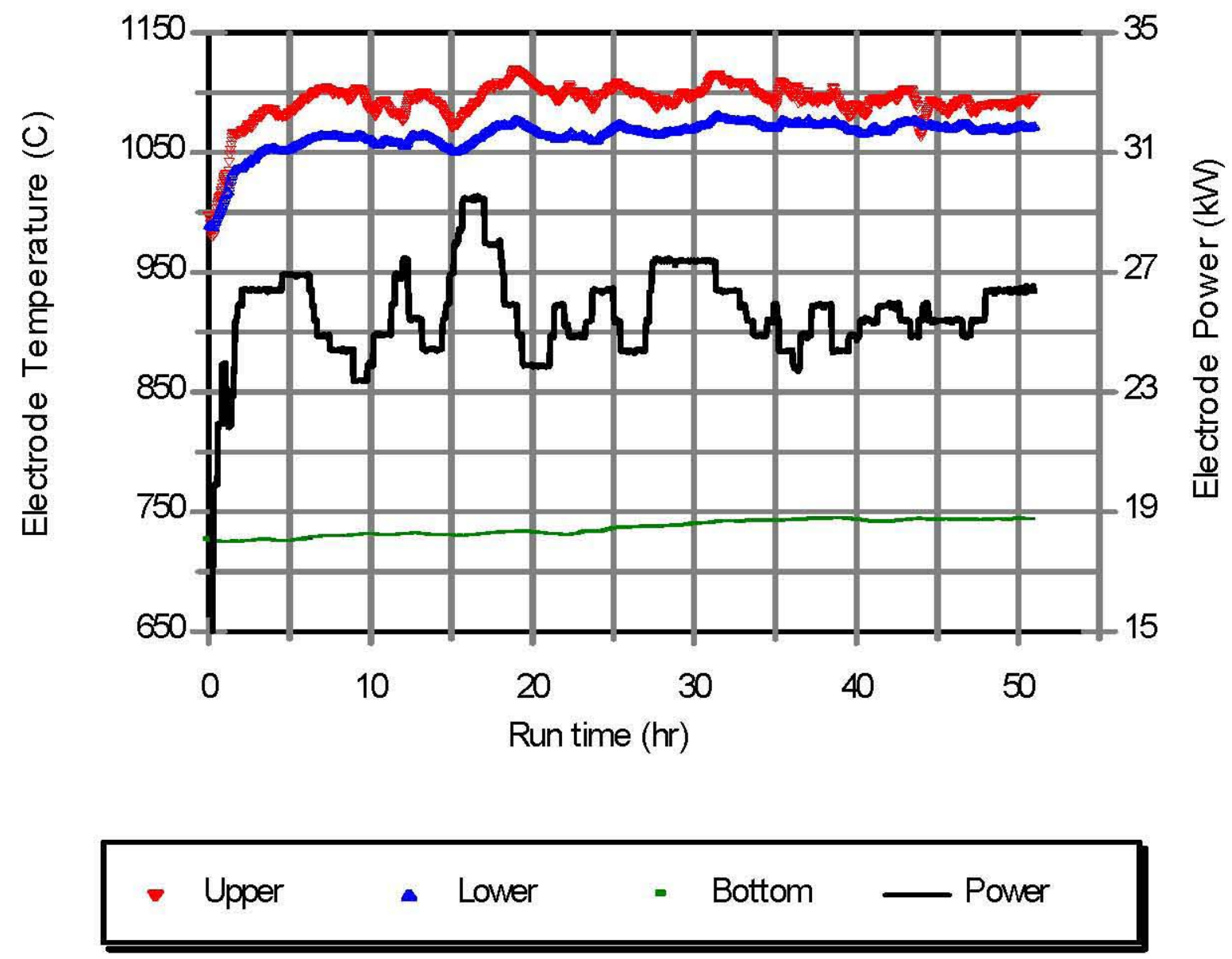

Figure 3.4.b. Electrode temperatures and power (hourly averages) during DM100 test with 9 lpm bubbling. 


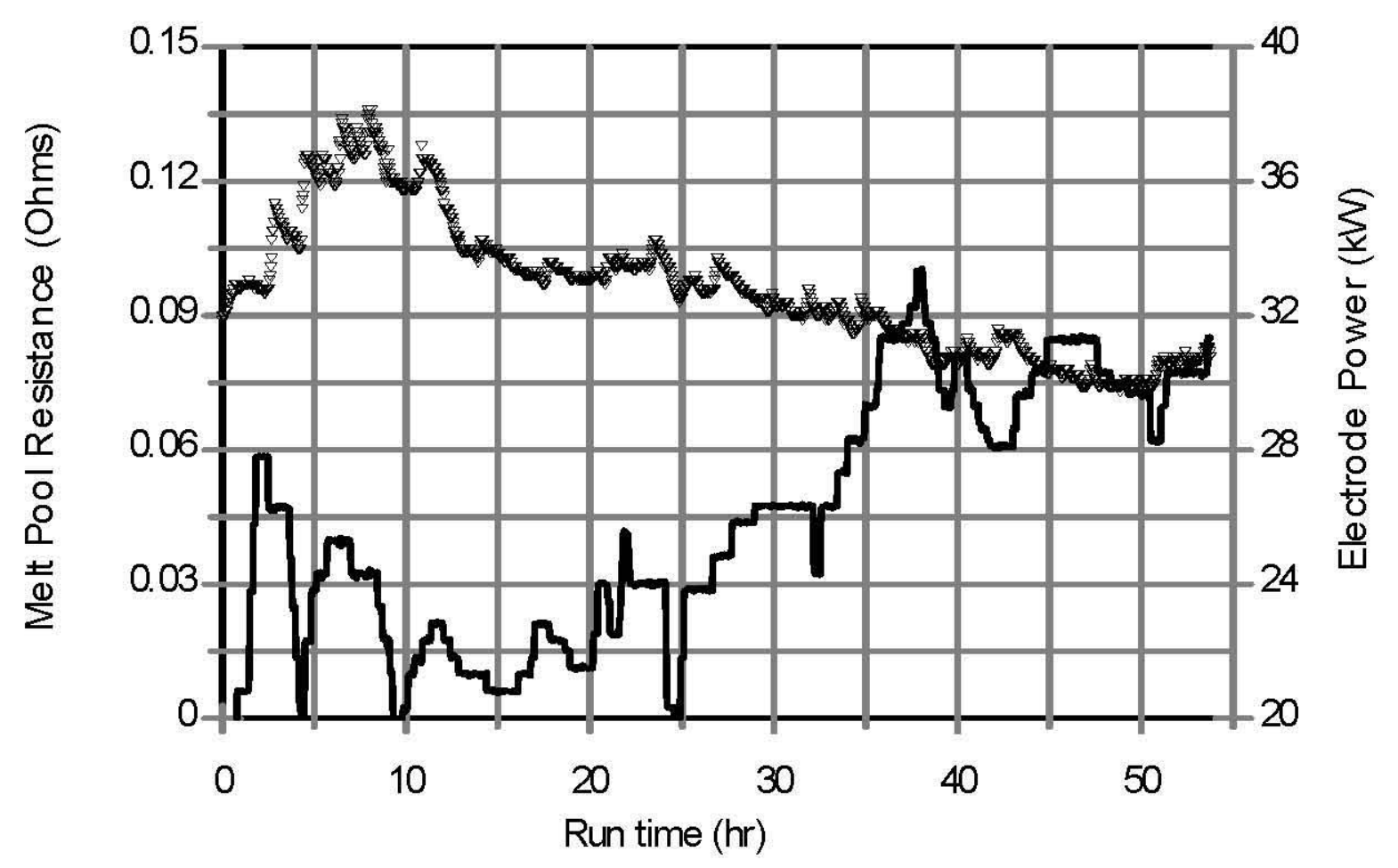

Figure 3.5.a. Melt pool resistance and total electrode power during DM100 test with optimized bubbling. 


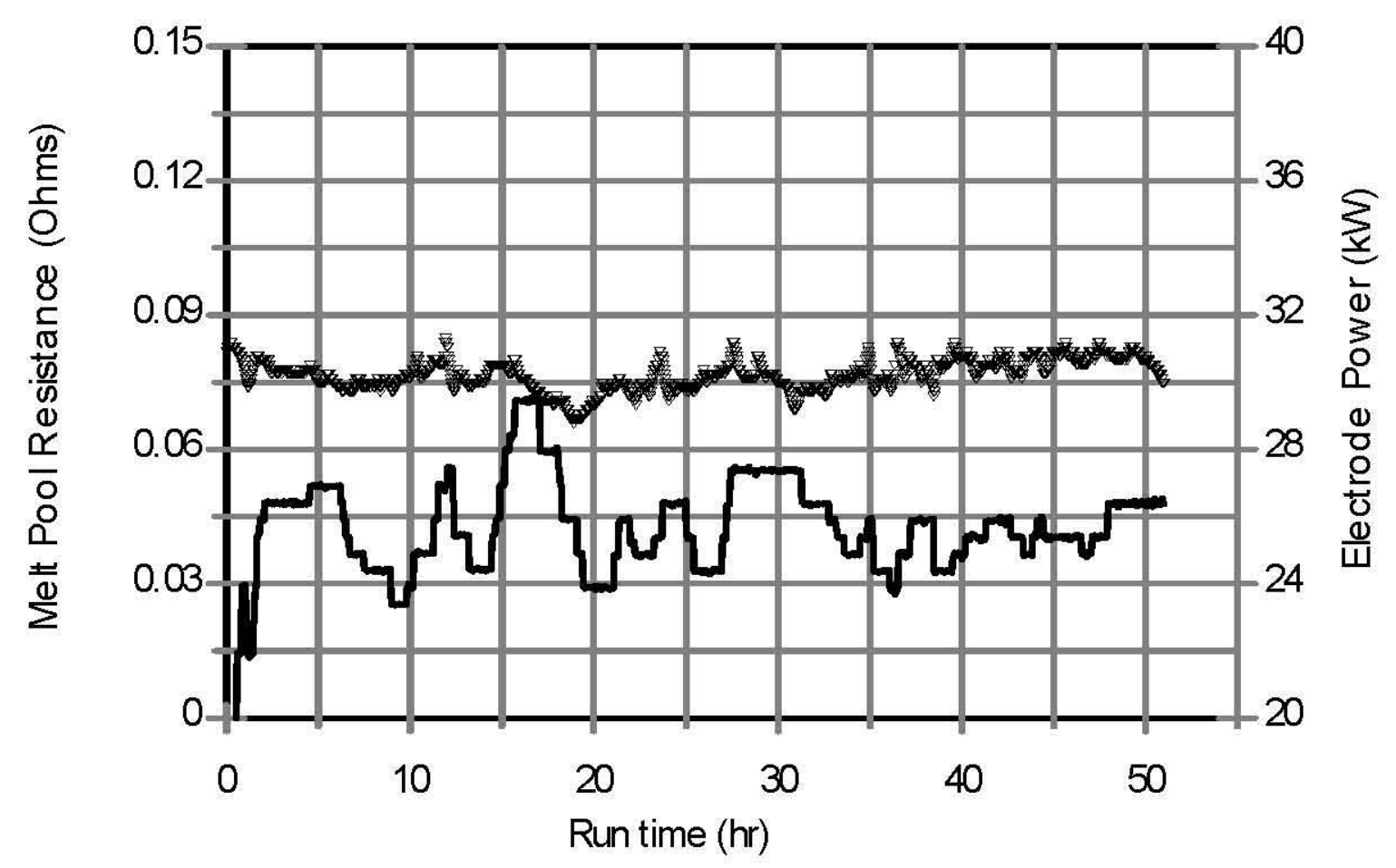

Figure 3.5.b. Melt pool resistance and total electrode power during DM100 test with 9 lpm bubbling. 


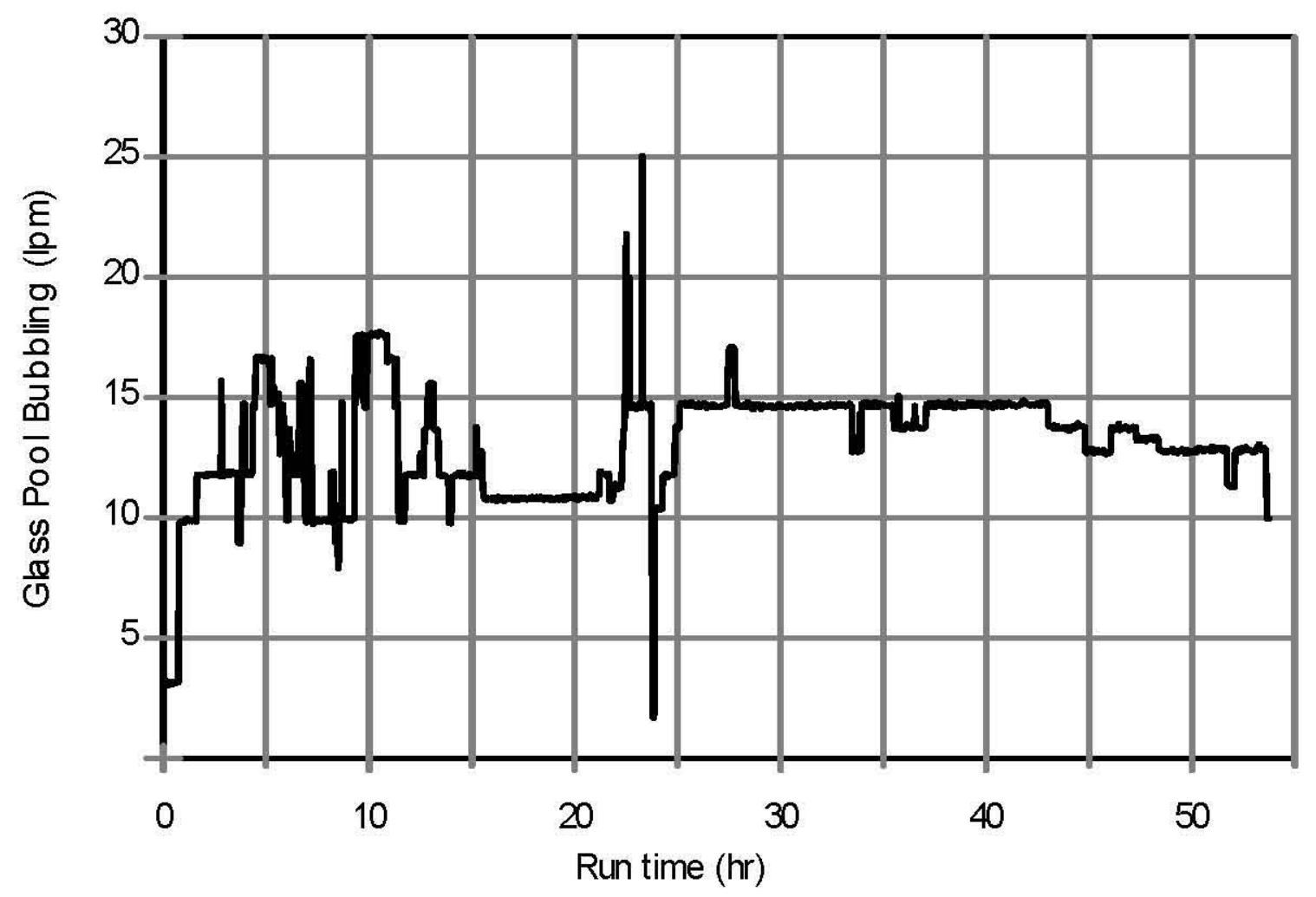

Figure 3.6.a. Melt pool bubbling during DM100 test with optimized bubbling. 


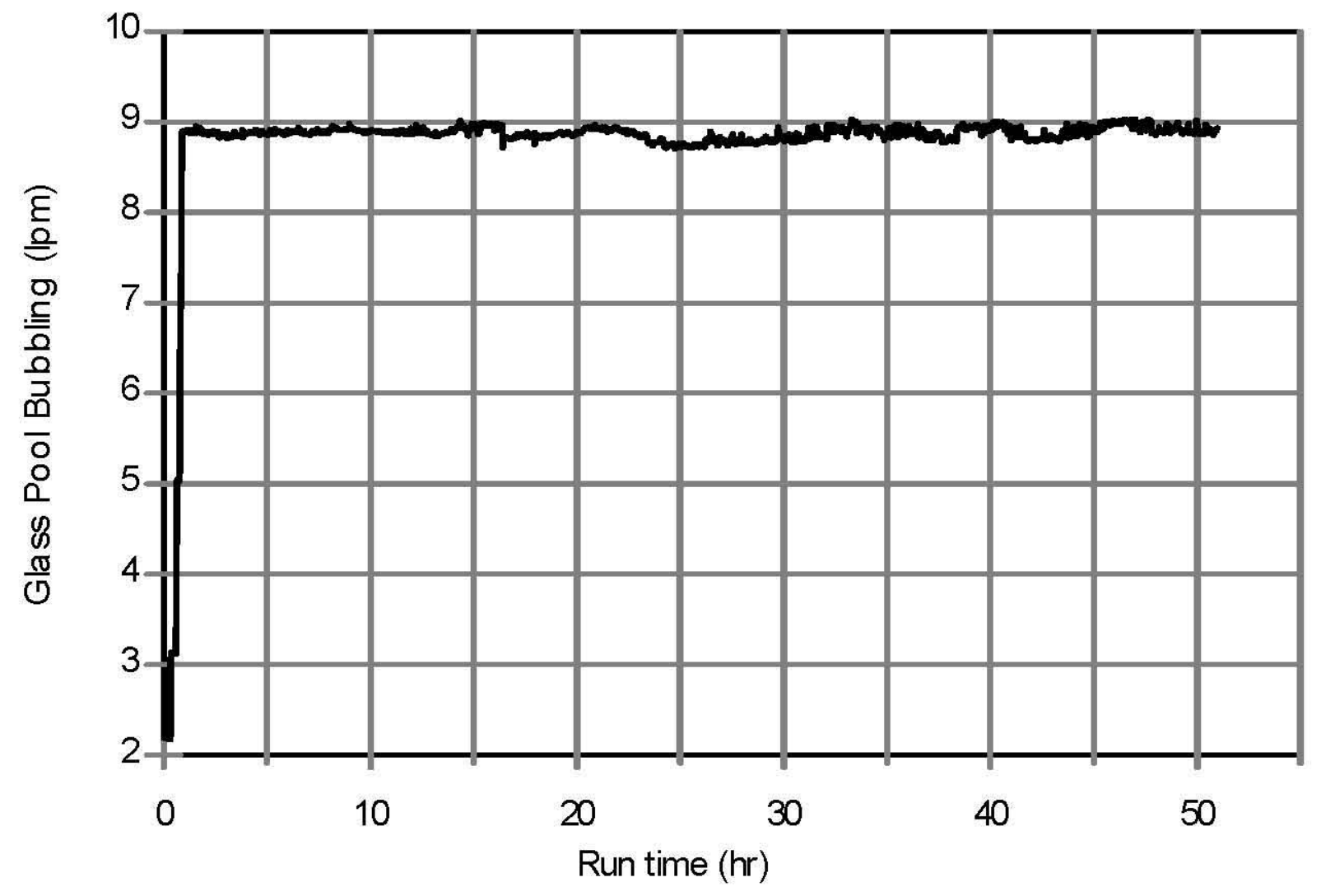

Figure 3.6.b. Melt pool bubbling during DM100 test with $91 \mathrm{pm}$ bubbling. 


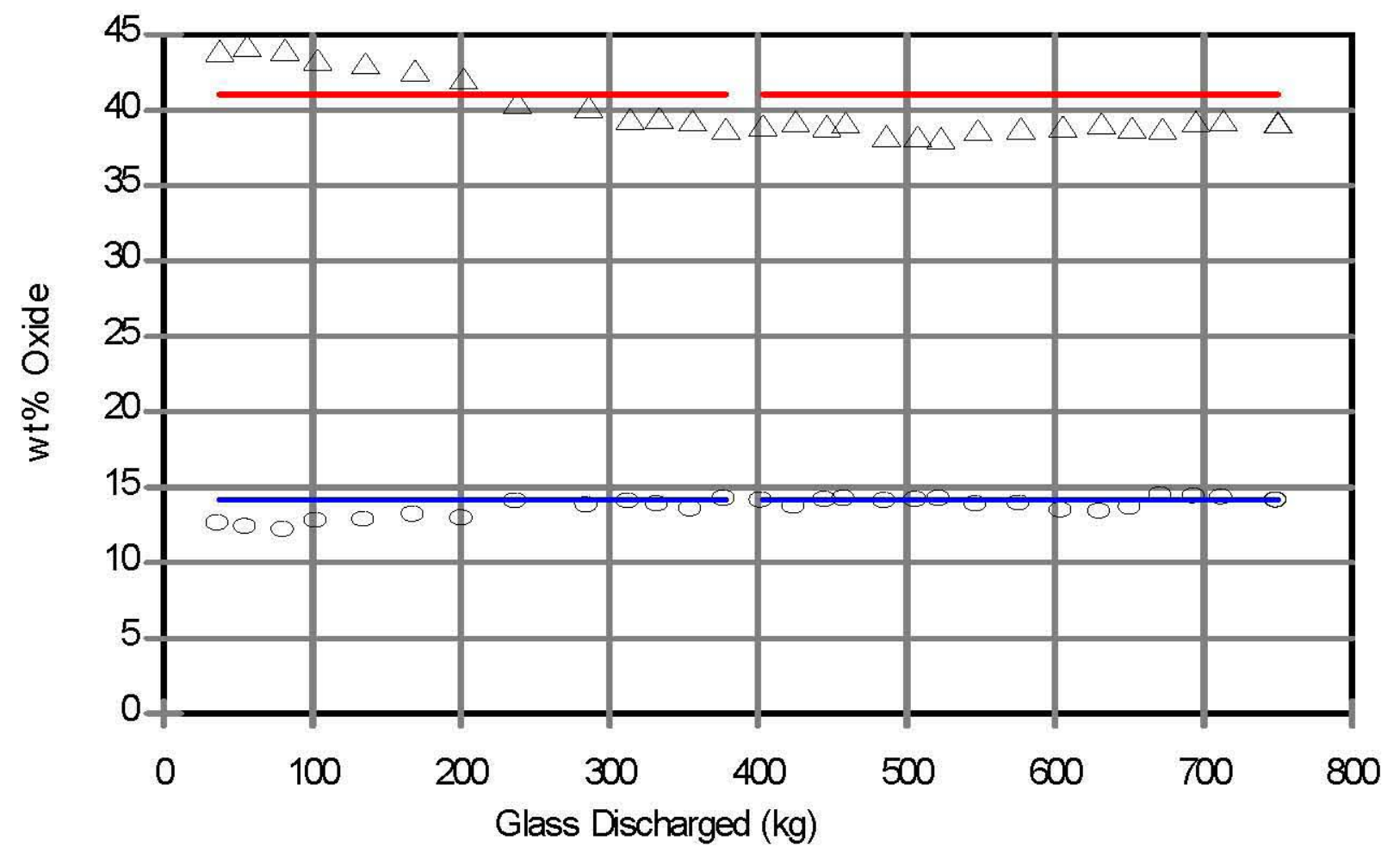

- Na Measured - Na Target

$\Delta$ Si Measured Si Target

Figure 4.1.a. DM100 product and target glass compositions determined by XRF. 
The Catholic University of America Vitreous State Laboratory
Melt Rate Enhancement for High Aluminum HLW Glass Formulations

Final Report, VSL-08R1360-1, Rev. 0

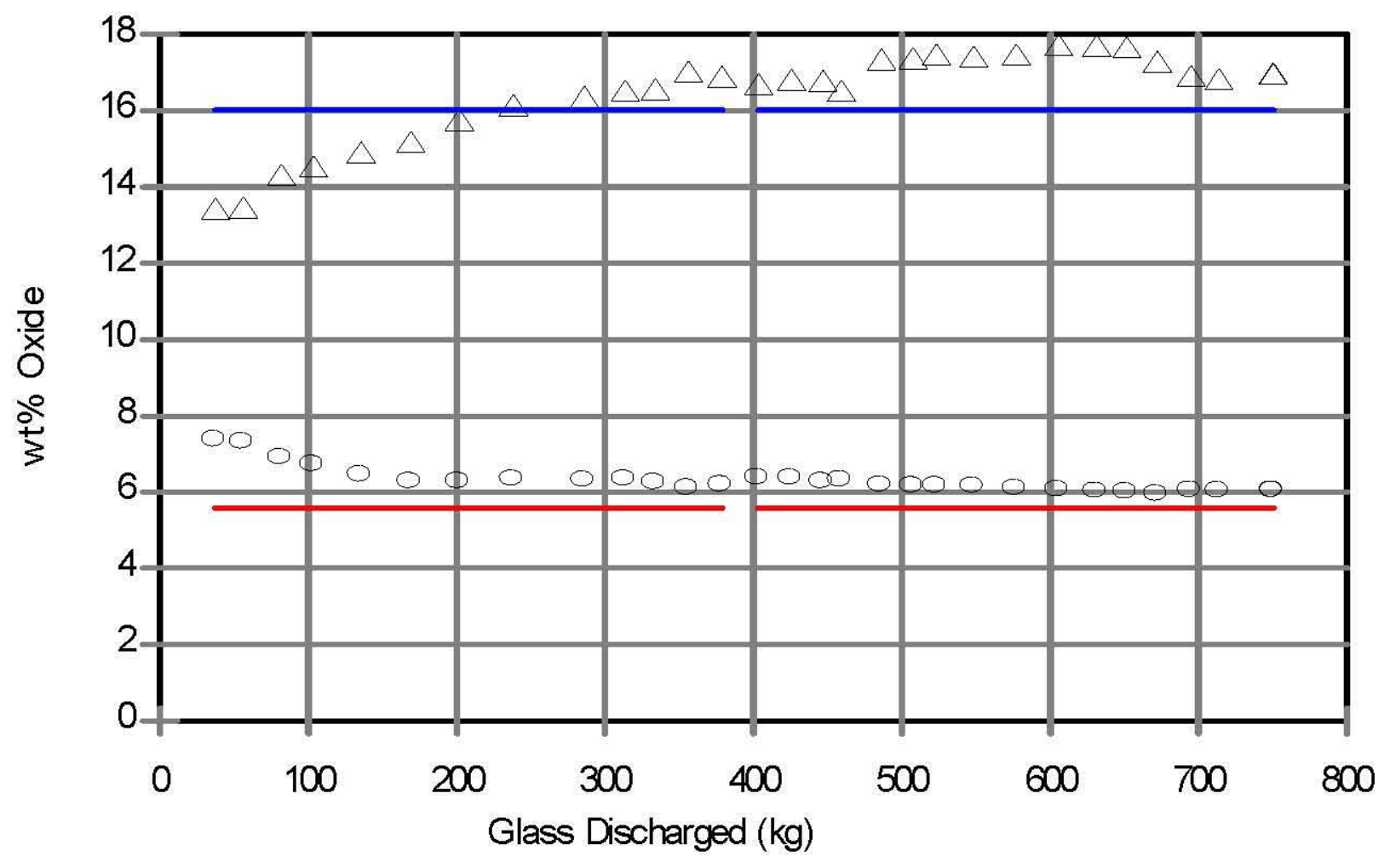

- AlMeasured

Figure 4.1.b. DM100 product and target glass compositions determined by XRF. 
The Catholic University of America Vitreous State Laboratory
Melt Rate Enhancement for High Aluminum HLW Glass Formulations

Final Report, VSL-08R1360-1, Rev. 0

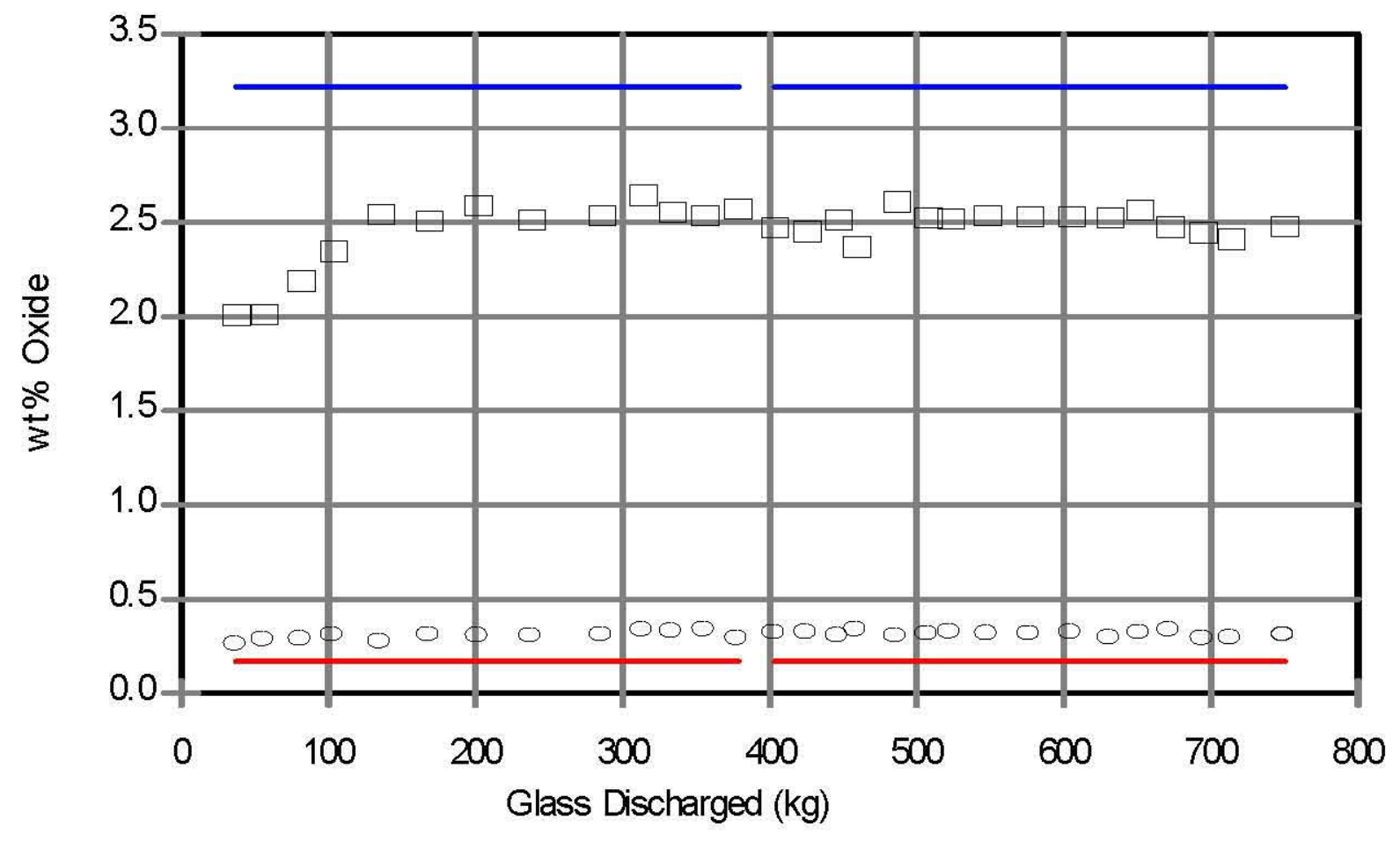

口 Mn Measured $\quad$ Mn Target $\quad$ Mg Measured $\quad$ Mg Target

Figure 4.1.c. DM100 product and target glass compositions determined by XRF. 
The Catholic University of America Vitreous State Laboratory
Melt Rate Enhancement for High Aluminum HLW Glass Formulations

Final Report, VSL-08R1360-1, Rev. 0

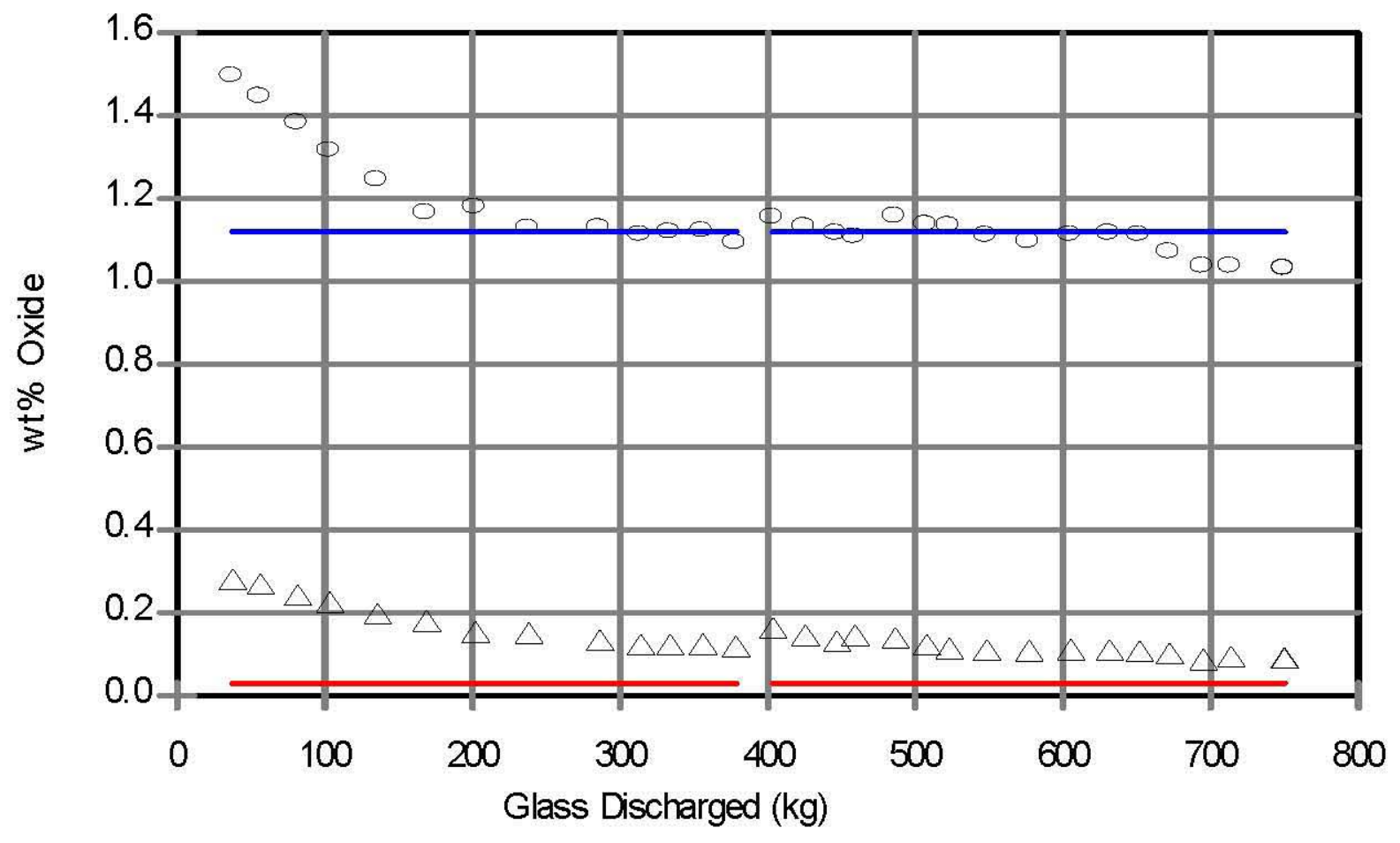

$\Delta$ Zn Measured Z ZnTarget

- Zr Measured

Figure 4.1.d. DM100 product and target glass compositions determined by XRF. 
The Catholic University of America Vitreous State Laboratory
Melt Rate Enhancement for High Aluminum HLW Glass Formulations

Final Report, VSL-08R1360-1, Rev. 0

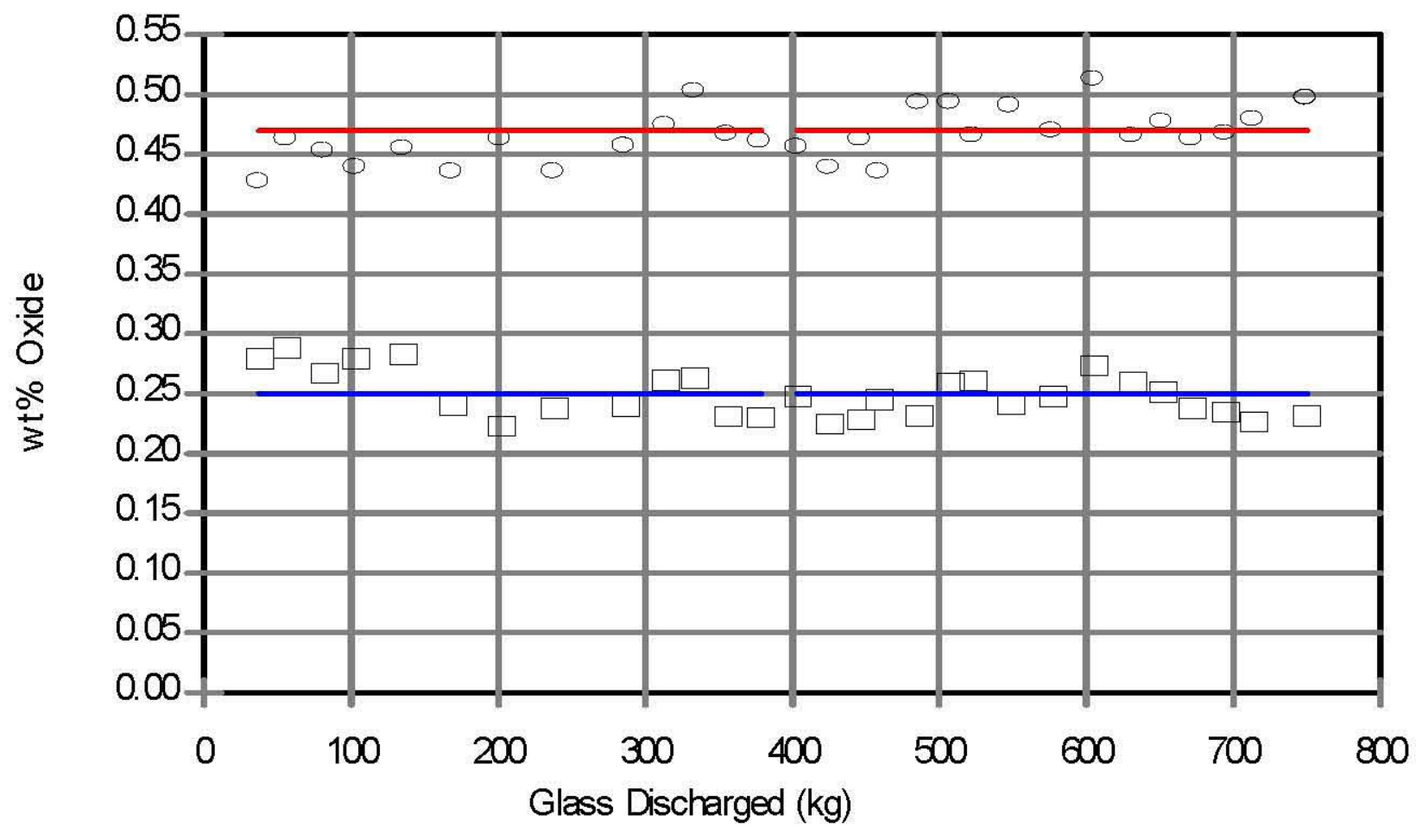

$\square$ Cr Measured $\longrightarrow$ Cr Target

- Ni Measured

NiTarget

Figure 4.1.e. DM100 product and target glass compositions determined by XRF. 
The Catholic University of America Vitreous State Laboratory
Melt Rate Enhancement for High Aluminum HLW Glass Formulations

Final Report, VSL-08R1360-1, Rev. 0

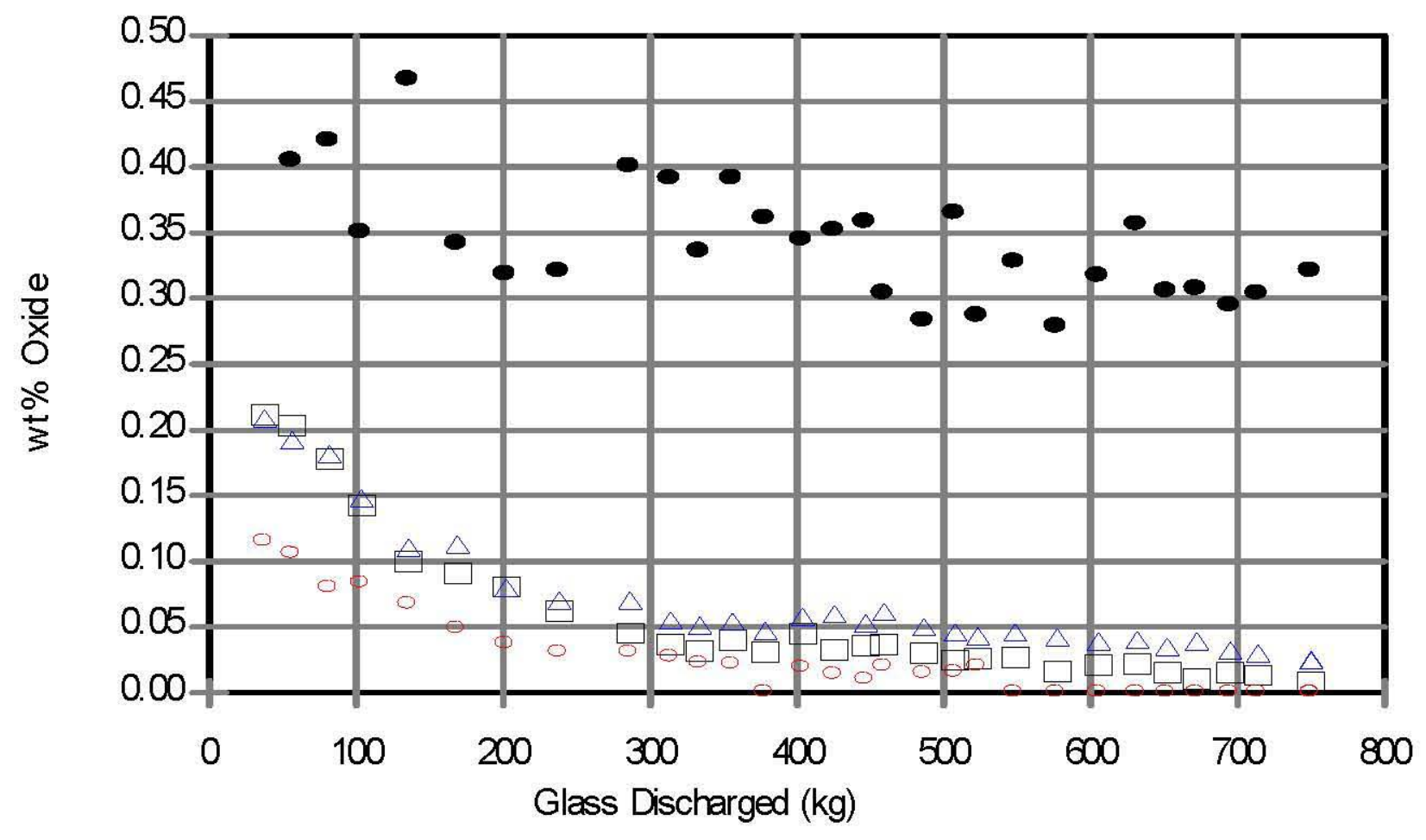

口 Bi Measured

$\Delta$ Cd Measured

- KMeasured

- VMeasured

Figure 4.1.f. DM100 product and target glass compositions determined by XRF. 
The Catholic University of America Vitreous State Laboratory
Melt Rate Enhancement for High Aluminum HLW Glass Formulations

Final Report, VSL-08R1360-1, Rev. 0

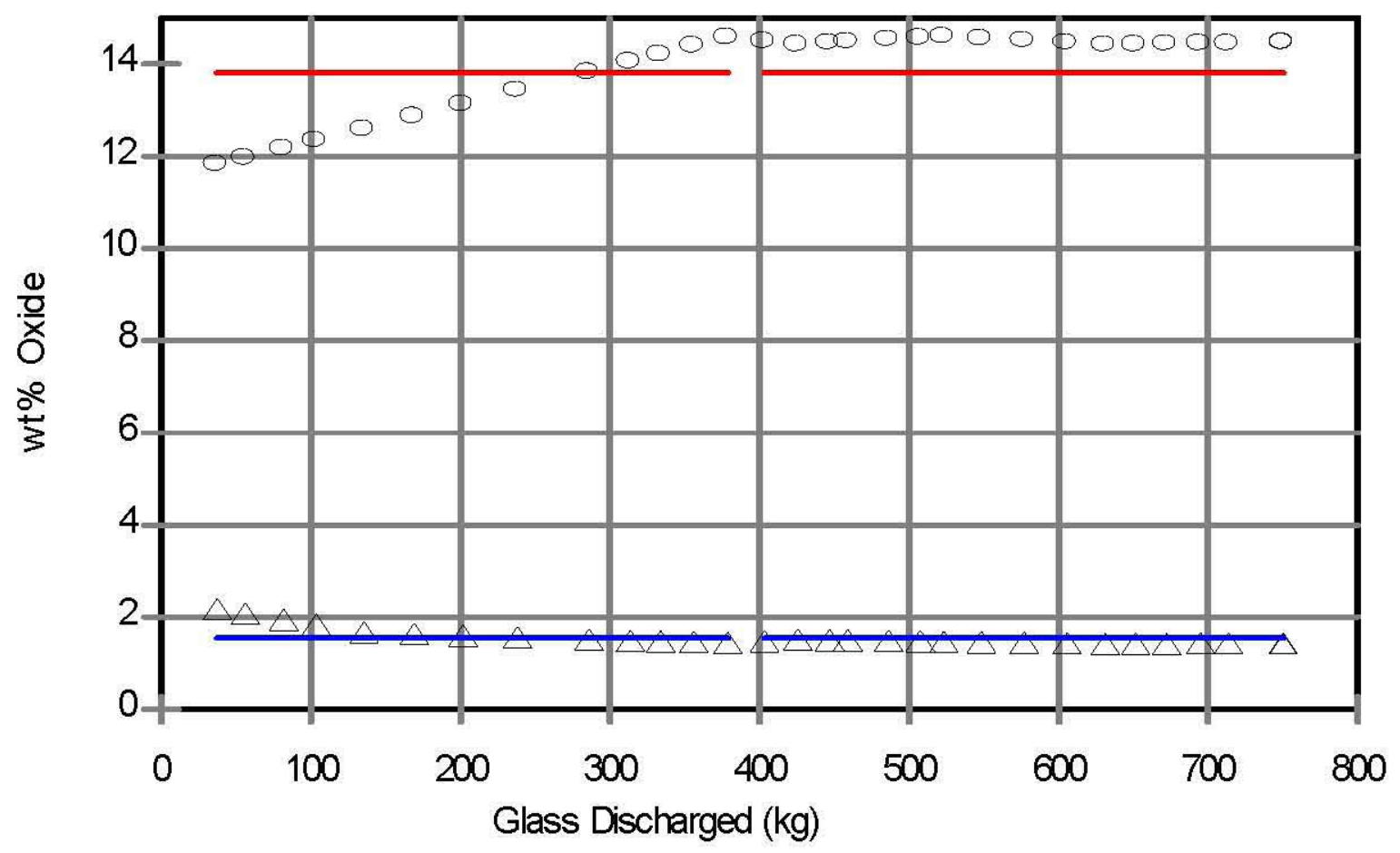

- BMeasured $\longrightarrow$ BTarget $\Delta$ Li Measured $\longrightarrow$ LiTarget

Figure 4.2. DM100 product and target glass compositions determined by DCP-AES. 
The Catholic Univer sity of America Vitrecus State Laboratory
Melt Rate Enhancement for High Aluminum HLW Glass Formulations Final Report, VSL-08R13601, Rev. O

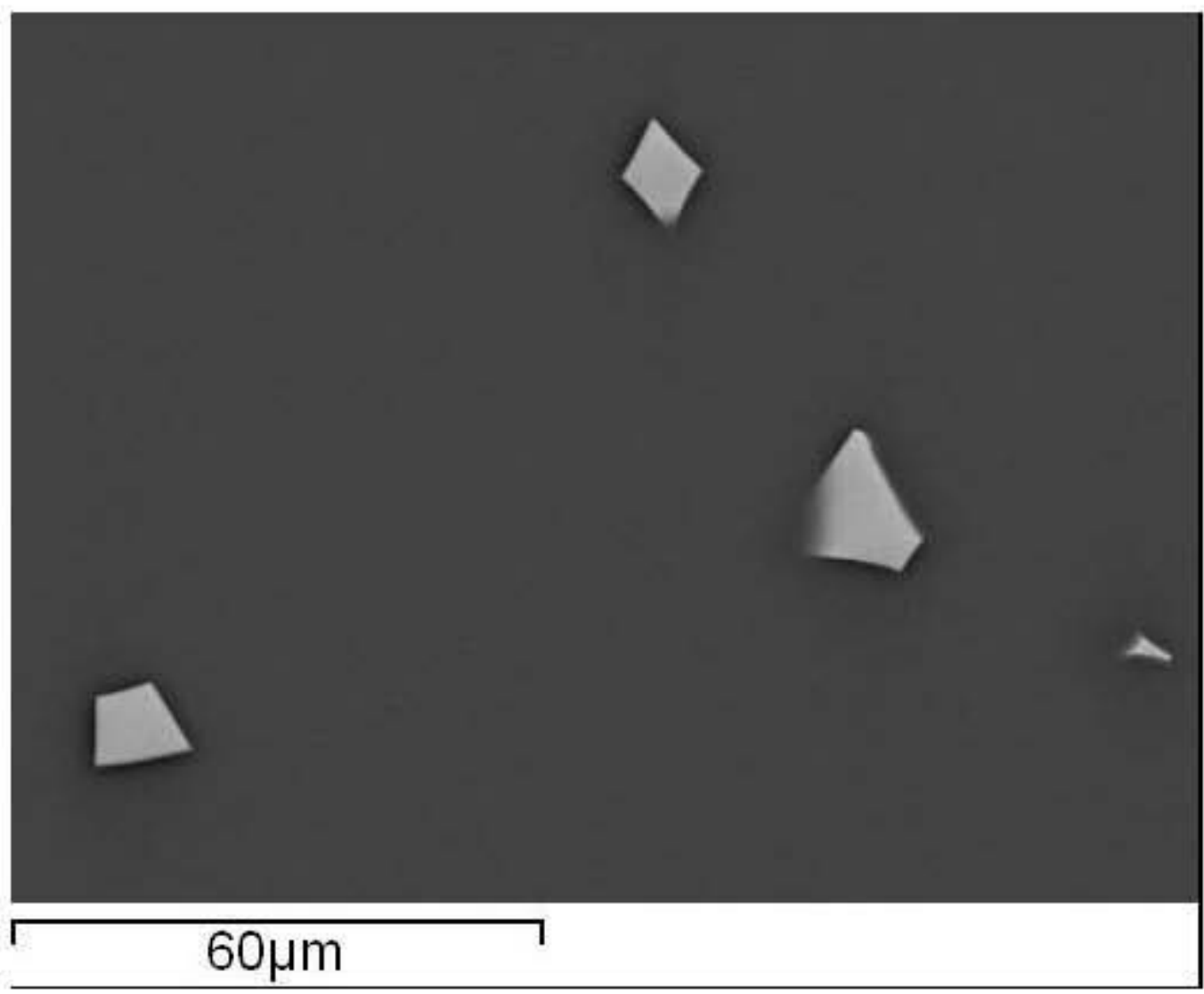

Figure 4.3. SEM micrograph of Cr-Ni-Mn iron spinels in glass from test with optimized bubbling. 
The Catholic Univer sity of America Vitrecus State Laboratory
Melt Rate Enhancement for High Aluminum HLW Glass Formulations Final Report, VSL-08R1360-1, Rev. 0

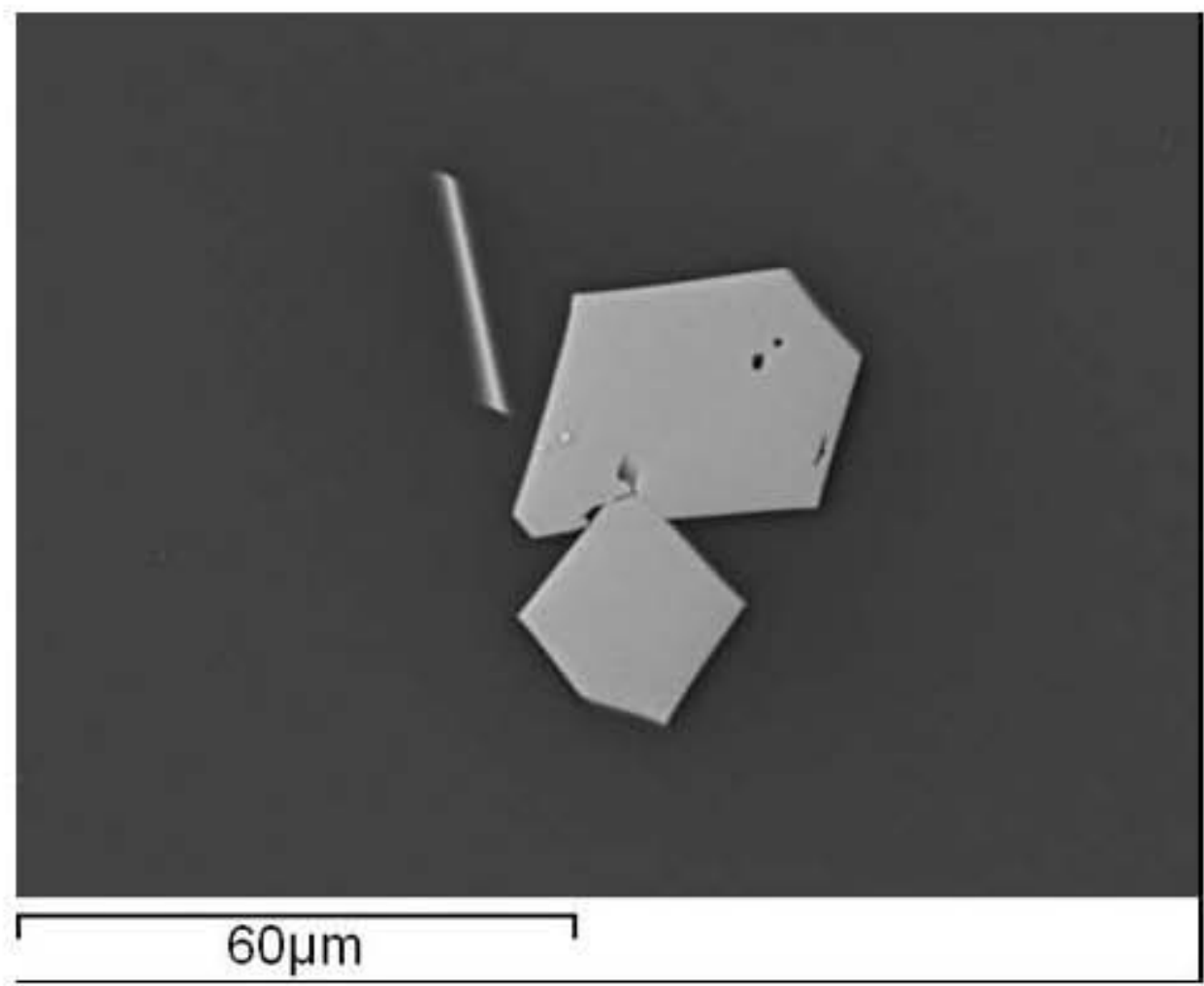

Figure 4.4.a. SEM micrograph of larger Ni-Mn iron spinels in glass from test with fixed bubbling. 
The Catholic University of America Vitrecus State Laboratory
Melt Rate Enhancement for High Aluminum HLW Glass Formulations Final Report, VSL-08R1360-1, Rev. 0

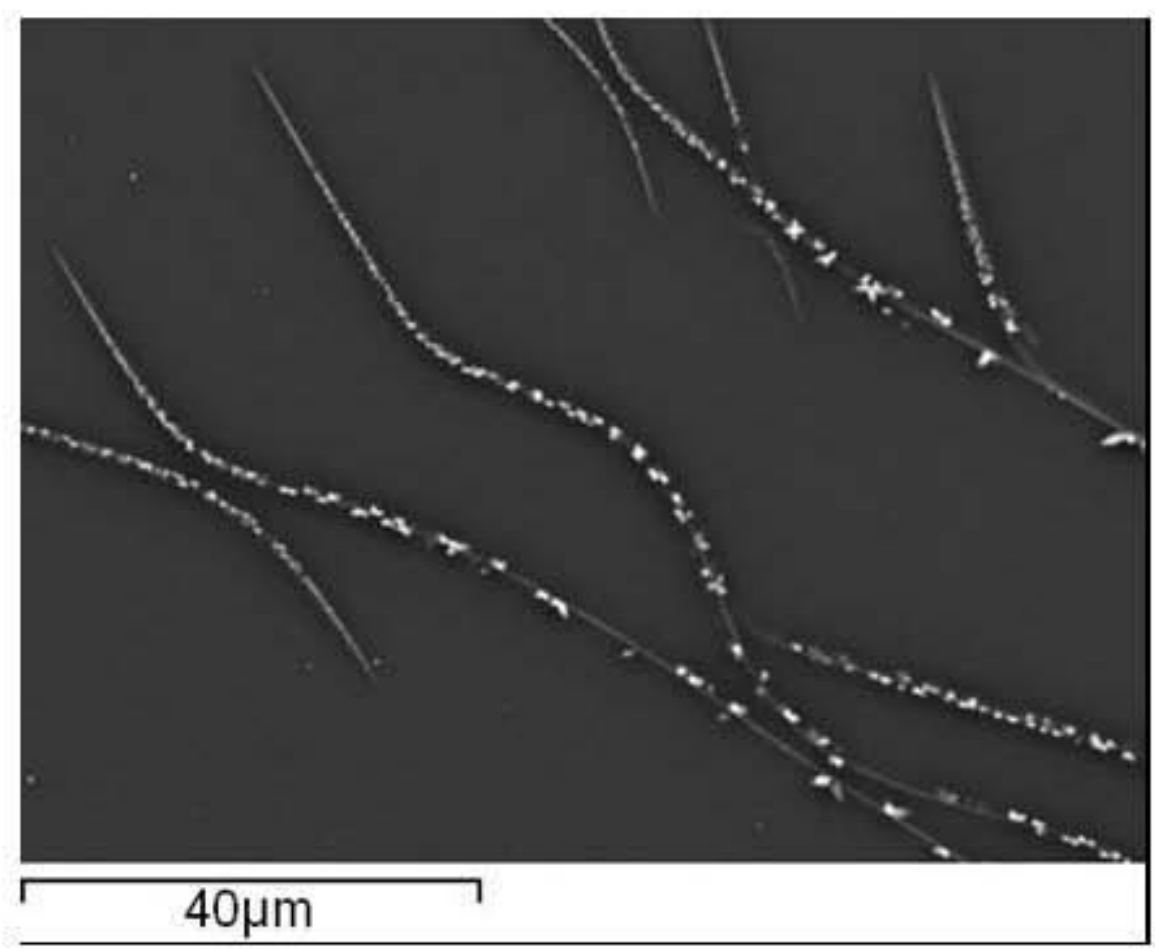

Figure 4.4.b. SEM micrograph of sm aller $\mathrm{Ni}-\mathrm{Mn}$ iron spinels in glass from test with fixed bubbling. 
The Catholic University of America Vitreous State Laboratory
Melt Rate Enhancement for High Aluminum HLW Glass Formulations

Final Report, VSL-08R1360-1, Rev. 0

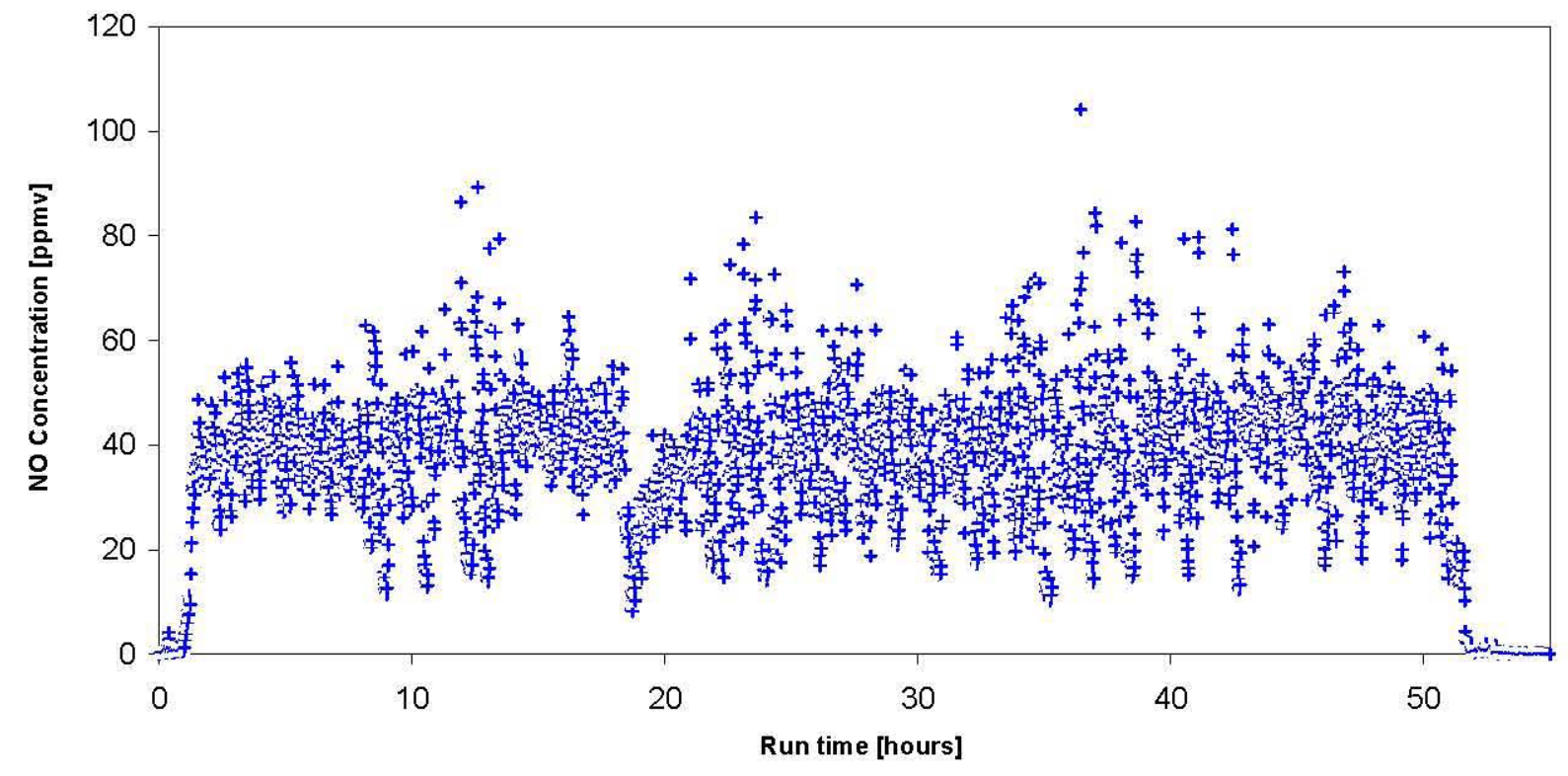

Figure 5.1. FTIR monitored NO emissions during tests with fixed bubbling. 
The Catholic University of America Vitreous State Laboratory
Melt Rate Enhancement for High Aluminum HLW Glass Formulations

Final Report, VSL-08R1360-1, Rev. 0

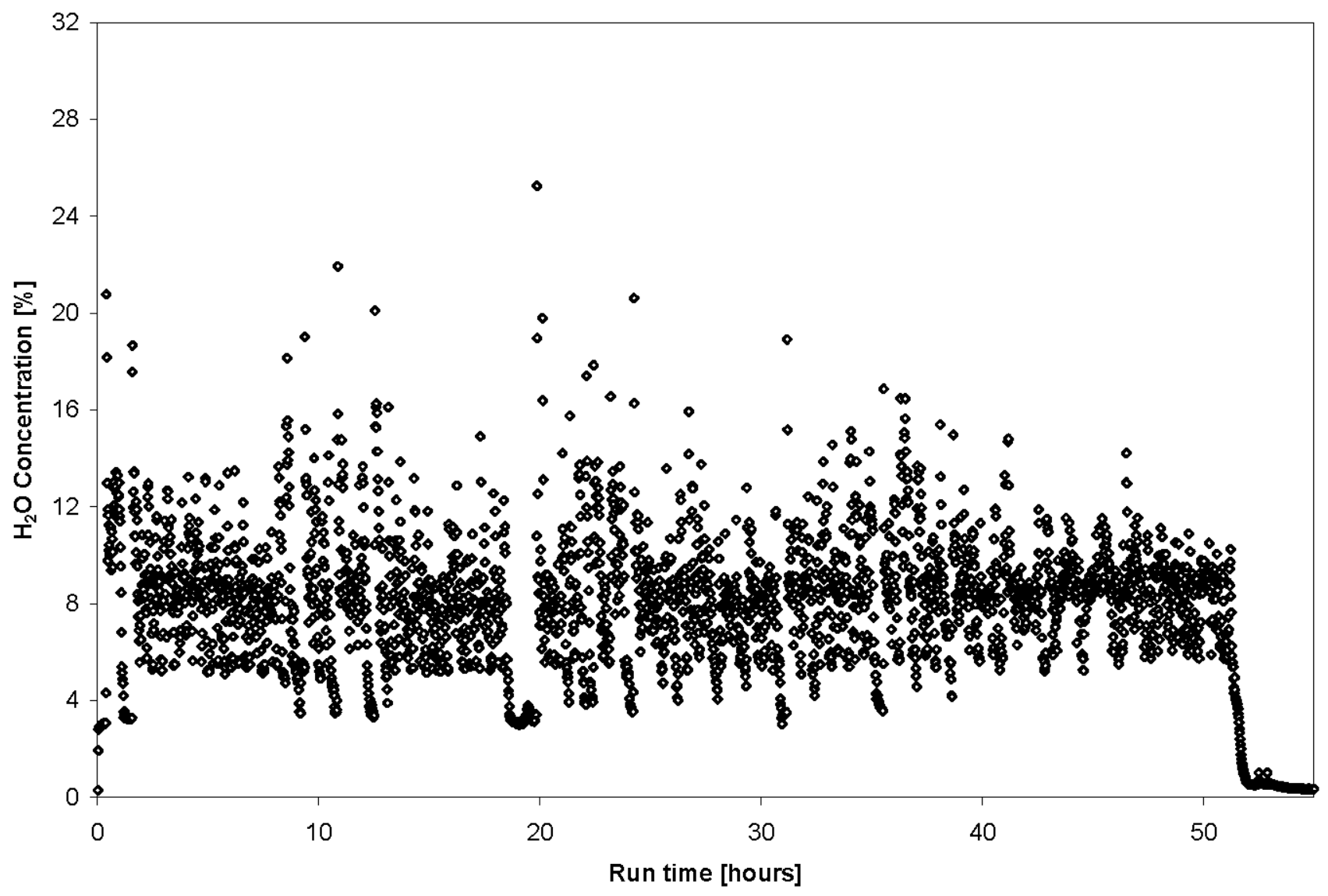

Figure 5.2. FTIR monitored water content of exhaust during tests with fixed bubbling. 